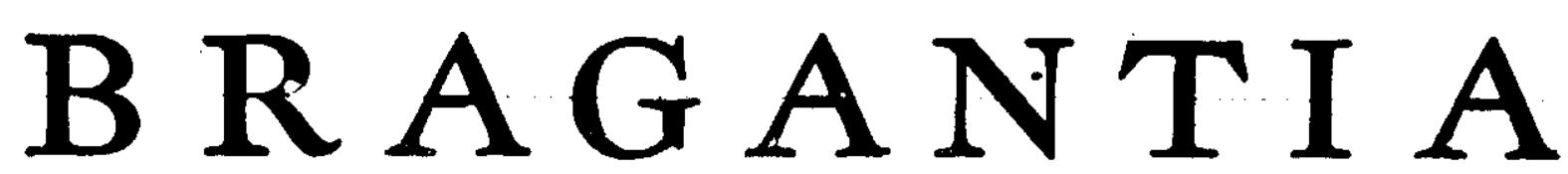

Boletim Técnico da Divisão de Experimentação e Pesquisas I N S T I T UTO A G R O NÔ M I CO

\begin{tabular}{lll}
\hline \hline Vol. 6 & Campinas, Outubro de 1946 & N. ${ }^{\circ} 10$ \\
\hline \hline
\end{tabular}

\title{
LIMITES UNILATERAIS E BILATERAIS NA ANÁLISE ESTATÍSTICA
}

INTRODUÇÃO

F. G. Brieger $\left(^{*}\right)$

\section{$\boldsymbol{O}$ conceito do desvio relativo e as distribuições do acaso}

$\mathrm{O}$ princípio básico da análise estatística consiste em resolver se um desvio, isto é, a diferença entre um valor experimentalmente obtido e o valor ideal correspondente, pode ser atribuído ao simples efeito das causas acidentais ou às consequências de causas sistemáticas. Para decisão desta alternativa, devemos dar dois passos preparatórios: em primeiro lugar, temos que transformar o valor do desvio de uma quantidade com uma denominação como centímetros, gramas, etc., em uma quantidade sem denominação ; em segundo lugar, devemos determinar qual a distribuição de acaso que deve ser utilizada para a comparação.

Definimos o desvio relativo como o quociente entre o desvio e o seu êrro "standard", devendo-se ainda distinguir dois casos diferentes: o desvio simples e o desvio composto (Brieger, 4). Se quisermos analisar desvios isolados, usaremos o desvio relativo simples que é o quociente de um só desvio dividido pelo êrro "standard". Se quisermos, porém, analisar simultâneamente vários desvios, devemos primeiramente reuní-los numa única estimativa, usando para isso a raiz quadrada da soma dos quadrados dos desvios, dividida pelo número de desvios livremente variáveis. Dividindo êste têrmo, pelo êrro "standard" correspondente, obteremos o que chamamos o desvio relativo composto.

$\mathrm{O}$ caso mais comum é a análise dos desvios de um número de variáveis $\mathbf{v}$ em relação à sua média aritmética $\overline{\mathbf{v}}$; neste caso podemos escrever as fórmulas do modo seguinte:

Desvio relativo simples : $\overline{\mathrm{D}}=\frac{\mathrm{v}-\overline{\mathrm{v}}}{\sigma}$

Desvio relativo composto : $\mathrm{D}=\sqrt{\frac{\frac{\sum(\mathrm{v}-\bar{v})^{2}}{\mathrm{n} 1}}{\sigma_{0}}}$ ou então $\mathrm{D}=\frac{\sigma_{1}}{\sigma_{2}}$

$\left(^{*}\right)$ Catedrático contratado da Cadeira de Cito-Genética da Escola Superior de Agricultura "Luiz de Queiroz". 
Todos os desvios são caraterizados por dois números correspondentes de graus de liberdade, um do divisor e outro do dividendo ; êles indicam de quantos valores livremente variáveis foram calculadas as componentes do desvio relativo. Usaremos para o grau de liberdade do dividendo o símbolo n1 e para o do divisor o símbolo n2, empregando ao mesmo tempo para os números totais os símbolos N1 e N2 $\left(^{*}\right)$.

As distribuições de acaśo podemos classificar de acôrdo com as suas fórmulas de definição matemática, denominando-se os quatro tipos principais pelos nomes de seus descobridores. Como explicamos em outro lugar (Brieger, 4), êstes autores usaram as distribuições em têrmos matemáticos diversos, para servirem em testes estatísticos especiais, de modo que as fórmulas dadas na literatura não deixam aparecer a homologia matemática das mesmas. Na publicação citada evitamos esta diversidade do formulário matemático.

Devemos distinguir nas fórmulas duas componentes: uma que é constante para cada distribuição e que depende dos graus de liberdade $\mathrm{n} 1$ e $\mathrm{n} 2$ do desvio relativo, e outra que depende do valor de desvio relativo próprio. As frequências y de qualquer valor do desvio relativo $\mathbf{D}$ podem ser determinadas pelas fórmulas seguintes:

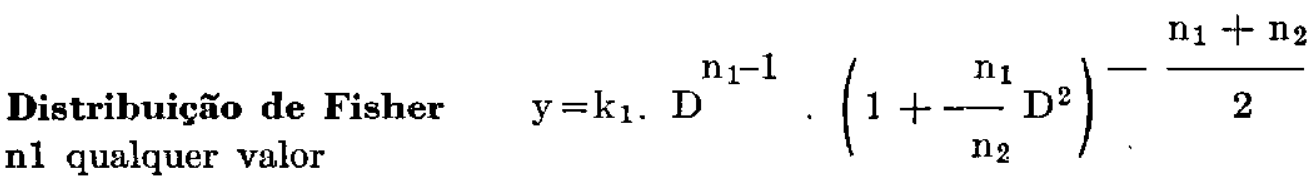

n2 qualquer valor

$$
\mathrm{k}_{1}=\frac{\frac{\mathrm{n}_{1}+\mathrm{n}_{2}-2}{2} !}{\frac{\mathrm{n}_{1}-2}{2} ! \frac{\mathrm{n}_{2}-2}{2} !} \cdot 2 \cdot\left(\frac{\mathrm{n}_{1}}{\mathrm{n}_{2}}\right)^{\frac{\mathrm{n}_{1}}{2}}
$$$$
y=k_{2} \cdot D^{n_{1}-1} \cdot e^{-\frac{n_{1}}{2} D^{2}}
$$

Distribuição de

$\mathrm{n} 2$ = infinito

$$
\begin{aligned}
& \frac{\mathrm{n}_{1}}{2} \\
& \mathrm{k}_{2}=\frac{\mathrm{n}_{1}}{\frac{\mathrm{n}_{1}-2}{2} ! \frac{\mathrm{n}_{1}-2}{2} !}
\end{aligned}
$$

$\left(^{*}\right)$ Temos usado, em outras publicações, os têrmos nfl e nf2 para indicar os graus de liberdade, mas o emprêgo dêstes têrmos em fórmulas mais complicadas, causa, não sòmente dificuldade na impressão, mas é ainda, às vêzes, a razão de confusões nas fórmulas, pois o têrmo nf pode ser interpretado como um produto $\mathbf{n}$ vêzes f. Assim, estamos usando agora, para o número de variáveis, letras capitais $\mathrm{N}$, M, etc. e as letras minúsculas correspondentes, com ou sem o sufixo $\mathbf{f}$, para os graus de liberdade. 
Distribuição de Student $y=k_{3} \cdot\left(1+\frac{1}{n_{2}} D^{2}\right)$
$n 1=1$
$n 2=$ qualquer valor

$$
\mathrm{k}_{3}=\frac{\frac{\mathrm{n}_{2}-1}{2} \mid}{\frac{\mathrm{n}_{2}-2}{2} \mid \sqrt{\mathrm{n}_{2} \pi}}
$$

Distribuição de Gauss

$\mathrm{n} 1=1$

$\mathrm{n} 2=$ infinito

$$
\mathrm{y}=\mathrm{k}_{4} \cdot \mathrm{e}^{-\frac{1}{2} \mathrm{D}^{2}}
$$$$
k_{4}=\frac{1}{\sqrt{2 \pi}}
$$

Como já explicamos com bastante detalhe na publicação citada (1), as relações matemáticas dêstes quatro tipos de distribuições, limitar-nosemos a citar aqui apenas algumas das conclusões mais importantes :

1) As distribuições de Pearson e a de Gauss são os casos limitantes para aquelas de Fisher e de Student, sempre que o valor de grau de liberdade n2 se torne tão grande que possa ser considerado como pràticamente igual ao infinito.

2) Quando nas distribuições de Fisher e Pearson o grau de liberdade n1 fica igual a um, elas são idênticas a uma das metades das distribuições de Student, com o mesmo valor de $\mathrm{n} 2$, ou de Gauss.

3) As distribuições de Student e Gauss (fig. 1), que se estendem desde valores de $D$ igual a rrenos infinito até mais infinito, são simétricas, tendo o seu máximo e centro na abcissa $\mathrm{D}$ igual a zero. De outro lado, as distribuições de Fisher e Pearson (fig. 2) são assimétricas e vão de $\mathrm{D}$ igual a zero até mais infinito.

Estas últimas conclusões são ilustradas pelas figs. 1 e 2, nas quais reproduzimos as distribuições de Student para $n 1=1 / \mathrm{n} 2=10$ e aquela de Fisher para os mesmos graus de liberdade. Outras ilustrações gráficas constam do trabalho citado (Brieger, 4).

Para a denominação das distribuições usamos os nomes dos seus idealizadores, como já explicamos acima, apesar de que êstes usaram outras unidades da abcissa em vez do desvio relativo $\mathrm{D}$. Assim, na fórmula das distribuições idealizadas por Pearson, usa-se, em geral, como unidade da abcissa, o valor denominado $\mathrm{X}^{2}$, que é igual ao produto entre o quadrado do desvio relativo e o seu grau de liberdade n1. Empregamos o nome de Student, isto é, o pseudônimo do falecido estatístico inglês W. Gosset, uma vez que o seu verdadeiro nome é relativamente muito pouco conhecido. $\mathrm{O}$ que chamamos distribuição de Gauss, é comumente conhecida pelo têrmo "distribuição 


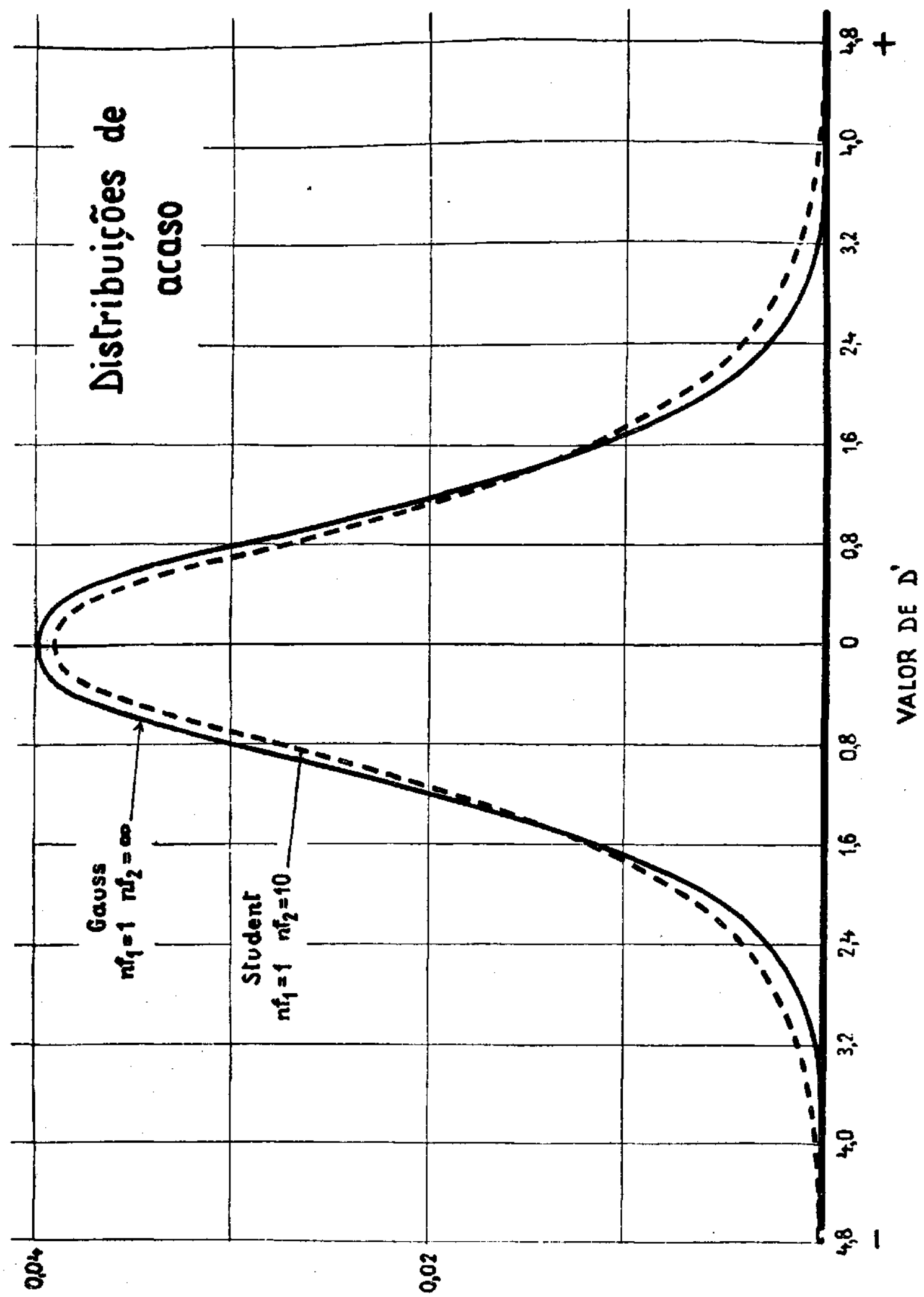

FREQUÊNCIA

Fig. 1 


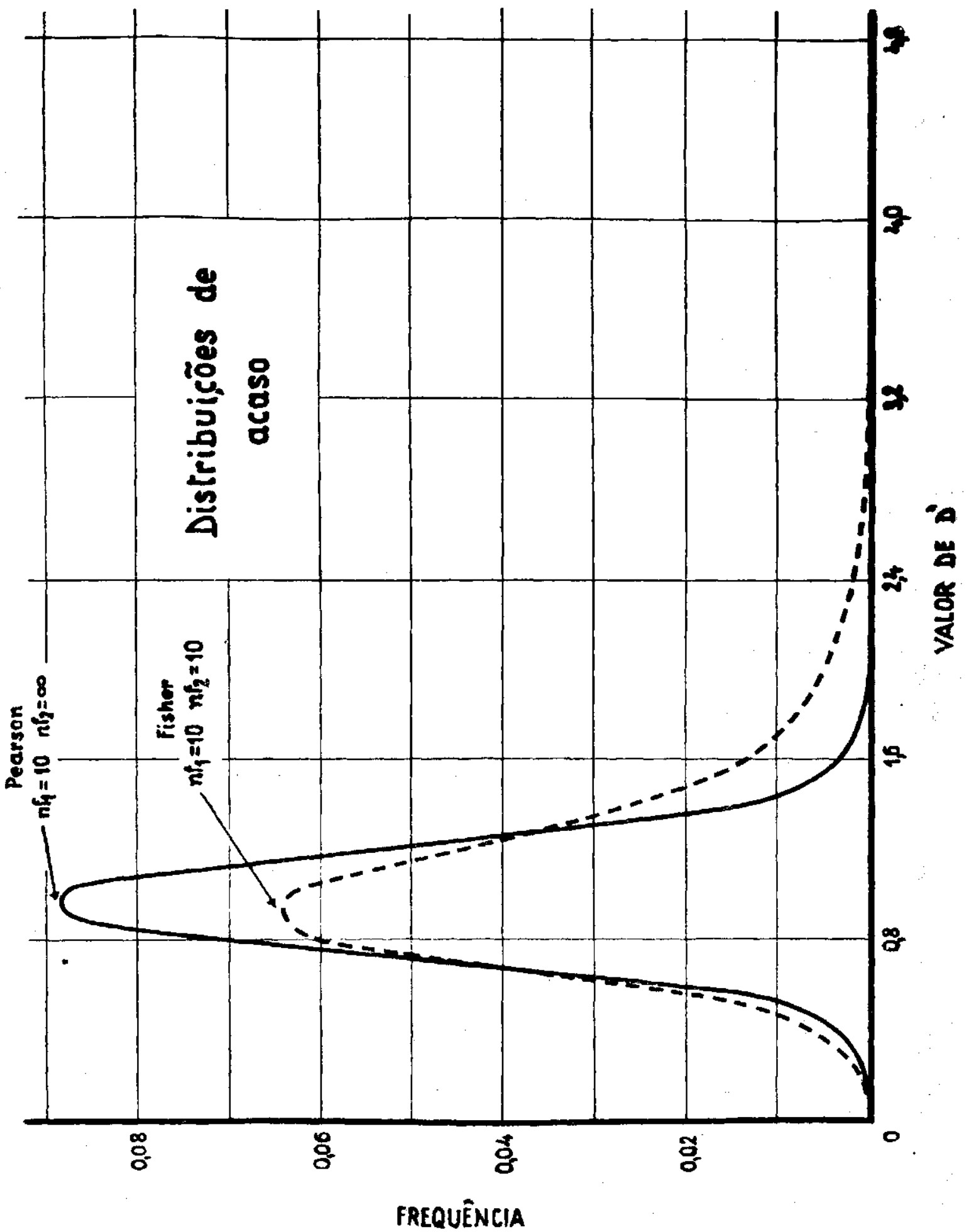

Fig. 2 
normal", porém é evidente que, com os conhecimentos muito mais aprofundados que hoje possuímos, não é mais possível considerar um caso tão especial como o "normal".

E evidente, de acôrdo com os seus respectivos graus de liberdade, que os desvios relativos simples seguem as distribuições de Student ou de Gauss e os desvios relativos compostos aquelas de Fisher ou Pearson.

A comparação dos desvios relativos determinados experimentalmente, com os valores esperados nas respectivas distribuições do acaso, pode ser feita por dois processos analíticos: 1) o teste das distribuições inteiras e 2) o teste das extremidades.

Para o teste da distribuição inteira devemos ter, no mínimo, 30 ou mais desvios relativos a serem analisados em conjunto. Agrupámo-los em intervalos de uma fração do seu êrro "standard" e determinamos a frequêneia observada dos desvios nestes intervalos; depois calculamos a frequência com que os desvios dêste tamanho eram esperados numa distribuição ideal ou do acaso, para, finalmente, comparar as frequências, observadas e esperadas, por um $\mathrm{X}^{2}$ teste. Devemos tomar as providências, pela reunião de intervalos, para que os valores da frequência esperada não fiquem menores do que 5, pois, em caso contrário $\left({ }^{*}\right)$, não se pode analisar com segurança estatística o quociente $\chi^{2}=\frac{\text { (f.obs. }- \text { f.esp. })^{2}}{\text { f.esp. }}$.

O teste das extremidades, que representa o assunto principal dêste trabalho, pode ser sempre aplicado. Ele será discutido detalhadamente nos capítulos seguintes.

\section{CONSIDERAÇÕES TEÓRICAS SÔBRE OS LIMITES E O SEU CALCULO}

\section{O princípio básico de teste das extremidades}

As curvas das distribuições de acaso apresentam um máximo, aproximando-se extremidades assimptòticamente à sua base, isto é, ao eixo das abcissas. Uma vez que usamos as frequências dos desvios relativos como ordenadas, esta redução da altura das curvas significa que as frequências teóricas para valores extremos do desvio relativo, em ambas as extremidades da curva, se tornam cada vez menores. Elas chegam a ser tão pcquenas que o aparecimento dos respectivos desvios já deve ser considerado como bastante improvável. Se, apesar disso, num experimento concreto, aparecerem desvios relativos muito extremos podemos concluir que o seu aparecimento nada mais tem a ver com a distribuição ou variação do acaso, mas que causas especiais, e não de acaso, são responsáveis pelo seu aparecimento.

Escolhendo um valor do desvio relativo como limite entre os desvios prováveis e improváveis, podemos calcular o valor da ordenada correspondente e assim separar uma área nas extremidades da distribuição do

$\left(^{*}\right)$ Num trabalho em impressão nos Anais da Escola S. A. "Luiz de Queiroz" daremos uma tabela para os casos nos quais a frequência esperada é menor do que 5 . 
acaso do resto da curva. Uma vez que as ordenadas das curvas são as frequências dos respectivos desvios relativos, as áreas separadas representam a soma das frequências de todos os desvios fora do valor escolhido como limite.

As figs. 3 e 4 explicam esta situação mais claramente do que muitas palavras. As áreas cortadas nas extremidades e coloridas de preto correspondem sempre a 5\% da área total das distribuições representadas. As figuras demonstram dois pontos importantes:

a) Em primeiro lugar, podemos cortar uma área em ambos os lados da curva : "limites bilaterais", ou apenas em uma ou outra extremidade : "limites unilaterais";

b) Em segundo lugar, devemos notar uma diferença entre as distribuições simétricas de Student e de Gauss de um lado (fig. 3), e as distribuiçóes assimétricas de Fisher e de Pearson de outro (fig. 4). Nas primeiras, os limites dos desvios relativos em extremidades opostas são de valor numérico idêntico, sendo apenas de sinal oposto. Nas distribuições de Fisher e Pearson, os limites têm sempre valores diferentes, sendo ou maior do que um ou então frações menores do que um.

Preparando as tábuas dos limites a serem usados em testes estatísticos, devemos distinguir claramente entre os limites de probabilidade também chamados limites de precisão ou soma das frequências, isto é, a área que queremos destacar nas extremidades das distribuições, e os limites dos desvios relativos, que são as abcissas, sôbre as quais devemos levantar as ordenadas que separam as áreas nas extremidades do resto da distribuição.

O cálculo dos limites do desvio tem que ser feito depois de estabelecido o que nós consideramos limite de probabilidade. Devemos assim definir um valor tão pequeno de probabilidade, de modo que possamos dizer que será bastante improvável que um acontecimento, tão raramente esperado, fôsse encontrado na realidade.

\section{Os limites de probabilidade ou de precisão}

Estudando a literatura estatística dos últimos 40 anos, podemos verificar que são bastante divergentes os limites de probabilidade adotados pelos diferentes autores. Por exemplo, foi considerado na literatura angloamericana, como suficiente, um limite de $5 \%$, que corresponde, na distribuição de Gauss, a valores de desvios cêrca de 3 vêzes maior que o êrro provável. Na literatura do continente europeu recomendou-se um limite de cêrca de $1 \%$, correspondente a desvios três vêzes maiores do que o êrro "standard" da distribuição.

O estabelecimento dos limites de probabilidade depende de dois argumentos, um de natureza estatística e outro de ordem psicológica. Assim, devemos frizar, em primeiro lugar, que o limite escolhido depende do número de observações que tomarmos em consideração em conjunto. Suponhamos que estudamos a variação da produção em milho; uma produção, por planta, muito elevada, esperada com uma probabilidade de 1 em 20 , deve ser encontrada em cada 20 indivíduos uma vez; em 100 indivíduos 


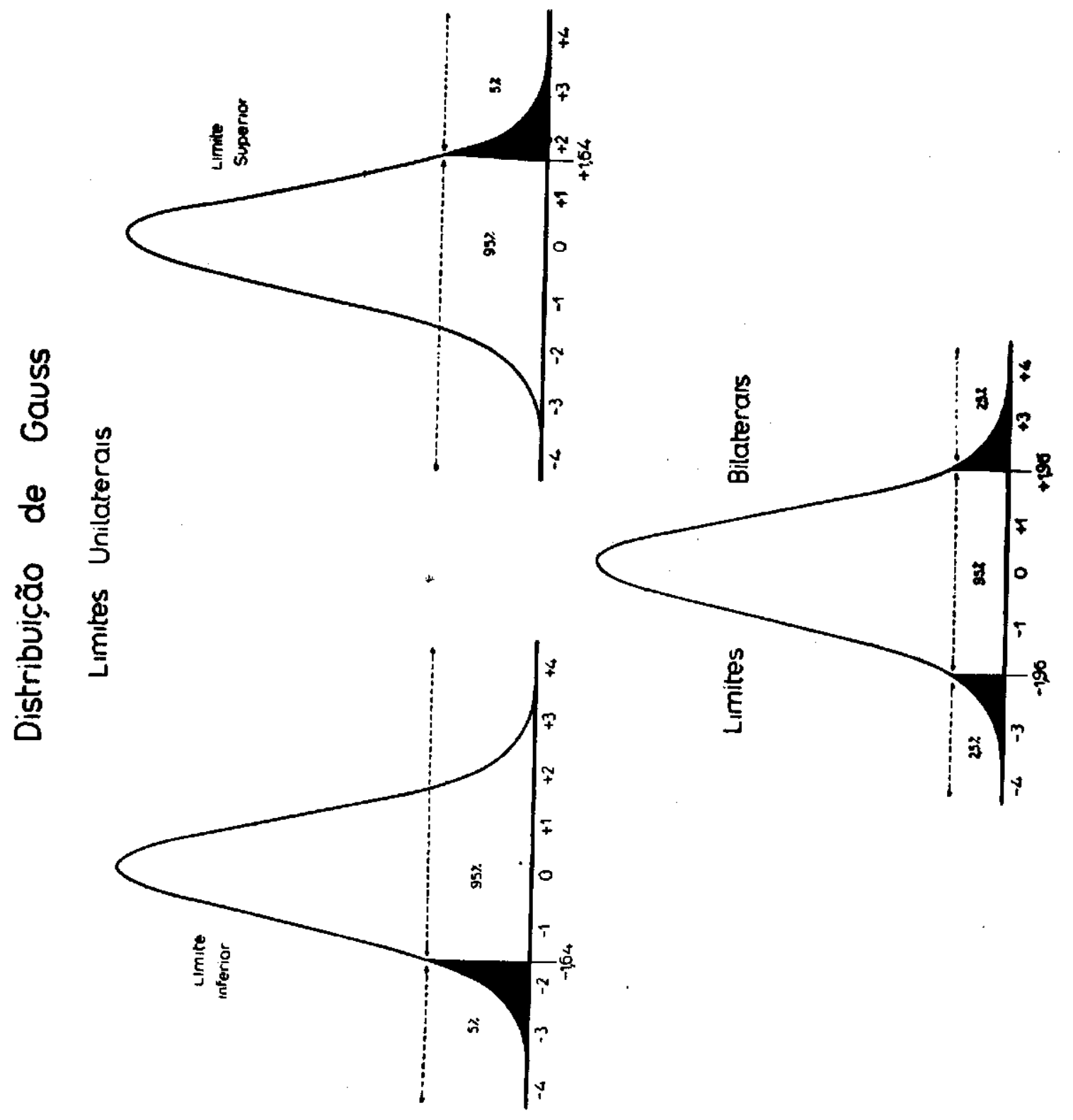

Fig. 3 


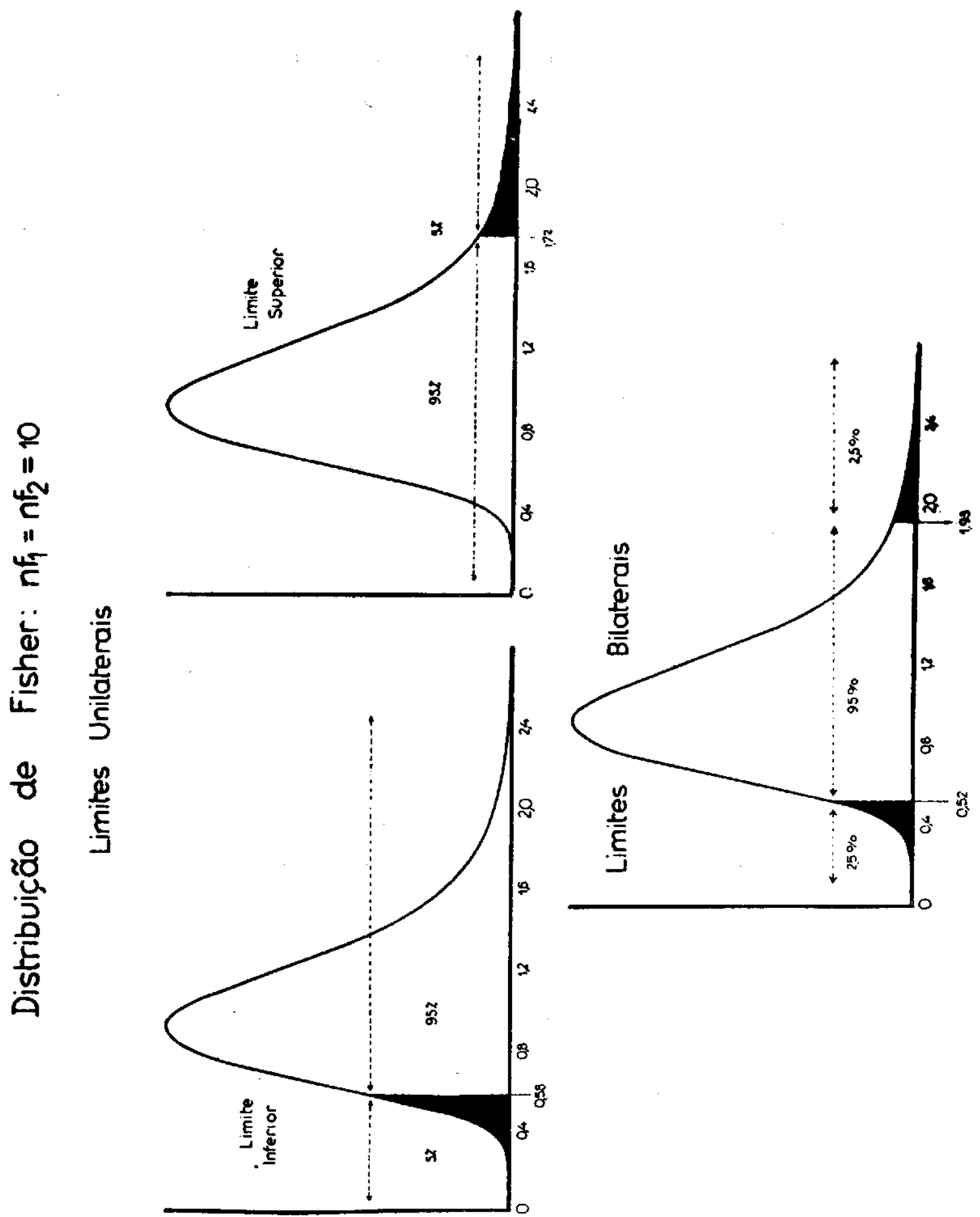

Fin 4 
Variaçâo do comprimento da folha em ficus
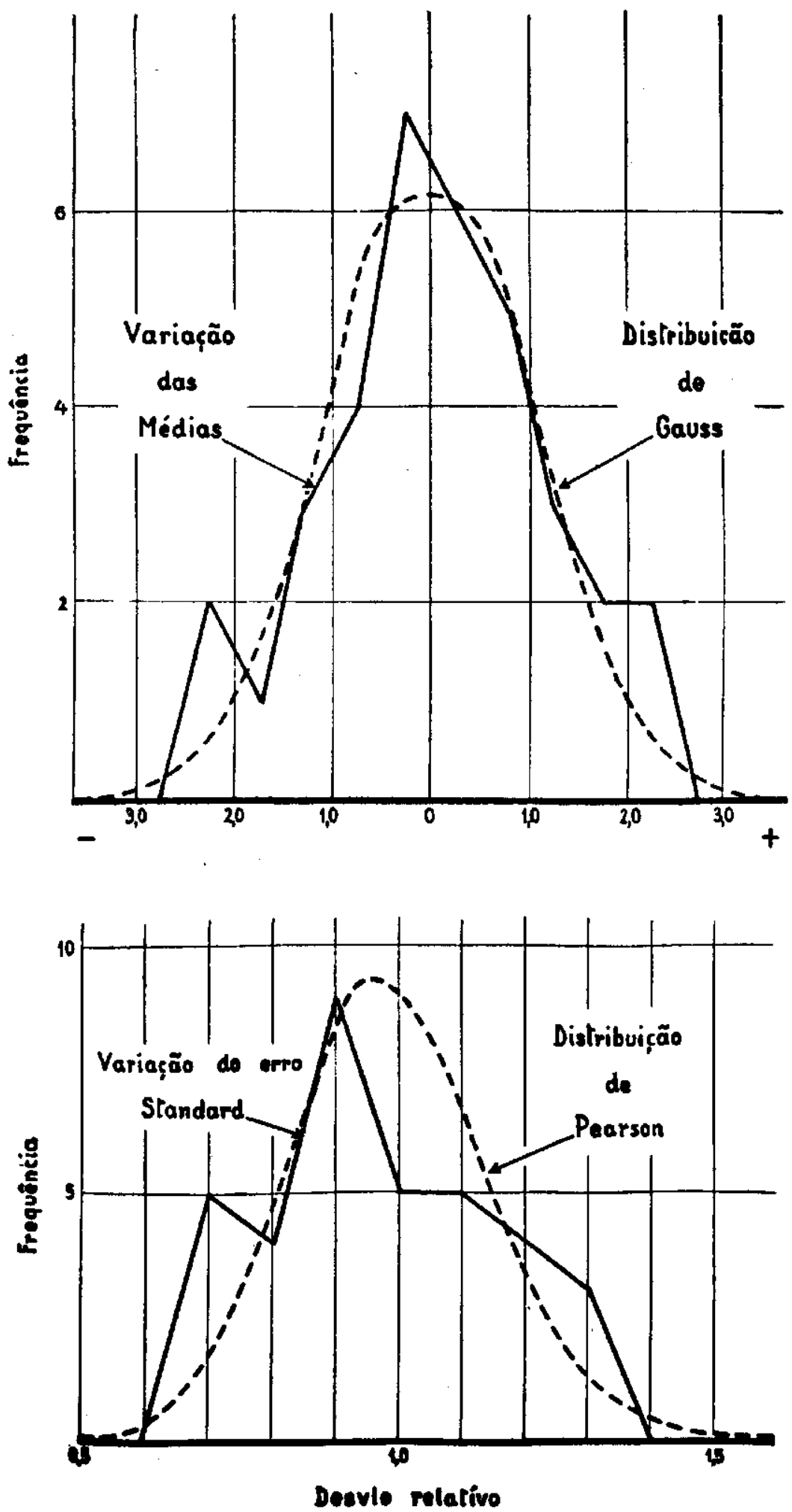

Fig. 5 
Variação da altura da espiga do milho
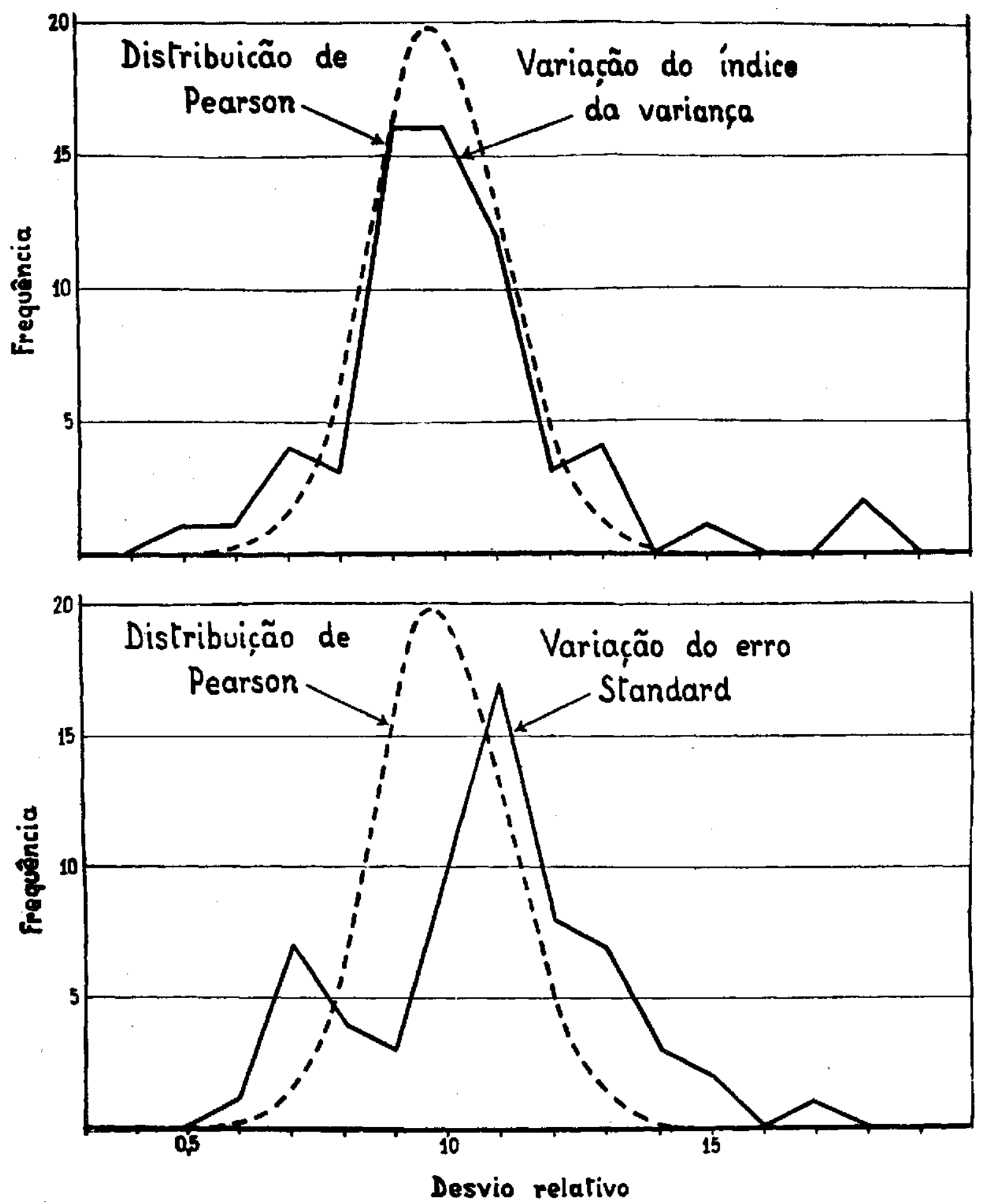

Fig. 6 
poderíamos esperar já 5 indivíduos desta natureza e em 5 indivíduos estudados, nenhum. Podemos, assim, decidir que acontecimentos com uma frequência de 1 em 20 , ou $5 \%$, podem ser considerados improváveis num total de 5 casos estudados e muito comum quando temos um conjunto de 100 casos.

Este exemplo demonstra claramente que os limites entre o provável e o improvável são uma função do número de observaçz̃es que se tem tomado em consideração em conjunto, e devemos procurar uma fórmula matemática para dar a esta relação uma forma concreta.

Outra dificuldade no estabelecimento dos limites de probabilidade é uma consequência do julgamento subjetivo. Uma "chance" que pessimistas já não mais consideram como de qualquer interêsse, um otimista vai talvez achar muito boa, e assim é muito dif́cil indicar um valor certo que separe o provável do improvável. Por esta razão introduzimos o conceito da região da dúvida (Brieger 1, 2) intercalada entre o provável e o improvável. Devemos fixar assim dois limites, determinando quais as probabilidades que são tão baixas que tornam um acontecimento improvável e quais as probabilidades tão altas de modo que tornam o acontecimento bastante provável.

Se encontrarmos num experimento um valor ou um acontecimento, mesmo que a sua probabilidade seja menor do que o limite de improbabilidade, podemos considerar justificada a nossa conclusão de que foi êle causado por fatôres especiais. Valores ou acontecimentos, que já foram considerados de antemão como prováveis, podemos atribuir a simples efeitos de causas acidentais, sendo por isso sem interêsse. Finalmente, se verificarmos num experimento que a frequência de um valor na distribuição do acaso caiu justamente na região da dúvida, não podemos resolver se êste valor foi causado pela variação do acaso ou por causas sistemáticas. Qưando se trata de um problema de muita importância, teremos que repetir o experimento, em condições mais rigorosas.

Baseados nestas considerações podemos formular, finalmente, uma relação matemática e empírica para a determinação dos limites de probabilidade e de improbabilidade, a qual aplicamos durante cêrca de dez anos com resultados sempre satisfatórios. Os limites assim calculados correspondem, de um modo geral, aos limites aplicados sem justificação por vários autores, como, por exemplo, o limite de $5 \%$ na experimentação agrícola e o limite de $1 \%$ na experimentação genética.

Podemos definir, sendo $\mathbf{N}$ o número de observações que estudamos em conjunto :

Improbabilidade :

Limite de improbabilidade :

$\mathrm{P}$ menor do que $1: 10 \mathrm{~N}$

Região de dúvidas:

Limite de probabilidade :

Região de provável :

$\mathrm{P}=1: 10 \mathrm{~N}$

$\mathrm{P}$ entre $1: 10 \mathrm{~N}$ e $1: 5 \mathrm{~N}$

$\mathrm{P}=1: 5 \mathrm{~N}$

$\mathrm{P}$ maior do que $1: 5 \mathrm{~N}$

Lembramos que a determinação dos limites de probabilidade $\mathrm{P}$ precede o cálculo dos valores do desvio relativo $\mathrm{D}$, isto 6 , das abcissas, nos quais 
devemos colocar a ordenada, que separa nas extremidades das curvas uma área igual a $\mathrm{P}$. Assim, deveríamos calcular, para qualquer valor de $\mathrm{N}$ e para o valor de $\mathbf{P}$ escolhido, o valor do desvio relativo correspondente, o que exige sempre um trabalho tão grande, que a sua execução se torna impraticável. Torna-se necessário usar tábuas prèviamente elaboradas e que podem naturalmente conter apenas certos valores escolhidos, os quais são convencionalmente os valores dos desvios que separam áreas de 5\%, $1 \%$ e $1 \%$ nas extremidades da área restante e correspondendo assim aos limites de $5 \%, 1 \%$ e $1 \%$ probabilidade. A refação dêstes limites, que nós chamamos limites convencionais, e dos limites calculados, segundo as fórmulas, também consta da tábua XI.

Pode parecer, a primeira vista, estranho que os limites convencionais de $5 \%$ e $1 \%$ e $0,1 \%$ não seguem nenhuma progressão, seja aritmética, seja geométrica. Devemos, porém, lembrar que a sequência dêstes limites de probabilidade é menos importante do que aquela dos valores correspondentes do desvio relativo. Uma inspeção das tábuas demonstra que esta, por sua vez, segue uma relação simples : o valor do desvio relativo no $1 \%$ limite de probabilidade é aproximadamente no meio entre os outros dois valores. Assim, temos, por exemplo, para a distribuição de Gauss :

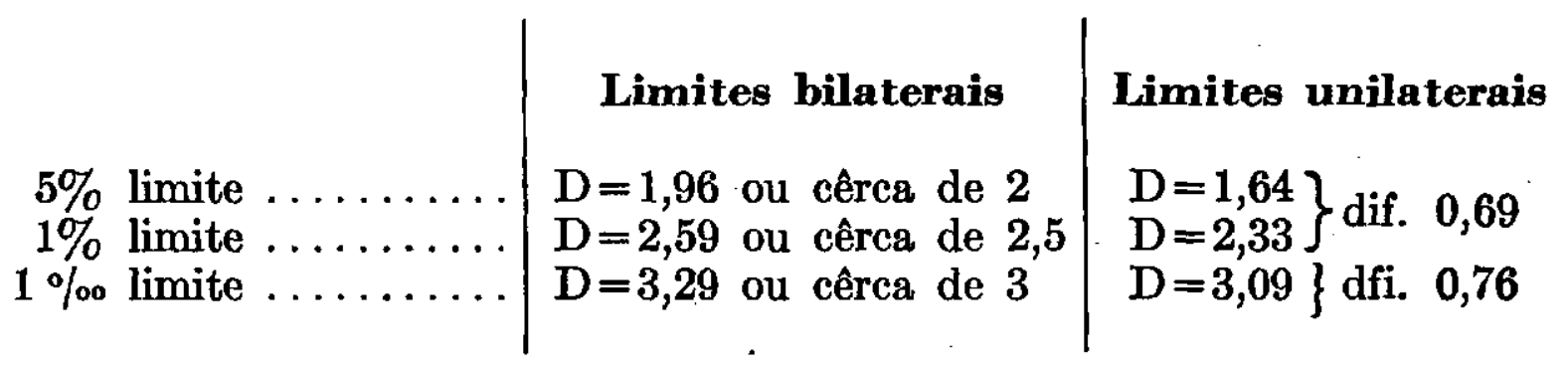

Os valores do desvio relativo no $1 \%$ limite são assim quase iguais à média dos dois outros valores : 2,59 em comparação com $(1,96+3,29)$ : $2=2,68$ e 2,33 em comparação com $(1,64+3,09): 2=2,37$.

\section{O cálculo dos limites dos desvios relativos}

Para a determinação dos valores limitantes dos desvios relativos é necessário calcular a área, tanto parcial como integral, das respectivas distribuições do acaso. Para êste fim, podemos aplicar processos matemáticos, mais ou menos complicados, de integração. Por exemplo, as fórmulas de integração para a distribuição de Gauss e para aquelas de Pearson são dadas por muitos autores e constam do tratado de Yule-Kendall (9).

Aplicamos sistemàticamente, para tôdas as distribuições, o seguinte processo : calculamos pelas fórmulas dadas acima (na página 2) as ordenadas $\mathbf{y}$ das curvas, para intervalos de um décimo do desvio relativo. As áreas correspondentes a cada um dêstes intervalos da abcissa terão então o valor de $\mathbf{Y}=\mathbf{0}, \mathbf{l y}$, e o total de tôdas as áreas $\mathbf{Y}$ será igual à unidade. Isto é, calculamos as ordenadas para as distribuiçóes do acaso com áreaunidade, sendo a unidade da abcissa um décimo do desvio relativo. Depois 
formamos sucessivamente as somas dos valores de $\mathrm{Y}$, começando numa extremidade da distribuição, até que esta soma fôsse justamente um pouco menor do que o limite de probabilidade aceito. Aplicando os princípios de interpolação proporcional, dividimos o próximo intervalo do desvio relativo na proporção entre a área dêste intervalo da abcissa e a diferença do limite de probabilidade e da soma já acumulada dos valores Y. Assim, obtivemos os centésimos e milésimos do valor do desvio relativo limitante para a área P. Apenaś quando necessário, executamos os cálculos para frações do desvio relativo menores do que um décimo.

Recalculamos por êste processo um número de valores limitantes das tábuas de Fisher and Yates (7) e verificamos que a concordância dos dados era sempre bem satisfatória. Havia sòmente divergências sem importância, de poucos centésimos, ou apenas de milésimos do valor do desvio relativo.

Determinamos um número suficiente de limites do desvio para uma primeira confeç̧ão de tábuas incompletas. Os valores restantes foram depois determinados por um processo de interpolação, algébrica, e esta interpolação foi em seguida confirmada ou corrigida pela verificação gráfica. Quando surgiram dúvidas neste trabalho de interpolação, recorremos ao cálculo direto dos limites pela soma das áreas por mais algumas distribuições.

Para descobrir possíveis erros de cálculo, determinamos não apenas as coordenadas y para as extremidades das curvas, mas também, na maioria das distribuiçбes, as ordenadas da curva inteira, verificando se a soma era igual à unidade e aceitando uma divergência dêste resultado apenas na sextra casa decimal, ou de uns poucos milionésimos.

Não é tècnicamente possível incluir em tábuas os três limites de probabilidade, de $5 \%, 1 \%$ e $1 \%$, para tôdas as combinaçóes de graus de liberdade, que possam porventura aparecer em experimentos. Os graus de liberdade, que constam das tábuas, foram escolhidos de tal modo que todos os valores que faltam podem ser determinados fàcilmente por uma fórmula simples de interpolação e com uma aproximação suficiente. A fórmula que recomendamos poderá ser explicada do seguinte modo :

Desejando saber qual o limite de probabilidade $\mathrm{P}(\mathrm{x})$ para um grau de liberdade $n(x)$, que não consta das tábuas, procuramos primeiro os limites $D$ (a) e D (b) para os graus de liberdade a e b mais proximos ao $\mathbf{x}$ e que se encontram incluídos na tábua. Devendo fazer uma interpolação numa curva que difere bastante da linha reta, temos que introduzir um fator m para a interpolação curvilinear e que achamos nas tábuas auxiliares anexas (Tábua VI). Temos, assim, para a menor $\mathrm{x}$ menor $\mathrm{b}$ :

$$
\mathrm{D}(\mathrm{x}) \doteq \mathrm{D}(\mathrm{a})+[(\mathrm{D}(\mathrm{b})-\mathrm{D}(\mathrm{a})] \mathrm{m}
$$

Esta fórmula pode ser aplicada tanto quando n1 ou n2 não constam das tábuas, como também quando ambas têm que ser interpoladas. Explicamos o cálculo com a ajuda de alguns exemplos : 
EXEMPLOS DE INTERPOLAÇÃO NAS TABUAS DOS LIMITES

1) Qual é o $1 \%$ limite bilateral superior para $\mathrm{n} 1=22 ; \mathrm{n} 2=25$

a) $\mathrm{n} 1=20 ; \mathrm{n} 2=25 ; \mathrm{D}=1,75$

b) $\mathrm{n} 1=25 ; \mathrm{n} 2=25 ; \mathrm{D}=1,71$

Tábua VI A

$\mathrm{na}-\mathrm{nb}=5 ; \mathrm{nx}-\mathrm{na}=2 ; \mathrm{m}=0,61$

$\mathrm{D}(22 ; 25)=1,75+(1,71-1,75) .0,61$

$$
\begin{aligned}
& =1,75-0,04 \times 0,61 \\
& =1,75-0,0244=1,7256=1,73
\end{aligned}
$$

2) Qual é o $5 \%$ limite superior para $\mathrm{n} 1=67 ; \mathrm{n} 2=50$

Valores da tábua : a) $\mathrm{n} 1=50 ; \mathrm{n} 2=50 ; \mathrm{D}=1,62$

$$
\text { b) } \mathrm{n} 1=75 ; \mathrm{n} 2=50 ; \mathrm{D}=1,57\}
$$

$\mathrm{na}-\mathrm{nb}=25 ; \mathrm{nx}-\mathrm{na}=17=15+2 ; \mathrm{m}=0,78+0,13 \times 0,61=0,86$ $\mathrm{D}(67 ; 50)=1,62+(1,57-1,62) .0,86$

$$
\begin{aligned}
& =1,62-0,05-0,86 \\
& =1,62-0,0430=1,5770=1,58
\end{aligned}
$$

3) Qual é o $1 \%$ limite bilateral superior para $\mathrm{n} 1=17 ; \mathrm{n} 2=23$

A) Determinação do limite para $\mathrm{n} 1=17 ; \mathrm{n} 2=20$

a) $\mathrm{n} 1=15 ; \mathrm{n} 2=20 ; \mathrm{D}=1,60$

b) $\mathrm{n} 1=20 ; \mathrm{n} 2=20 ; \mathrm{D}=1,57$

$\mathrm{na}-\mathrm{nb}=5 ; \mathrm{nx}-\mathrm{na}=2 ; \mathrm{m} \cdot=0,61$

$\mathrm{D}(17 ; 20)=1,60+(1,57-1,60) .0,61$

$$
\begin{aligned}
& =1,60-0,03 \times 0,61 \\
& =1,60-0,0183=1,5817=1,58
\end{aligned}
$$

B) Determinação do limite para $\mathrm{n} 1=17 ; \mathrm{n} 2=25$

Valores da tábua:

$\left.\begin{array}{l}\text { a) } \mathrm{n} 1=15 ; \mathrm{n} 2=25 ; \mathrm{D}=1,55 \\ \text { b) } \mathrm{n} 2=20 ; \mathrm{n} 2=25 ; \mathrm{D}=1,52\end{array}\right\}$ Tábua VI A

$\mathrm{na}-\mathrm{nb}=5 ; \mathrm{nx}-\mathrm{na}=2 ; \mathrm{m}=0,61$

$\mathrm{D}(17 ; 25)=1,65+(1,52-1,55) .0,61$

$=1,55-0,03 \times 0,61$

$=1,55-0,0183=1,5317=1,53$

C) Determinação final para $n 1=17 ; \mathrm{n} 2=23$

a) $\mathrm{n} 1=17 ; \mathrm{n} 2=20 ; \mathrm{D}=1,5817$

b) $\mathrm{n} 1=17 ; \mathrm{n} 2=25 ; \mathrm{D}=1,5317$

$\mathrm{na}-\mathrm{nb}=5 ; \mathrm{nx}-\mathrm{na}=3 ; \mathrm{m}=0,78$

$\mathrm{D}(17 ; 23)=1,5817+(1,5317-1,5817) .0,78$

$=1,5817-0,0500 \times 0,78$

$=1,5817-0,0390=1,5427=1,54$ 


\section{O principio dos limites unilaterais e bilaterais}

Já mencionámos que o cálculo dos limites do desvio relativo pode ser feito com o fim de separar uma área numa das extremidades, ou também em ambas as extremidades da curva. Assim, quando queremos determinar as abcissas limitantes, correspondentes a limites de $5 \%$ de probabilidade, podemos escolher um valor de $\mathrm{D}$ que separa uma área de $\mathrm{P}=0,5$ ou $5 \%$ numa ou noutra extremidade : limites unilaterais ; ou então as abcissas que separam $2,5 \%$ numa e $2,5 \%$ na outra extremidade : limites bilaterais.

A fig. 3 explica gràficamente a diferença entre êstes dois tipos de limites para a distribuição de Gauss. Temos em baixo uma representação do limite de $5 \%$ bilateral, sendo o valor da abcissa limitante igual a $\mathrm{D}= \pm 1,96$. $O$ valor limitante para os limites de probabilidade unilaterais é naturalmente menor, sendo igual a $-1,64$ ou $+1,64$. Sendo a distribuição de Gauss simétrica, os dois limites unilaterais, isto e, o limite superior de $+1,64$ e o limite inferior de $-1,64$, são iguais, exceto quanto ao sinal.

$\mathrm{Na}$ fig. 4 representamos a mesma situação para a distribuição de Fisher, com $\mathrm{n} 1=\mathrm{n} 2=10$. Estas curvas são assimétricas, e, assim, os valores de limites inferiores e superiores são bastante diferentes. Para os limites bilaterais temos os valores de 0,52 e 1,93 e para os limites unilaterais, os valores 0,58 ou 1,72 .

Pıra as distribuições de Student, que são simétricas como aquela de Gauss, encontramos a mesma situação : os limites inferiores do desvio relativo e os limites superiores são iguais, exceto quanto ao sinal, que é negativo para os primeiros e positivo para os segundos. As distribuições de Pearson são assimétricas, e os limites inferiores e superiores têm valores diferentes, sendo um sempre menor do que um e outro maior. A significação dos limites unilaterais e bilaterais também é diferente para os dois grupos de distribuições.

Os desvios relativos que seguem as distribuiçz̃es de Student ou de Gauss podem ser positivos ou negativos. Se temos uma série de variações e queremos saber quais são significantemente maiores ou menores do que a média, devemos usar os limites bilaterais, pois estamos interessados tanto nos desvios extremos positivos como negativos. Por outro lado, se quisermos escolher ou eliminar apenas os tipos menores, devemos, para sua identificação, aplicar os limites unilaterais inferiores que têm um sinal negativo ; e se quisermos, ao contrário, selecionar os maiores desvios, empregaremos os limites unilaterais superiores, que têm o mesmo valor que os limites unilaterais inferiores, porém com sinal positivo.

Quando estudamos desvios compostos, que seguem as distribuições de Fisher ou de Pearson, temos que resolver um problema bastante diferente. Queremos saber a relação entre a variação conjunta dos desvios reunidos no cálculo do dividendo, e aquêle indicado pelo valor do divisor. Se a variação medida pelo dividendo fôr maior, o valor do desvio composto será maior do que um, e se fôr menor, então o valor do desvio composto será menor do que um.

Quando Fisher publicou as suas primeiras tábuas dos limites que são unilaterais, elas se destinavam apenas para uso na "análise da variança" 
e para êste fim devemos essencialmente aplicar os limites unilaterais. Neste método da análise estatística decompomos o êrro total de acôrdo com as diferentes fontes da variação que podem ser identificadas, sobrando, finalmente, uma componente residual que chamamos o êrro inevitável, inerente ao experimento, ou, simplesmente, o êrro residual. Queremos então saber se a variação entre tratamentos, repetições, etc. medida pelos demais erros calculados no processo da decomposição é maior ou igual do que a variação residual.

A situação, porém, é bem diferente se executarmos um teste de homogeneidade nos mesmos experimentos, pois aqui se pode esperar que a váriação seja em ambas as direções, isto é, que seja possivel tanto que partes do experimento sejam mais homogêneas e assim menos variáveis, como outras mais heterogêneas. Assim, devemos aplicar os limites bilaterais.

Em estudos genéticos e de seleção temos, muito frequentemente, necessidade de aplicar limites bilaterais. Por exemplo, nas famílias de uma geração F3, teremos famílias já razoàvelmente puras e homozigotas, com um êrro "standard" pequeno, e outras ainda segregando fortemente e, consequentemente, com um êrro "standard" bastante grande.

Pelo exposto, é evidente ser necessário decidir nos diferentes testes da análise se devemos aplicar os limites unilaterais ou os limites bilaterais. Anteriormente, esta alternativa era de pouca importância prática, pois apenas existiam tábuas de limites bilaterais para o t-teste, que se baseia nas distribuições de Student, e limites unilaterais para análise dos desvios compostos, que seguem as distribuiçóes de Fisher ou Pearson. As novas tábuas incluídas nesta publicação removem êstes impecilhos práticos.

Queremos ainda explicar mais um ponto que, às vêzes, causa malentendidos. Uma inspeção dos limites que constam das tábuas mostra que os limites bilaterais das distribuições de Student são idênticos aos limites unilaterais de Fisher, com $n 1=1$. A razão é que, matematicamente, estas distribuições de Fisher são iguais à metade das distribuições correspondentes, de Student, como demonstramos matemàticamente em outra publicação (Brieger 4). As ordenadas, que caraterizam o limite de $5 \%$ bilateral de Student, cortam em ambas as extremidades uma área de $2,5 \%$ do resto de $95 \%$ que fica entre as duas ordenadas. A distribuição de Fisher inclui apenas $50 \%$ desta área total, de modo que temos:

$100 \%$ da área de Fisher $=50 \%$ da área de Student

$5 \%$ da área na extremidade de Fisher $=2,5 \%$ da área de Student.

\section{A COMPARAÇÃO DOS DIFERENTES TESTES}

\section{Testes para os desvios relativos simples}

Os testes, baseados nas distribuições de Student, são geralmente chamados t-testes e, quando baseados na distribuição de Gauss, são chamados delta-testes.

Devemos aplicar o delta-teste quando o êrro "standard" que forma o divisor do desvio relativo é calculado, não das variáveis, mas por uma 
fórmula tebrica. Isto se dá, por exemplo, na variação alternativa que segue ou a série binominal ou uma série de Poisson. As fórmulas do êrro "standard" são determinadas nestes casos pelas fórmulas:

\section{Série binominal : $\sigma= \pm \sqrt{\mathrm{p}(1-\mathrm{p}) \mathrm{n}}$ sendo $\mathbf{p}$ a probabilidade do binômio $(\mathrm{p}+(1-\mathrm{p}) \mathrm{n}$}

Série de Poisson : $\sigma= \pm \sqrt{\overline{\mathrm{IM}}}$ sendo $\overline{\mathbf{m}}$ a média da série.

Os limites do delta-teste são os valores extremos e limitantes, aos quais se aproximam os limites do t-teste quando $\mathrm{n} 2$ se torna grande. Geralmente, recomendam-se na literatura, como aproximação suficiente, valores de $n 1$ maiores do que 30. Demonstramos (Brieger, 4) que de fato a distribuição de Student para $\mathrm{n} 2=30$ é intermediária entre aquela para $\mathrm{n} 2=20 \mathrm{e}$ n2 = infinito, sendo a última a distribuição de Gauss. Em geral, a mencionada aproximação é perfeitamente satisfatória, porém inclui nas tábuas dêste trabalho ainda os limites de Student para n2 $=40,50,100$ e 500, tornando-se fácil a interpolação, pelo método exposto acima, para qualquer valor de n2 menor do que 500. (Tábua I e Tábua V).

\section{Testes para os desvios relativos compostos}

Encontramos na literatura três testes : o z-teste original de Fisher, o F-teste de Snedecor (8), e o teta-teste de Brieger $(\mathbf{1 , 2})$. Matemàticamente, trata-se apenas de várias formas da mesma coisa, isto é, como demonstramos em detalhe em outro lugar (4), trata-se dos limites das mesmas distribuições calculadas sòmente com outras unidades de abcissas. As relações matemáticas dos três testes podem ser resumidas pela equação:

\section{Limites do desvio composto $: \mathrm{D}=\mathrm{e}^{\mathrm{z}}$ (Fisher $)=\sqrt{\mathrm{F}}($ Snedecor $)=\vartheta$ (Brieger)}

$\mathrm{O}$ z-teste de Fisher, usado durante muito tempo, foi depois substituído pelo F-teste de Snedecor, que evita o emprêgo desnecessário dos logarítmos naturais, e Fisher adotou recentemente o teste nesta forma [Fisher and Yates, (7)]. O teta-teste, por nós introduzido, simultâneamente, em publicações alemã e portuguêsa (1 e 2), ficou, porém, pouco conhecido, de modo que daremos aqui a justificação principal da sua introdução. Simultâneamente e independente de Snedecor, chegamos à conclusão de que deve ser evitado o emprêgo de logarítmos naturais, com os quais poucos técnicos estão familiarizados, sendo, por isso, necessária a substituição das tábuas originais de Fisher por outras novas. Snedecor escolheu, então, como base o quadrado do desvio relativo composto, quando n6s introduzimos o próprio desvio relativo.

As três formas do teste : z-teste, F-teste e teta-teste são igualmente apropriadas para verificar se obtivemos, num experimento, um valor significante ou não, o que quer dizer, um valor que estivesse dentro ou fora dos limites do acaso. Além disso, os valores de $\mathrm{z}$ e de $\mathrm{F}$ não têm significação alguma, pois são valores abstratos e sem interêsse. $O$ valor de teta, por 
outro lado, nos dá ainda mais uma outra informação: Vamos supor que verificamos, num experimento com adubações diferentes, que o êrro dos tratamentos comparado com o êrro residual deu um valor significante de :

$$
\mathrm{z}=1,27815 \quad \mathrm{~F}=12,8881 \quad \vartheta=3,65
$$

$O$ valor do teta então significa que a variação causada pelos tratamentos é 3,65 vêzes maior do que o êrro residual, o que é uma informação adicional de interêsse imediato.

Citaremos um outro caso : Suponhamos que comparamos 5 tratamentos, num experimento com 4 repetições, e que o êrro residual, baseado em (5-1) vêzes (4-1) ou 12 graus de liberdade era igual a $8 \%$ da média geral do experimento.

Então teremos para as diferenças entre os 5 tratamentos:

Limites unilaterais de teta para $\mathrm{n} 1=5-1=4 ; \mathrm{n} 2=12$ (Tábua IIa);

$$
\begin{aligned}
& \mathrm{P}=1 \%: 3,11 \text { ou } 3,11 \times 8 \%=24,88 \% \text { da média } \\
& \mathrm{P}=1 \%: 2,33 \text { ou } 2,33 \times 8 \%=18,64 \% \text { da média } \\
& \mathrm{P}=5 \%: 1,80 \text { ou } 1,80 \times 8 \%=14,40 \% \text { da média }
\end{aligned}
$$

Sòmente quando os tratamentos aumentam a variabilidade geral para mais do que 18,64 , ou cêrca de $20 \%$ do valor da média geral, podemos tirar conclusões seguras sôbre o seu ef eito usando o $1 \%$ limite de precisão. Cálculos desta natureza podem ser de importância nos estudos preliminares antes da instalação de um experimento definitivo. Não é possível fazer tais previsões usando os valores de $z$ ou de $F$.

A informação adicional contida nos valores de teta são ainda de importância em muitos estudos sôbre a hereditariedade de caracteres quantitativos, e em experimentos de seleção.

Nos primeiros queremos saber não sòmente se a variação em F2 é superior à de F1, em consequência da segregação mendeliana, mas, ainda, quanto maior ela será, e que êste "quanto maior" nos permita tirar conclusões sôbre o número e o efeito dos gens envolvidos. Na análise das famílias das gerações posteriores queremos e devemos saber não apenas quais as famílias estatìsticamente mais homogêneas e menos heterogêneas, mas, ainda, quanto mais homogêneas ou heterogêneas elas são. A primeira informação, aquela sôbre a significância ou insignificância, pode ser obtida usando qualquer dos limites na forma do $\mathrm{z}, \mathrm{F}$ ou teta-teste, porém a segunda informação é apenas contida nos valores do teta.

$\mathrm{Na}$ fase inicial dos experimentos de seleção é sempre de valor saber quanto mais variáveis são diferentes famílias, para avaliar quais as mais promissoras para a seleção. $\mathrm{Na}$ fase final do trabalho queremos saber. se já chegamos a uma redução da variabilidade e homogeneidade razoável.

Do ponto de vista pedagógico, o teta-teste tem o seu grande valor, pois, tanto o estudante como o técnico, sem preparo matemático, compre- 
enderão fàcilmente a sua significação, mesmo não estando familiarizado com os valores de segunda potência do F-teste e ainda muito menos com os logarítmos naturais do z-teste. $O$ emprêgo dos limites em têrmos de teta tornam tôdas as discussões e comparações mais fáceis, pois todos os valores em discussão são da mesma ordem : variáveis, erros "standard" e limites de significância.

Finalmente, não vemos qualquer necessidade matemática para usar na análise dos desvios compostos um outro sistema de abcissas do que no estudo dos desvios simples. Será muito fácil calcular os limites de F, por exemplo, para a distribuição de Gauss, usando como unidade da abcissa a variância, isto é, o quadrado do êrro "standard" e fazendo a integração nesta base. Uma vez que ninguem faz isto na distribuição "normal" ou de Gauss, não vemos razão alguma para que seja feito nas distribuições de Fisher e Pearson.

Parece-nos muito mais vantajoso, especialmente para aquêles que apenas querem aplicar os métodos da estatística, poder trabalhar com poucos têrmos, todos da mesma dimensão : as variáveis, as médias como valores representativos da série destas variáveis, e o êrro "standard", como medida direta da sua variação, evitando o valor abstrato da variância que é da segunda dimensão, empregada no F-teste, e evitando também o valor teórico dos logarítmos naturais, necessários no z-teste.

\section{Relação entre o $\chi^{2}$-teste e ota-teste}

Existe, como explicamos em outro trabalho (4), uma relação muito simples entre o valor de $\chi^{2}$ e o desvio relativo, sendo :

$$
\begin{aligned}
& \chi^{2}=\mathrm{D}^{2} \cdot \mathrm{n}\left(\chi^{2}\right) \text { ou } \\
& \mathrm{D}=\sqrt{\frac{\chi^{2}}{\mathrm{n}\left(\chi^{2}\right)}} \text { quando } \frac{\mathrm{n} 1=\mathrm{n}\left(\chi^{2}\right)=\text { qualquer valor }}{\mathrm{n} 2=\text { infinito }}
\end{aligned}
$$

Para facilitar a comprovação desta fórmula importante, incluímos na tábua $\mathrm{X}$ os valores de $\chi^{2}$, em forma abreviada segundo Fisher and Yates (7), e os valores de teta das novas tábuas para limites unilaterais.

A fórmula dada acima pode ser aplicada em dois tipos de problemas.

Em primeiro lugar discutiremos a transformação de valores de teta em $\chi^{2}$. Em testes de homogeneidade comparamos frequentemente erros "standard" individuais com um só êrro geral, baseado em grau de liberdade tão grande que podemos considerá-lo pràticamente como infinitamente grande. Neste caso, podemos combinar todos os valores de teta dos erros individuais num $\chi^{2}$ total e determinar, pela significância ou insignificância dêste, se o conjunto de amostras era homogêneo ou não. Chamando os diferentes desvios $\mathrm{Da}, \mathrm{Db} . .$, , os erros individuais $\sigma \mathrm{a}, \sigma \mathrm{b} . \ldots$, e os seus graus de liberdade na, nb..., temos :

$$
\begin{aligned}
& \mathrm{Da}=\frac{\sigma a}{\mathrm{na}} ; \frac{\mathrm{n} 1=\mathrm{na}}{\mathrm{n} 2=\mathrm{inf} .} ; \mathrm{Db}=\frac{\sigma b}{\mathrm{nb}} ; \frac{\mathrm{n} 1=\mathrm{nb}}{\mathrm{n} 2=\mathrm{inf} .} \\
& \chi^{2}(\text { total })=\Sigma\left(\mathrm{na} \mathrm{Da}^{2}+\mathrm{nb} \mathrm{Db}^{2} \ldots\right)=\Sigma\left(\mathrm{n} 1 D^{2}\right) ; \\
& \mathrm{n}\left(\chi^{2}\right)=\mathrm{na}+\mathrm{nb} \ldots
\end{aligned}
$$


A segunda aplicação da transformação é muito útil, quando temos que analisar valores de $\chi^{2}$ baseados em um grau de liberdade maior do que 30. Nestes casos, as tábuas de limites não mais podem ser usadas e se recomenda em geral a aplicação de uma fórmula baseada no fato de que as distribuiçoes de Pearson, para grau de liberdade grande, se aproximam a uma distribuição, aproximada, de Gauss com média 1 e o êrro "standard" igual a $1: \sqrt{2 \mathrm{n} 1}$. Podemos usar assim a fórmula (Brieger 4, pg. 352) :

$$
\mathrm{D}=\sqrt{\frac{\chi^{2}}{\mathrm{n}\left(\chi^{2}\right)}}=1 \pm \frac{\text { limite de Gauss }}{\sqrt{2 \mathrm{n}\left(\chi^{2}\right)}} \frac{\mathrm{n} 1=\mathrm{n}\left(\chi^{2}\right)}{\mathrm{n} 2=\mathrm{inf} .}
$$

Esta fórmula contém uma aproximação que podemos agora evitar uma vez que as novas tábuas trazem os limites do desvio relativo composto por muitas combinações de valores de $n 1$ maiores do que 30 e valores de n2 iguais a inf nito. Assim, podemos dividir o valor de $\chi^{2}$ achado pelo seu grau de liberdade e extrair a raiz para ver se êle é maior ou não do que os limites unilaterais das tábuas de teta para $n 1=n\left(\chi^{2}\right) ; n 2=$ infinito.

Para dar um exemplo, comparamos os valores dos limites de $\chi^{2}$, calculados com a antiga e a nova fórmula, para o $5 \%$ limite unilateral e para $\mathrm{n}\left(\chi^{2}\right)=100$ :

$$
\mathrm{D}=\sqrt{\frac{\chi^{2}}{\mathrm{n}\left(\chi^{2}\right)}}=1 \pm \frac{1,6449}{\sqrt{200}}=1,12
$$

Achamos para o 5\% limite unilateral do desvio relativo na tábua IId o valor de :

$$
1,11 \frac{\mathrm{n} 1=100}{\mathrm{n} 2=\mathrm{inf} .}
$$

Os dois valores, 1,12 e 1,11 , sẫo pràticamente idênticos.

\section{EXEMPLOS DA APLICAÇÃO DAS NOVAS TẢBUAS}

\section{Material usado}

O material que pretendemos usar como exemplos é tirado de três experimentos diferentes.

Ficus elastica, comprimento das fôlhas. Usamos nas nossas aulas práticas, já há nove anos, fôlhas dessa figueira como material pedagógico, pelo qual os alunos poderão aprender todos os cálculos e testes da análise estatística.

A fim de familiarizar os alunos com os conceitos de "amostras" e de "população", as fôlhas colhidas são divididas em grupos de 21 para cada amostra, sem aplicação de qualquer escolha ou seleção.

Uma vez que a variação do tamanho destas fôlhas terá sido causada pela ação de fatôres acidentais, as amostras de 21 fôlhas deviam corressponder às distribuições do acaso. Escolhemos como exemplo os dados colhidos em 1945 por 35 grupos de alunos. 
Milho Precoce Brasileiro, altura das plantas (Brieger, ainda não publicado). Trata-se de uma experiência muito extensa sôbre a hereditariedade de caracteres quantitativos, de interêsse também do ponto de vista da genética aplicada. Usaremos nesta publicação os dados referentes a 63 famílias da terceira geração do cruzamento inicial entre milhos precoces estrangeiros, não adaptados ao nosso clima, e o milho tardio brasileiro. A variação não pode ser muito homogênea, pois, além da variação de acaso, devemos esperar a dos efeitos da segregação mendeliana.

Frutas Cítricas, reląções entre cavalo e enxêrto (Brieger e Moreira, 5). Os dados completos já foram publicados de modo que uma explicação se torna desnecessária.

\section{Testes baseados nas distribuições de Student}

Ficus elastica - As 35 médias parciais constam do quadro I e variam em volta da média geral de $176,15 \mathrm{~mm}$ desde $191,00 \mathrm{~mm}$ até $164,66 \mathrm{~mm}$. O êrro "standard" da distribuição era igual a $\pm 25,94 \mathrm{~mm}$ sendo calculado de $(21 \times 35)-1=734$ graus de liberdade.

Executamos então um teste para resolver se havia entre as 35 amostras de 21 fôlhas algumas com média estatisticamente maior ou menor do que a média geral. Comparando um conjunto de 35 amostras, devemos aplicar os seguintes limites de probabilidade.

$P=\frac{1}{5 . \mathrm{N}}=\frac{1}{175} ;$ limite convencional de $\mathrm{P}=1 \%$

$P=\frac{1}{10 . N}=\frac{1}{350} ;$ limite convencional de $P=1 \%$

Os desvios relativos deverão ser calculados pela fórmula :

$$
\mathrm{t}=\frac{\mathrm{v}-\overline{\mathrm{v}}}{\overline{\mathrm{v}}} \text { sendo } \frac{\mathrm{n} 1=1}{\mathrm{n} 2=734}
$$

Uma vez que a variação pode ser nas duas direções, para valores positivos ou negativos de $t$, devemos usar limites bilaterais.

Os valores dos limites do desvio encontramos na tábua dos limites da distribuição de Student, empregando como aproximação satisfatória os valores para $\mathrm{n} 1=1 ; \mathrm{n} 2=500$. (Tábua 1).

Limites de probabilidade $(1 \%) \mathrm{t}=2,60$

Limites de improbabilidade $(1 \%$ ) $t=3,33$

Comparando agora os 35 valores analisados da quinta coluna do quadro I com êstes limites, podemos constatar que não aparece nenhum valor de t maior do que o um por mil limite e apenas um valor na região de dúvida entre $1 \%$ e $1 \%$ limite. Evidentemente, tôdas as 35 amostras são apenas algèbricamente, mas não estatìsticamente, diferentès entre si. 
Além dêste teste das extremidades, foi também executado um teste da distribuição inteira. As médias foram reunidas em classes de $10 \mathrm{~mm}$ e as frequências observadas comparadas pelo $\chi^{2}$ teste com as frequências esperadas. Uma vez que o êrro "standard" foi calculado de um grau de liberdade muito elevado, podemos usar as frequências esperadas da distribuição de Gauss (Brieger, 4). Nenhum valor individual de $\chi^{2}$, nem o $\chi^{2}$ total igual a 0,80 , são significantes.

Frutas Cátricas - O quadro III dá as médias parciais do diâmetro do tronco das árvores a $20 \mathrm{~cm}$ (cavalo) e $40 \mathrm{~cm}$ (enxêrto), distância do solo. O teste da decomposição do êrro, executado anteriormente (5), demonstrou que a variação entre as 12 combinações cavalo-enxêrto é muito significante, sendo o êrro "entre" cêrca de 10 vêzes maior do que o êrro residual. Assim, um teste em relação à média geral desta série heterogênea de médias parciais parece pouco interessante. Notando-se, porém, que as médias parciais não formavam uma série contínua, resolveu-se executar um teste para as diferenças entre as médias consecutivas, organizando-se, para êste fim, as médias em ordem decrescente.

Tratando-se de uma análise em conjunto de séries de 11 diferenças consecutivas escolhidas entre um total de 66 diferenças que podiam ser calculadas entre as 12 médias de cada série, podemos determinar os limites de probabilidade pela formula:

$$
\begin{aligned}
& \mathrm{P}=\frac{1}{5 \mathrm{~N}}=\frac{1}{330} ; \text { limite } \begin{array}{c}
\text { convencional } \mathrm{P}=1 \% \\
(\text { Tábua XI) }
\end{array} \\
& \mathrm{P}=\frac{1}{10 \mathrm{~N}}=\frac{1}{660} ; \text { limite } \begin{array}{c}
\text { convencional } \mathrm{P}=1 \% \\
(\text { Tábua XI) }
\end{array}
\end{aligned}
$$

Para o cálculo dos desvios empregamos o êrro residual do experimento, baseado em cêrca de 250 graus de liberdade :

$$
\mathrm{D}=\frac{\overline{\mathrm{v}} 1-\overline{\mathrm{v}} 2}{\sigma \text { dif. }} \times \frac{\mathrm{n} 1=1}{\mathrm{n} 2=2 \times 250=500}
$$

Uma vez que calculamos as diferenças consecutivas numa série organizada em ordem decrescente, tôdas as diferenças têm que ser positivas, sendo excluídos os valores negativos de desvios relativos. Assim, devemos usar os limites unilaterais superiores de $t$ para a distribuição de Student com $\mathrm{n} 1=1 ; \mathrm{n} 2=2 \times 250=500$, os quais são

$$
\begin{array}{ll}
\text { Limite de probabilidade }(1 \%) & t=2,34 \\
\text { Limite de improbabilidade }(1 \%) & t=3,12
\end{array}
$$

Encontramos fora do limite de improbabilidade de $1 \%:-7$ valores na região de dúvida : dentro do limite de probabilidade de $1 \%$ : 
Existem, no mínimo, 7 interrupçz̃es nas duas séries das médias parciais separando combinações de cavalo-enxêrto com troncos significantemente mais grossos, de outras com troncos mais finos.

Um teste da distribuição inteira não podia ser executado para as diferenças consecutivas. Se tivéssemos esta intenção deveríamos calcular tôdas as diferenças possíveis e não nos limitar a estudar as diferenças, consecutivas, escolhidas de tal modo que elas sempre são os valores menores e positivos que podem ser encontrados.

Milho Precoce Brasileiro : - As médias parciais da altura média das plantas nas 63 famílias constam do quadro $V$. O teste entre-dentro já revelou a grande heterogeneidade existente, a qual é uma consequência da segregação mendeliana para numerosos fatôres hereditários. $\mathrm{O}$ t-teste relativo à média geral de $96,26 \mathrm{~cm}$ mostra que um número muito grande das médias parciais está fora dos limites de significância. As diferenças consecutivas, por outro lado, são tôdas pequenas e insignificantes, não dando sinal da interrupção na série contínua das médias.

A execução do teste em relação à média geral torna-se difícil de ser explicada no caso em aprêço, pela grande diferença na dimensão das médias parciais. Uma vez que o êrro "standard" é matemàticamente dependente da dimensão da média, a determinação dos erros das diferenças se torna bastante difícil (Brieger, 3). Mais tarde voltaremos ainda a êste ponto.

\section{Testes baseados nas distribuições de Fisher}

Ficus elastica - Os erros da distribuição para as 21 fôlhas de cada amostra constam do quadro II, segunda coluna, e na terceira coluna são dados os 35 desvios relativos compostos, obtidos pela divisão dos erros individuais pelo êrro total de $\pm 25,24$.

Como anteriormente, calculamos em primeiro lugar os limites da região de dúvida :

$$
\begin{aligned}
& P=\frac{1}{5 \mathrm{~N}}=\frac{1}{175} ; \text { limite convencional } \mathrm{P}=1 \% \\
& \mathrm{P}=\frac{1}{10 \mathrm{~N}}=\frac{1}{350} ; \text { limite convencional } \mathrm{P}=1 \%
\end{aligned}
$$

Os quocientes teta têm os seguintes graus de liberdade :

$$
\mathrm{D}=\frac{\text { individual }}{\text { total }} \quad \frac{\mathrm{n} 1=20}{\mathrm{n} 2=734}
$$

Evidentemente, poderíamos esperar que algumas amostras fôssem mais e outras menos variáveis, de modo que devemos aplicar os limites bilaterais, os quais são mais próximos da tábua da distribuição de Fisher (Tábua III) $\operatorname{com} \mathrm{n} 1=20 ; \mathrm{n} 2=500$.

$$
\begin{array}{ll}
1 \% \text { limite } & : 0,60-1,45 \\
1 \% \text { limite } & : 0,51-1,58
\end{array}
$$


O quadro II mostra que nenhum dos 35 valores está fora dêstes limites, e os valores mais extremos observados, maiores ou menores, estão perto dos limites de 5\% probabilidade. Assim, é evidente que a variabilidade das amostras é bastante homogênea.

Para completar a análise da homogeneidade foi ainda executado um teste da distribuição inteira. Para êste fim, os valores $D$ foram reunidos em classes de um décimo e estas comparadas com as frequências esperadas de uma distribuição de Pearson com $\mathrm{n} 1=20 ; \mathrm{n} 2=$ infinito, (Tábua IX) que podem ser usados como uma boa aproximação (4). Os dados constam do quadro II e tanto os valores individuais como o valor total de $\chi^{2}$ provam a completa conformidade das distribuições, observada e esperada. Os resultados estão ainda representados na fig. 6.

Está assim comprovado que a variabilidade das fôlhas nestas amostras dependia ùnicamente de fatôres acidentais.

Frutas cítricas - Nesta experiência foi executada uma análise detalhada das possíveis fontes sistemáticas da variação em seis caracteres diferentes dos três enxertos : Baianinha, Pêra e Pomelo. Do êrro total foram separadas quatro componentes : entre 2 quadras ou "super blocks", nas quais, cada vez, metade dos cavalos era reunida $(\mathrm{nf}=1)$; entre os cavalos com $\mathrm{nf}=10$; entre repetiçбes $(\mathrm{nf}=6) \mathrm{e}$, finalmente, a interação entre cavalos e repetições com $\mathrm{nf}=30$. Ficou, então, finalmente, um êrro residual com cêrca de $\mathbf{2 5 0}$ graus de liberdade, correspondente à variação individual das árvores individuais. O quadro IV não apresenta os valores dos erros mesmos, mas dá os desvios relativos compostos, obtidos pela divisão dos erros "entre" e o êrro residual.

Para cada uma destas comparações temos, então, $6 \times 3=18$ valores. que devem ser considerados como um conjunto, e os limites de probabilidade e improbabilidade serão assim :

$$
\begin{aligned}
& P=\frac{1}{5 \mathrm{~N}}=\frac{1}{90} ; \text { limite convencional } \mathrm{P}=1 \% \\
& \mathrm{P}=\frac{1}{10 \mathrm{~N}}=\frac{1}{180} ; \text { limite convencional } \mathrm{P}=1 \%
\end{aligned}
$$

Não pode haver dúvida de que devemos usar os limites das respectivas distribuições de Fisher, isto é, aplicar o teta-teste, mas é preciso ainda resolver se serão empregados os limites bilaterais ou unilaterais. De acôrdo com a teoria fundamental de decomposição do êrro, podemos apenas esperar que as fontes especiais da variação aumentariam talvez a variação, mas parece impossível que algumas delas pudessem reduzir a variação residual. Assim. deveríamos aplicar apenas os limites unilaterais e superiores. As 
tábuas não dão os limites para $\mathrm{n} 2=250$, de modo que devemos calcular os limites de acôrdo com o processo de interpolação já descrito (Tábua VI) obtendo os valores

\begin{tabular}{|c|c|c|c|c|}
\hline $\mathrm{n} 2=250$ & $\mathrm{n} 1=1$ & $\mathrm{n} 1=6$ & $\mathrm{n} 1=10$ & $\mathrm{n} 1=30$ \\
\hline $\begin{array}{l}1 \% \\
1 \%\end{array}$ & $\begin{array}{l}3,36 \\
2,62\end{array}$ & $\begin{array}{l}1,99 \\
1,71\end{array}$ & $\begin{array}{l}1,78 \\
1,56\end{array}$ & $\begin{array}{l}1,50 \\
1,37\end{array}$ \\
\hline
\end{tabular}

A variação entre quadras bem como a variação entre cavalos são significantemente maiores do que o êrro residual, sendo todos os valores dos desvios maiores do que o $1 \%$ limite. Notamos ainda o seguinte : a variabilidade entre quadras é de 10 a 20 vêzes maior e aquela dos cavalos dentro das quadras, apenas de 8 a 10 vêzes maior do que o êrro residual.

A variação do terreno é também considerável : dos 18 valores de desvios relativos compostos temos :

fora do $1 \%$ limite .................... 11

entre $1 \%$ e $1 \%$ limite (região de dúvida)....... 4

Insignificantes $\ldots \ldots \ldots \ldots \ldots \ldots \ldots \ldots \ldots, 3$

Assim, três valores são insignificantes e 4 apenas duvidosos, sendo os 11 restantes significantemente maiores do que o êrro residual. $O$ aumento da variabilidade, causada pela heterogeneidade do terreno, é de uma ordem bem menor do que o aumento causado pelos diferentes cavalos : os efeitos do terreno apenas dobram a variabilidade.

A interação cavalo-repetição que indica se os cavalos respondem ou não igualmente à heterogeneidade do terreno mostra o seguinte :

significante (fora do $1 \%$ limite) ........... 0

duvidoso (entre $1 \%$ e $1 \%$ limite) $\ldots \ldots \ldots \ldots \ldots 2$

insignificante $\ldots \ldots \ldots \ldots \ldots \ldots \ldots \ldots \ldots \ldots, 16$

18

Temos, assim, apenas 2 valores duvidosos contra 16 insignificantes. Mas, mesmo assim, devemos registar de modo geral um pequeno aumento de variabilidade, pois nenhum dos valores dá indicação de uma redução acidental da variação, sendo todos os erros da interação maiores do que o êrro residual. A interação aumenta a variabilidade, mas apenas cêrca de 12 vêzes, como indicado pelo valor de teta.

Milho Precoce Brasileiro - Devemos comparar os erros "standard" das 63 familias para verificar se entre elas existem algumas com maior heterogeneidade em consequência do seu maior grau de heterozigotia, ou 
com maior homogeneidade, sendo mais homozigotas. A análise apresenta mais uma complicação. As médias são de tal maneira diferentes, que a simples comparação dos erros "standard" não parece mais permissivivel. Como explicamos (3), deve ser usada uma compensação aritmética para as variações da dimensão das médias, aplicando o que chamamos índice da variância, isto é, a raiz quadrada do quociente entre variância e média, ou, então, o quociente entre êrro "standard" e a raiz quadrada da média o que, matemàticamente, é a mesma coisa. Demonstramos em numerosos exemplos que esta transformação das dimensões elimina satisfatòriamente os efeitos da dimensão diversa das variáveis e da sua média sôbre o valor do êrro "standard" (3).

$\mathrm{Na}$ análise estatística, porém, surge a primeira vista uma outra dificuldade. Qual será a distribuição de acaso que êste índice seguirá? $O$ seu dividendo segue uma distribuição de Fisher e o seu divisor uma de Student ou de Gauss, e, além disso, ambos, dividendo e divisor, variam coordenadamente. Mas, sem prejudicar muito a eficiência dos testes e como também em vários outros casos (Brieger, 4) podemos considerar a média como constante, e, neste caso, o índice seguirá a mesma distribuição de acaso que o êrro "standard", do qual foi derivado por divisão.

Para melhor ilustrar estas considerações, executaremos os testes, tanto com os próprios valores dos erros "standard" como, também, com os valores dos índices da variância, constando ambos das respectivas colunas do quadro V. Na primeira comparação usamos o êrro dentro, comum a tôdas as famílias, calculado pela fórmula:

$\sigma \mathrm{D}= \pm \sqrt{\frac{\Sigma \sigma_{2} .(\mathrm{np})}{\Sigma(\mathrm{np})}} \begin{aligned} & \text { sendo } \mathrm{np} \text { o grau de liberdade de cada um } \\ & \text { dos erros individuais. }\end{aligned}$ $\begin{array}{cl}\mathrm{i}(\sigma \mathrm{D})=\frac{\sigma \mathrm{D}}{\sqrt{\overline{\overline{\mathrm{v}}}}} & \text { sendo } \overline{\overline{\mathrm{v}}} \text { a média geral de tôdas as amostras : } \\ & \overline{\overline{\mathrm{v}}}=\frac{\Sigma \mathrm{v}}{\Sigma \mathrm{Np}}, \text { sendo }\end{array}$

Np o número total de variáveis em cada amostra.

Os limites de probabilidade para esta comparação de um conjunto de 63 desvios relativos já foram determinados acima:

$$
\begin{aligned}
& P=\frac{1}{4 N}=\frac{1}{252} ; \text { limite convencional } P=1 \% \\
& P=\frac{1}{10 N}=\frac{1}{630} ; \text { limite convencional } P=1 \% .
\end{aligned}
$$

Devemos aplicar os limites bilaterais dos desvios relativos, de vez que tanto podia haver familias mais homogêneas como mais heterogêneas. Sendo ainda os valores $\mathrm{Np}$ diferentes, temos que calcular os limites para as distribuições de Fisher de $n 1=28$ ate $n 1=36$ e de $n 2=$ infinito, que é uma aproximação indicada pelo valor real de $\mathrm{n} 2=\mathbf{2 . 0 3 2}$. 


\section{LIMITES BILATERAIS}

LIMITES SUPERIORES PARA n1 =

\begin{tabular}{c|c|c|c|c|c|c|c|c|c}
\hline $\mathrm{P}$ & 28 & 29 & 30 & 31 & 32 & 33 & 34 & 35 & 36 \\
\hline $1 \%$ & 1,37 & 1,36 & 1,36 & 1,35 & 1,35 & 1,34 & 1,34 & 1,34 & 1,33 \\
$1 \%$ & 1,44 & 1,43 & 1,43 & 1,42 & 1,41 & 1,41 & 1,40 & 1,40 & 1,39 \\
\hline
\end{tabular}

LIMITES INFERIORES PARA $\mathrm{n} 1=$

\begin{tabular}{|c|c|c|c|c|c|c|c|c|c|}
\hline $\mathbf{P}$ & 28 & $29^{\circ}$ & 30 & 31 & 32 & 33 & 34 & 35 & 36 \\
\hline $\begin{array}{l}1 \% \\
1 \%\end{array}$ & $\begin{array}{l}0,66 \\
0,57\end{array}$ & $\begin{array}{l}0,67 \\
0,58\end{array}$ & $\begin{array}{l}0,67 \\
0,58\end{array}$ & $\begin{array}{l}0,68 \\
0,59\end{array}$ & $\begin{array}{l}0,68 \\
0,59\end{array}$ & $\begin{array}{l}\mathbf{0 , 6 9} \\
\mathbf{0 , 6 0}\end{array}$ & $\begin{array}{l}0,69 \\
0,60\end{array}$ & $\begin{array}{l}0,69 \\
0,61\end{array}$ & $\begin{array}{l}0,70 \\
0,62\end{array}$ \\
\hline
\end{tabular}

O resultado é o seguinte :

\begin{tabular}{|c|c|c|c|c|c|}
\hline \multirow{2}{*}{ Referente ao: } & \multicolumn{2}{|c|}{ LIMITES INFERIORES } & \multirow{2}{*}{$\begin{array}{l}\text { Insi- } \\
\text { gnifi- } \\
\text { cante }\end{array}$} & \multicolumn{2}{|c|}{ LIMITES SUPERIORES } \\
\hline & $\begin{array}{l}\text { Significante } \\
\text { Fora } 1 \%\end{array}$ & $\begin{array}{c}\text { Duvidoso } \\
\text { Entre } \\
1 \% \text { e } 1 \%\end{array}$ & & $\begin{array}{c}\text { Duvidoso } \\
\text { Entre } \\
1 \% \text { e } 1 \%\end{array}$ & $\begin{array}{l}\text { Significante } \\
\text { Fora } 1 \%\end{array}$ \\
\hline $\begin{array}{l}\text { Êrro "standard" } \\
\text { Indice de Variância }\end{array}$ & $\begin{array}{l}1 \\
1\end{array}$ & $\begin{array}{l}2 \\
-2\end{array}$ & $\begin{array}{l}54 \\
58\end{array}$ & $\underline{3}$ & $\begin{array}{l}3 \\
2\end{array}$ \\
\hline
\end{tabular}

Usando os índices, eliminamos uma parte de heterogeneidade, aquela que era devida às alterações de dimensão das médias. Mas, mesmo assim, ficou uma família que, certamente, e outras duas, que, possivelmente, eram menos variáveis e assim mais homozigotas, e duas outras famílias que eram mais heterogêneas do que as restantes.

A vantagem do emprêgo do índice fica, porém, muito mais em evidência quando executamos um teste da distribuição inteira. Na escolha da distribuição esperada, as diferenças nos graus de liberdade que variam de 27 at6 35 para as diferentes famílias são sem importância, pois êles afetam apenas as extremidades, quando de outro lado a forma geral da curva é pouco influenciada. Podemos usar como uma boa aproximação as frequências de uma distribuição de Pearson com $n 1=30 ; n 2=$ infinito (Tábua IX).

A comparação foi feita pelo $\chi^{2}$-teste, tanto para os erros "standard" como para os índices de variância (Quadro VI). No primeiro caso, os valores de $\chi^{2}$ são altamente significantes, indicando a existência de uma variação anormal e não de acaso. A concordância das frequências observadas $\mathbf{e}$ 
esperadas na análise dos índices é de outro lado muito evidente. Os números excessivos nas extremidades, cuja existência verificamos antes, tornam-se sem efeito no $\chi^{2}$-teste, pois é necessário reunir diversas classes até que a frequência esperada acumulada se torne maior do que 5 , condição básica para a execução do $\chi^{2}$-teste.

Os gráficos na fig. 5 dâo ainda uma impressão mais nítida dos resultados obtidos. O histograma dos desvios relativos dos erros "standard", está completamente em desacôrdo com a curva de Pearson e o histograma referente aos índices das variâncias só desvia da curva de Pearson nas extremidades. Assim, o uso do índice da variância está plenamente justificado.

Do ponto de vista da genética, mais duas comparações são de interêsse. A variabilidade das famílias da terceira geração deveria ser, de um modo geral, maior do que a variação em F1 e menor do que em F2. Assim, devem ser feitas mais duas comparações pelo teta-teste, usando evidentemente os limites unilaterais ; no primeiro caso, os limites superiores e, no segundo, os limites inferiores.

Aplicando as tábuas de interpolação obtivenos os seguintes valores :

\section{LIMITES UNILATERAIS}

\begin{tabular}{l|l|l|l|l|l|l|l|l|l|l}
\hline $\mathbf{8}$ & \multicolumn{8}{c}{ GRAUS DE LIBERDADE $\mathrm{n} 1$} \\
$\mathrm{P}$ & 28 & 29 & 30 & 31 & 32 & 33 & 34 & 35 & 36 \\
\hline
\end{tabular}

LIMITES INFERIORES

\begin{tabular}{l|l|l|l|l|l|l|l|l|l}
$1 \%$ & 0,69 & 0,69 & 0,69 & 0,70 & 0,71 & 0,71 & 0,71 & 0,71 & 0,72 \\
$1 \%$ & 0,59 & 0,60 & 0,60 & 0,61 & 0,62 & 0,63 & 0,64 & $\mathbf{0 , 6 4}$ & $\mathbf{0 , 6 5}$ \\
\hline
\end{tabular}

LIMITES SUPERIORES

\begin{tabular}{l|l|l|l|l|l|l|l|l|l}
$1 \%$ & 1,36 & 1,35 & 1,35 & 1,34 & 1,33 & 1,33 & 1,32 & 1,32 & 1,32 \\
$1 \%$ & 1,50 & 1,49 & 1,47 & 1,40 & 1,45 & 1,45 & 1,44 & 1,44 & 1,43 \\
\hline
\end{tabular}

A comparação dos desvios relativos com os limites acima indicados dão o seguinte resultado (Quadro VI) :

Comparação com F1 (índice dà variância 1,60): Aparece um desvio fora de $1 \%$ limite superior e cinco estão na região da dúvida superior entre os limites de probabilidade $1 \%$ e $1 \% ; 1$ desvio na região de dúvida inferior. $\mathrm{E}$ interessante notar-se que uma das famílias tem apenas metade $(0,58)$ da variabilidade de $\mathrm{F} 1$, como indicado pelo valor de teta.

Comparação com F2 (indice da variância 2,20): 3 desvios fora do $1 \%$ limite inferior e 5 na região de dúvida inferior; um desvio fora do $1 \%$ limite superior. As famílias mais variáveis dão no teta-teste um desvio relativo de 1,51 , sendo assim uma vez e meia mais variável do que famílias em F2. 
$\mathrm{O}$ aparecimento de familias menos variáveis do que $\mathrm{F} 1$ e mais variáveis do que F2 não era esperado do ponto de vista da genética. Devem ser realizados novos experimentos para esclarecer o caso e para determinar em definitivo se a variabilidade inesperada é realmente genotípica, ou fenotípica.

Mais uma vez verificamos que a maioria dos desvios relativos não são significantemente diferentes dos valores usados na comparação baseada nos índices da variância de F1 e F2. A comparação da distribuição inteira esclarece a situação de um modo mais geral (Quadro VI). Os valores de $\chi^{2}$ são altamente significantes em ambos os casos e mostram a tendência geral de os índices da variância de F3 serem maiores do que os índices de F1 e menores do que em F2.

$O$ teta-teste nos indica ainda que, na média, a variação da terceira geração é $1,90: 1,60=1,20$ vêzes maior do que em $\mathrm{F} 1$ e apenas 1,90 : $2,20=0,86$ vêzes aquela em F2.

\section{RESUMO}

1. O principal fim dêste trabalho consiste em apresentar uma série de novas tábuas a serem aplicadas nos teta-testes como nos t-testes. As tábuas publicadas até agora (Fisher (7), Fisher and Yates (7), Snedecor (8), Brieger (1), (2) tinham, a nosso ver, três defeitos : a) Elas não podiam ser aplicadas em numerosos casos por falta dos valores referentes a muitas combinaçס̃es de graus de liberdade; b) Existiam apenas tábuas para os limites bilaterais de $t$ e para os limites superiores unilaterais do teta ; c) Em terceiro lugar, faltavam tábuas auxiliares que permitissem uma interpolação com boa aproximação.

As novas tábuas apresentadas contêm os limites na mesma dimensão do desvio relativo, sendo calculadas com a ajuda de fórmulas para as distribuiçzes de acaso (Brieger, 4), nas quais a frequência dos desvios é usada como ordenada e o próprio desvio relativo como unidade da abcissa.

2. Definimos os desvios relativos como os quocientes entre desvios e o seu êrro "standard". Quando consta no dividendo apenas um desvio, designamos o quociente : o desvio relativo simples. Se de outro lado analisarmos em conjunto váriós desvios, devemos usar como dividendo a sua estimativa média e balançada, isto é, a raiz quadrada da soma dos desvios quadrados dividida pelo grau de liberdade correspondente. Dividindo esta estimativa pelo êrro "standard" apropriado, obtivemos o desvio relativo composto. O desvio composto é assim um quociente entre dois erros "standard", dévendo ser usado como divisor o êrro "standard" que com mais justificação será considerado a melhor aproximação ao valor ideal do êrro.

3. A variação dos desvios simples, quando o valor do grau de liberdade do divisor n2 fôr igual a finito, segue as distribuiçóes de. Studenit e quando esta fôr infinito a distribuição de Gauss, também chamada "normal". Consequentemente, aplicaremos, na análise estatística, o t-teste no primeiro e o delta-teste no segundo caso. 
A variação dos desvios compostos, por outro lado, segue uma das distribuições de Fisher, quando o valor de $n 2$ fôr finito, e uma das distribuições de Pearson, quando o $\mathrm{n} 2$ fôr infinito. Na análise estatística aplicase então o teta-teste.

4. Explicamos as principais vantagens da aplicação do teta-teste, introduzido por Brieger em 1937 (1, 2), sôbre o z-teste de Fisher (7) e o F-teste de Snedecor (8). Matemàticamente, a diferença consiste no fato de que, na integração das equaçōes das distribuições de acaso e no cálculo dos limites, são usadas diferentes bases : o logarítmo natural dos limites relativos (Fisher), e seu quadrado (Snedecor), e o próprio desvio relativo (Brieger). Tôdas as três formas do teste servem igualmente, usando-se as tábuas correspondentes, para determinar os limites de significância. Mas o teta-teste traz, além disso, as seguintes vantagens : a) o valor de teta indica quantas vêzes menor ou maior é a variação encontrada ; b) a execução dos testes é mais homogênea, pois todos os valores : delta, t e teta são da mesma dimensão, e as curvas das distribuições podem ser diretamente comparadas (compare Brieger, 4); c) tanto os estudantes como os técnicos não especializados compreenderão bem melhor o que estão fazendo se executarem testes da mesma dimensão.

5. Executando qualquer um dos testes citados, é necessário determinar, em primeiro lugar, os limites de probabilidade ou de precisão que terão que ser aplicados. Em vista da dificuldade de se fixarem êstes limites objetivamente, recomendamos (Brieger, 1, 2) a indicação de dois limites : o limite de probabilidade e de improbabilidade, ficando entre estas o que chamamos a região de dúvida. Os dados das tábuas e uma fórmula apresentada no texto ajudam a determinar quais os limites indicados, em função do número de desvios relativos a serem tomados em consideração conjunta.

6. Em seguida, deve ser decidido se a natureza do caso em estudo obriga o emprêgo de limites unilaterais ou bilaterais.

7. As tábuas I a $\mathrm{V}$. dão os limites de $\mathbf{t}$ e de teta para um número de combinações de graus de liberdade e a tábua VI pode ser usada para interpolar com uma aproximação razoável os valores que faltam.

8. Além dêstes testes, que tomam em consideração apenas as extremidades das distribuições de acaso, podemos empregar os testes da distribuição inteira, comparando pelo $\chi^{2}$ teste as frequências dos desvios relativos, observados nos experimentos, com as frequências ideais das respectivas distribuições do acaso. Como é de regra geral, esta comparação apenas pode ser feita quando o número de desvios comparados em conjunto fôr maior do que 30 ou 50.

9. O emprêgo das novas tábuas é explicado com a ajuda de dados experimentais.

10. Um dêstes exemplos serve ainda para ilustrar um outro princípio importante. Uma vez que o êrro "standard" é também uma função das dimensões das variáveis e da sua média, não podemos comparar diretamente os erros "standard" de amostras de dimensões diferentes. Deve-se aplicar nestes casos o índice da variância, que pode ser definido, ou como a raiz quadrada do quociente entre a variância e a média, ou como o quociente do êrro "standard" e da raiz quadrada da média (Brieger, 3). 


\section{SUMMARY}

1) The present paper represents a continuation and complement to a previous publication (Brieger 4) in which I explained the mathematical relations between the four most important types of chance distributions. While carrying out a large number of statistical analysis, of genetical and agricultural experiments, I came to the conclusion that the existing tables for the limits of chance distributions (Fisher and Yates, 7, Snedecor, 8, Brieger 2) are not satisfactory in three repects.

a) The tables of Fisher and Yates and of Snedecor give the limits of the t-test and of the $z$ or $\mathbf{F}$-test with different systems of ordinates ; $b$ ) there are only tables for bilateral limits of $t$ (Student) and for unilateral limits of $z$ (Fisher), $F$ (Snedecor) or theta (Brieger); c) the tables contain only values for a limited number of degrees of freedom without an auxiliary table for interpolation.

The tables, included here, are calculated in such a way as to avoid these objections.

2) The basic value for all of the new tables is the relative deviate, which may be either simple or compound :

A simple relative deviate is the quotient of a difference between a variate and its ideal value which generally is the mean divided by the respective standard error.

When comparing several deviates simultaneously, we unite them in one balanced mean estimate which is the square root of the mean square deviate (the sum of the squares of deviates divided by their degree of freedom). This value divided by the best estimate of the respective standard error is the compound relative deviate.

The four main types of chance distributions may be defined mathematically in such a form that the relative deviates form the abscissa and their frequencies the ordinates, as shown in the preceding publications (Brieger 4).

Simple relative deviates follow Students' distribution when the degree of freedom of the divisor is small (t-test) and the Gaussean distribuition (delta-test) when the degree of freedom is infinitely large, accepting as a reasonable aproximation to infinity a value bigger than 100 .

Relative compound deviates, on the other side, follow either Fisher's or Pearson's distribution, when the degree of freedom of the dividend is bigger than one and that of the divisor is either a limited or unlimited value (theta-test).

3) I explained (4) in scme detail that the three tests, called the z-test (Fisher) the F-test (Snedecor) and the theta-test (Brieger) are to a certain extent identical. Mathematically, the difference consists in the use, during integration of the basic equations for the chance distribution, of different basic values: the natural logarithm $(\mathrm{z})$, the square (F) of the deviate, or the deviate itself (theta). All the three forms of the test serve equally efficient to prove if a value of the relative deviate is significant or not.

The theta-test has an additional advantage : the quotient theta has a concrete significance and indicates how much bigger or smaller is the variability measured by the dividend of the relative deviate, in comparison with that of the divisor. Thus for instance in agricultural experiments, we may know the actual increase of basic variability due to soil heterogeneity or treatments, or in genetical and selection experiments how much more heterogeneous are some families than others.

Finally it is of considerable advantage that all tests can be executed on the same basis, using only terms of the same dimension, and not combining simple values, squares and natural logarithmes. The uniformity helps a good deal, for students and not specialised research worker to understand the testes.

4) Another important point is the necessity of using unilateral or bilatera] limits. The basic difference between these two is explained in some detail.

While testing differences, by the t-test, we may not always be interested in values with can have either posivitive or negative signes (bilateral limits), but may want to know only which varieties, treatments etc., are better and more produtive than others. Thus we are interested only in positive differences and should apply unilateral superior limits. In other experiments, we may want to eliminate only the inferior varieties and have thus to use the unilateral inferior limits of $t$, in order to identifiy the respective undesirable values. 
In most agricultural experiments we want to know wether varietal differences special treatments or soil heterogeneity increase the inevitable, experimental or residual variability. Thus we have to use while executing the theta, z-or F-test the unilateral limits, given in all tables published up to now. We are not interested in any possibility which may cause a reduction of the residual variability.

In many genetical and selection experiments we are interested in selecting families with a medium variability, which are neither extremely heterogeneous nor too uniform. Thus we whould use bilateral limits in the execution of the theta or similar tests.

5) We have found a great inconvenience in the absence of any specified recomendations with regards to the limits of probability or precision which one should choose for statistical tests. For some time it has been the custom to use, as a limit, values of three times the standard error of the normal a Gaussean distribuition which corresponds to a probability of $1: 1000(1 \%)$ or of three times the probable error, corresponding to a probability of about 1:20 $(5 \%)$, in the Gaussean distribuition. Following R. A. Fisher many authors accept the latter limit in modern tests.

For reasons, explained elsewhere, it seems to me more justified to accept simultaneously two limits : a lower one which indicates what values can be probably atributed to simple chance variation, and an upper limit to indicate those values which are "Improbable" and may be atributed to the effects of special causes. The values between these limits are considered as doubtfull, and may be atributed or to chance variation or to other causes.

I have found it convenient to use an empirical formula to define these two limits : Making $\mathrm{N}$ comparisons simultaneously, the probability limit will be equal to $1: 5 \mathrm{~N}$ and the improbability limit to $1: 10 \mathrm{~N}$, while the "region of doubt" lies between these values. The conventional limit of $5 \%, 1 \%$ and $1 \%$ should be choosen in each case, selecting values nearest to the calculated limit (Tábua XII).

6) The relations betweem $\chi^{2}$ and the relative deviate $\mathbf{D}$ are explained, as wel as the possibility of pratical applications of these relations (Tábua $\mathrm{X}$ ).

In uniformity tests when comparing a number of individual errors with a general estimate, based on a very large number of degrees of freedom, the individual quotients $\mathrm{D}=\sigma \mathrm{a}: \sigma \mathrm{i}$ may be transformed in a value of $\chi^{2}=\mathrm{n}_{\mathfrak{3}} \mathrm{D}^{2}$ and these values $\chi^{2}$ added up into a total $\chi^{2}=\sum \operatorname{nn} 1 D^{2}$.

When analysing values of $\chi^{2}$ based on more than 30 degrees of freedom it may be convenient to transform them into relative deviates by dividing by their degrees of freedon, extracting the square root and than using the tables II and IV with $n_{1}=n\left(\chi^{2}\right)$ and $\mathrm{n} 2=$ infinite.

The new tables included were calculated with great care. A large number of limits of $\boldsymbol{t}$ and theta were calculated directly using the formulas given in the beginning of this publ cation. Many values contained in Fisher's original tables were recalculeted and a close agrecement up to six decimals was found. Calculated data were than used as a starting point for algebrical interpolation of the other values, while graphic representations were used as final controll.

An auxiliarly table was included which permitts the interpolation for combination of degrees of freedom not given directly in the main tables (Tábua VI).

8) The use of the new tables is explained with the help of experimental data taken from original experiments on maize (Brieger, unpublished), on Citrus (Brieger and Moreira, 5) and from results of class work (Ficus elastica, Brieger and Gurgel, unpublished). One of these experiments severs to demonstrate a special principle: the use of the variance index (Brieger, 3) which permits the comparison of standard errors of series where the variables are of different dimension. 
VoL. VI

\section{LITERATURA CITADA}

1. Brieger, F. G. Tábuas e fórmulas para Estatística, 46 págs. Cia. Melhoramentos de S. Paulo. S. Paulo. 1937.

2. Brieger, F. G. Methoden der Erforschung der Vererbungsvorgange bei Pflanzen. Handbuch Biol. Arbeitsmeth. (E. Abderhalden) IX, 3: 1183-1308. 1937.

3. Brieger, F. G. Coeficiente da variação e índice da variância. Bragantia 2: 313332. 1942.

4. Brieger, F. G. As distribuiçžes do acaso. Anais da Esc. Sup. Agr. "Luiz de Queiroz". 2: 321-392. 1945.

5. Brieger, F. G. e S. Moreira. Experiências de cavalos para Citrus II. Bragantia 5: $597-658,1945$.

6. Fisher, R. A. Statistical Methods for Research Workers. 8 th. Ed. Oliver and Boyd. London. 334 pgs. 1941.

7. Fisher, R. A. and Frank Yates. Statistical Tables, for Biological, Agricultural and Medical Research Second Edition. Oliver and Boyd Ltd. London. 98 pgs. 1943.

8. Snedecor, G. W. Statistical Methods. Collegiate Press. Ames. Iowa. 1937.

9. Yule, G. U. and M. G. Kendall. An Introduction to The Theory of Statistical. Charles Griffin 12 th. 570 pgs. 1940. 
QUADRO I

FOLHAS DE FICUS ELASTICA (COMPRIMENTO EM mm).

Comparação das médias

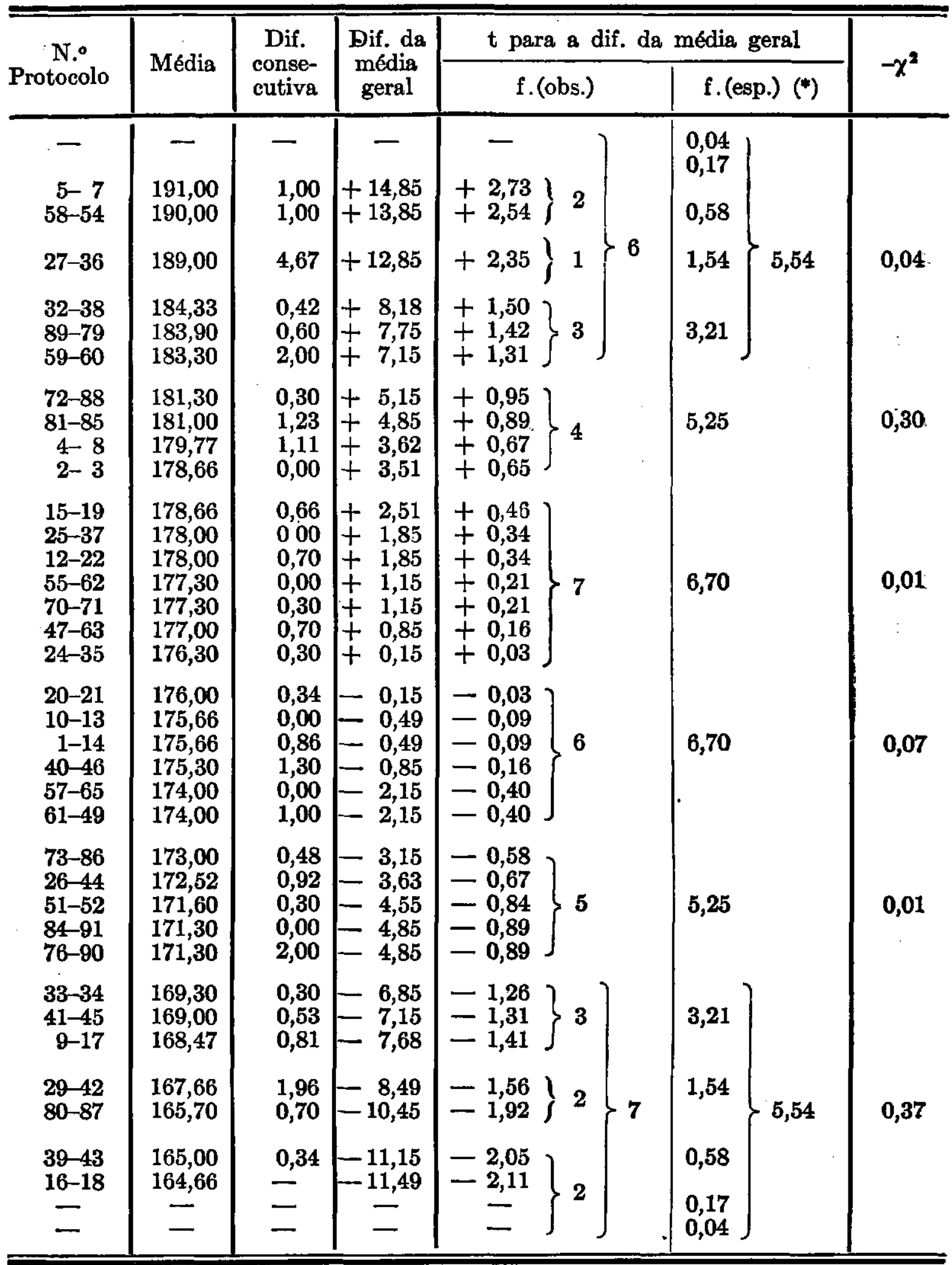

(*) As frequências esperadas foram calculadas, empregando-se as frequências da digtribuição de Gauss, para intervalos de 0,5 e multiplicando os valores da tábua VIII por 35. 


\section{QUADRO II}

VARIAÇÃO DO COMPRIMENTO DAS FOOLHAS EM FICUS ELASTICA

\begin{tabular}{|c|c|c|c|c|c|c|c|}
\hline \multirow{2}{*}{$\begin{array}{l}\text { N. }{ }^{\circ} \text { do } \\
\text { protocolo }\end{array}$} & \multirow{2}{*}{$\begin{array}{c}\text { Êrro } \\
\text { "standard" }\end{array}$} & \multirow{2}{*}{ D } & \multicolumn{4}{|c|}{ Êrro individual : êrro dentro $= \pm 25,24$} & \multirow[b]{2}{*}{$\chi^{2}$} \\
\hline & & & Fre & a obs. & Frequ & $\operatorname{esp.}\left({ }^{*}\right)$ & \\
\hline & & & & & $\begin{array}{l}0,1 \\
0,4\end{array}$ & & \\
\hline $\begin{array}{l}32-38 \\
70-71 \\
29-42\end{array}$ & $\begin{array}{l} \pm \quad 33,83 \\
\pm \quad 33,76 \\
\pm \quad 32,28\end{array}$ & $\begin{array}{ll} \pm & 1,34 \\
\pm & 1,34 \\
\pm & 1,28\end{array}$ & 3 & 7 & 1,3 & 5,2 & 0,62 \\
\hline $\begin{array}{l}61-49 \\
57-65 \\
51-52 \\
89-79\end{array}$ & $\begin{array}{ll} \pm & 31,32 \\
\pm & 30,92 \\
\pm & 30,15 \\
\pm & 29,06\end{array}$ & $\begin{array}{l} \pm 1,24 \\
\pm \quad 1,23 \\
\pm \quad 1,19 \\
\pm 1,15\end{array}$ & 4 & & 3,4 & & \\
\hline $\begin{array}{r}1-14 \\
47-63 \\
16-18 \\
24-35 \\
27-36\end{array}$ & $\begin{array}{l} \pm \quad 28,06 \\
\pm \quad 28,29 \\
\pm \quad 27,58 \\
\pm \quad 27,24 \\
\pm \quad 26,86\end{array}$ & $\begin{array}{l} \pm 1,14 \\
\pm \quad 1,13 \\
\pm 1,08 \\
\pm 1,09 \\
\pm 1,06\end{array}$ & 5 & & 6,6 & & 0,38 \\
\hline $\begin{array}{l}59-60 \\
20-21 \\
25-37 \\
15-19 \\
81-85\end{array}$ & $\begin{array}{l} \pm \quad 26,05 \\
\pm \quad 25,72 \\
\pm \quad 24,56 \\
\pm \quad 24,30 \\
\pm \quad 24,26\end{array}$ & $\begin{array}{ll} \pm & 1,03 \\
\pm & 1,02 \\
\pm & 0,97 \\
\pm & 0,96 \\
\pm & 0,96\end{array}$ & 5 & & 9,0 & & 1,78 \\
\hline $\begin{array}{r}58-54 \\
4-8 \\
2-3 \\
76-90 \\
5-7 \\
9-17 \\
33-34 \\
10-13 \\
84-91\end{array}$ & $\begin{array}{cc} \pm & 33,32 \\
\pm & 23,28 \\
\pm & 23,05 \\
\pm & 23,04 \\
\pm & 22,61 \\
\pm & 22,24 \\
\pm & 21,97 \\
\pm & 21,85 \\
\pm & 21,62\end{array}$ & $\begin{array}{ll} \pm & 0,92 \\
\pm & 0,92 \\
\pm & 0,91 \\
\pm & 0,91 \\
\pm & 0,896 \\
\pm & 0,88 \\
\pm & 0,87 \\
\pm & 0,87 \\
\pm & 0,86\end{array}$ & 9 & & 7,9 & & 0,15 \\
\hline $\begin{array}{l}73-86 \\
72-88 \\
80-87 \\
40-46\end{array}$ & $\begin{array}{l} \pm \quad 21,07 \\
\pm \quad 20,87 \\
\pm \quad 20,12 \\
\pm \quad 19,66\end{array}$ & $\begin{array}{ll} \pm & 0,83 \\
\pm & 0,83 \\
\pm & 0,797 \\
\pm & 0,78\end{array}$ & 4 & & 4,6 & & \\
\hline $\begin{array}{l}26-44 \\
12-22 \\
56-62 \\
39-43 \\
41-45\end{array}$ & 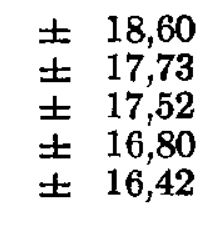 & $\begin{array}{ll} \pm & 0,74 \\
\pm & 0,70 \\
\pm & 0,69 \\
\pm & 0,67 \\
\pm & 0,6505\end{array}$ & 5 & & $\begin{array}{l}1,6 \\
0,3\end{array}$ & & \\
\hline \multicolumn{3}{|c|}{ Soma. } & 35 & & \multicolumn{2}{|c|}{35,2} & 4,13 \\
\hline
\end{tabular}

$\left(^{*}\right)$ As frequências esperadas foram calculadas, empregando-se as frequências da distribuição de Pearson com $\mathrm{n} 1=20$; $\mathrm{n} 2=$ inf. (Tábua XI) multiplicadas por 35 . 


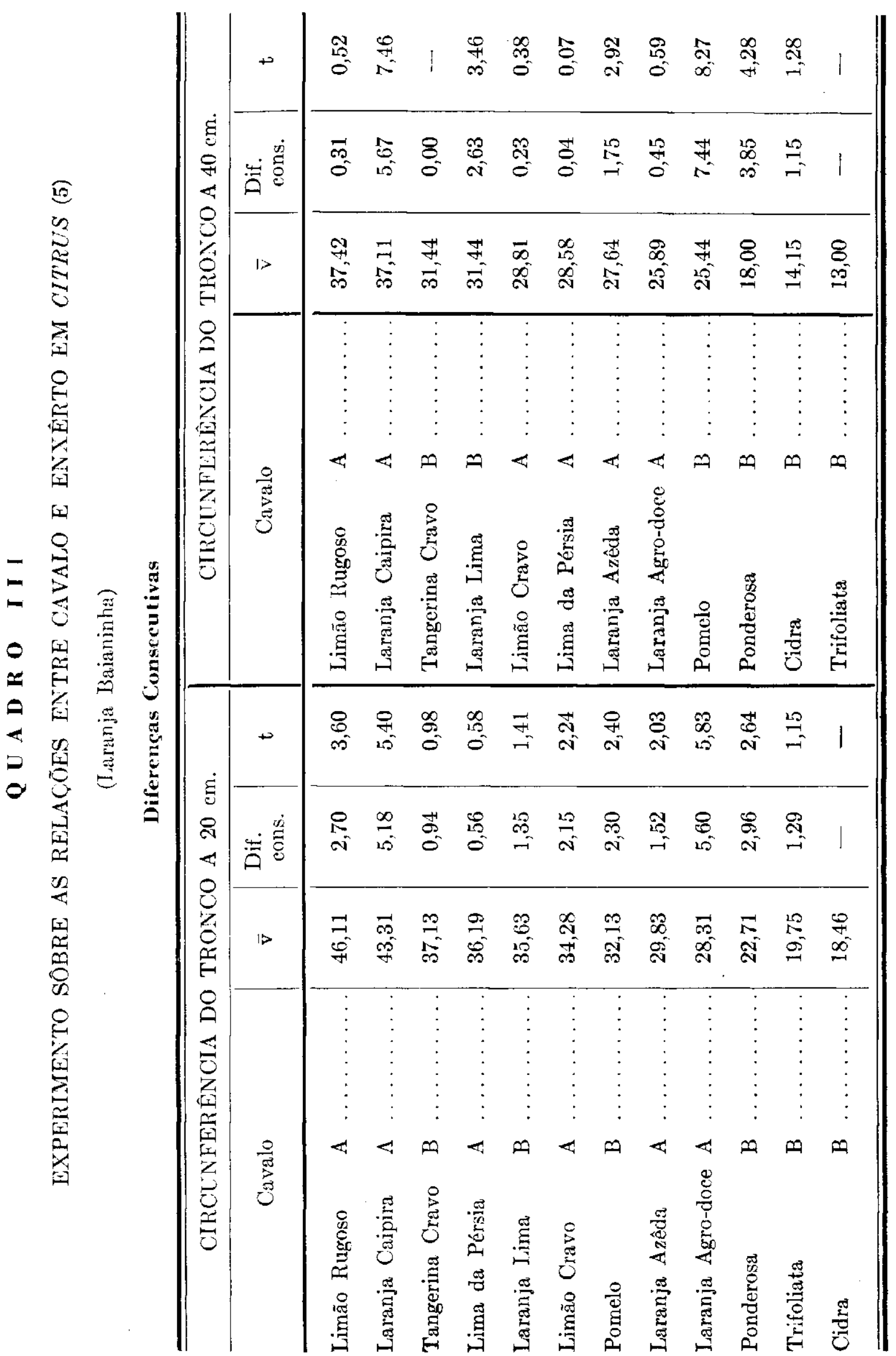


VoL. T

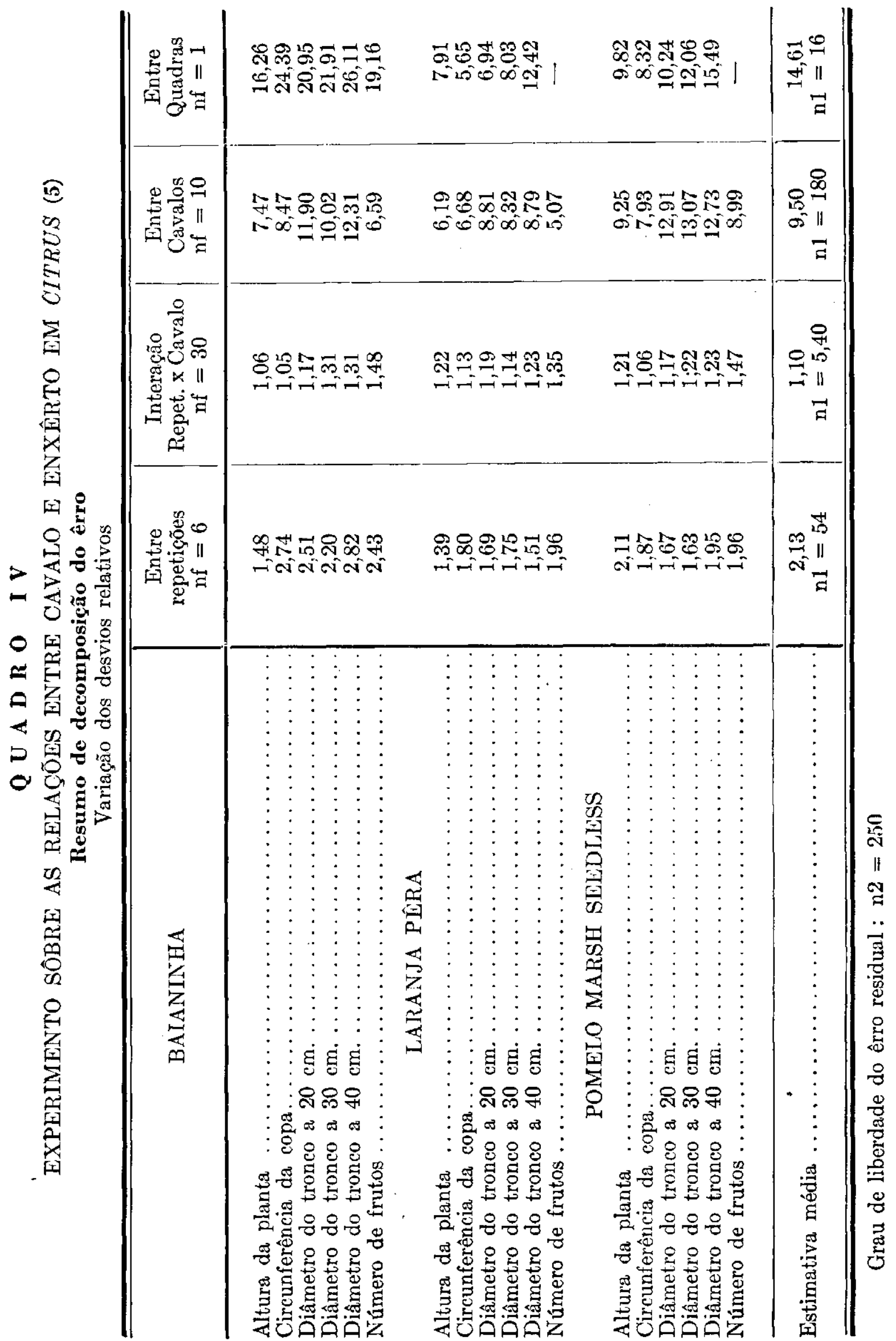




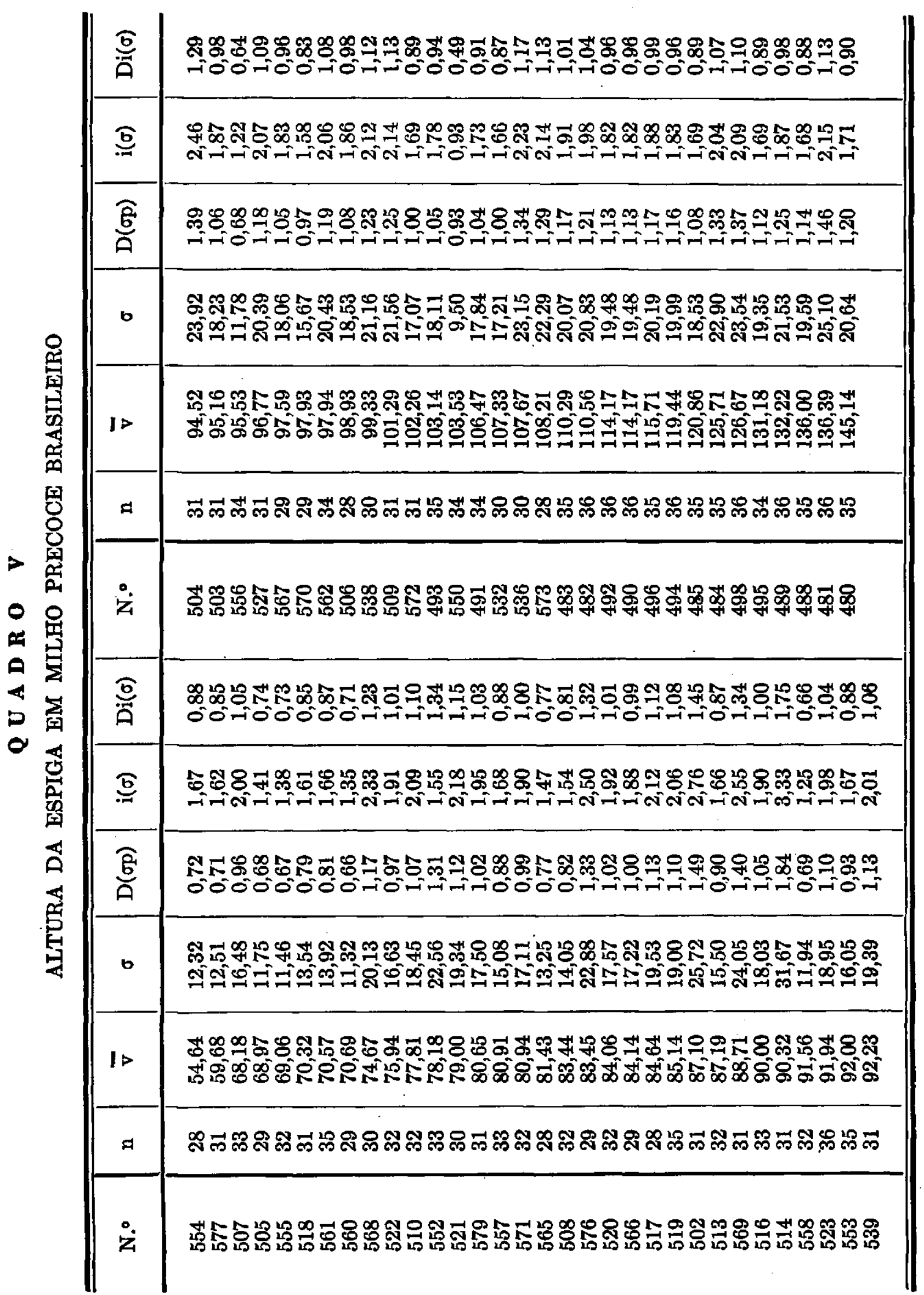




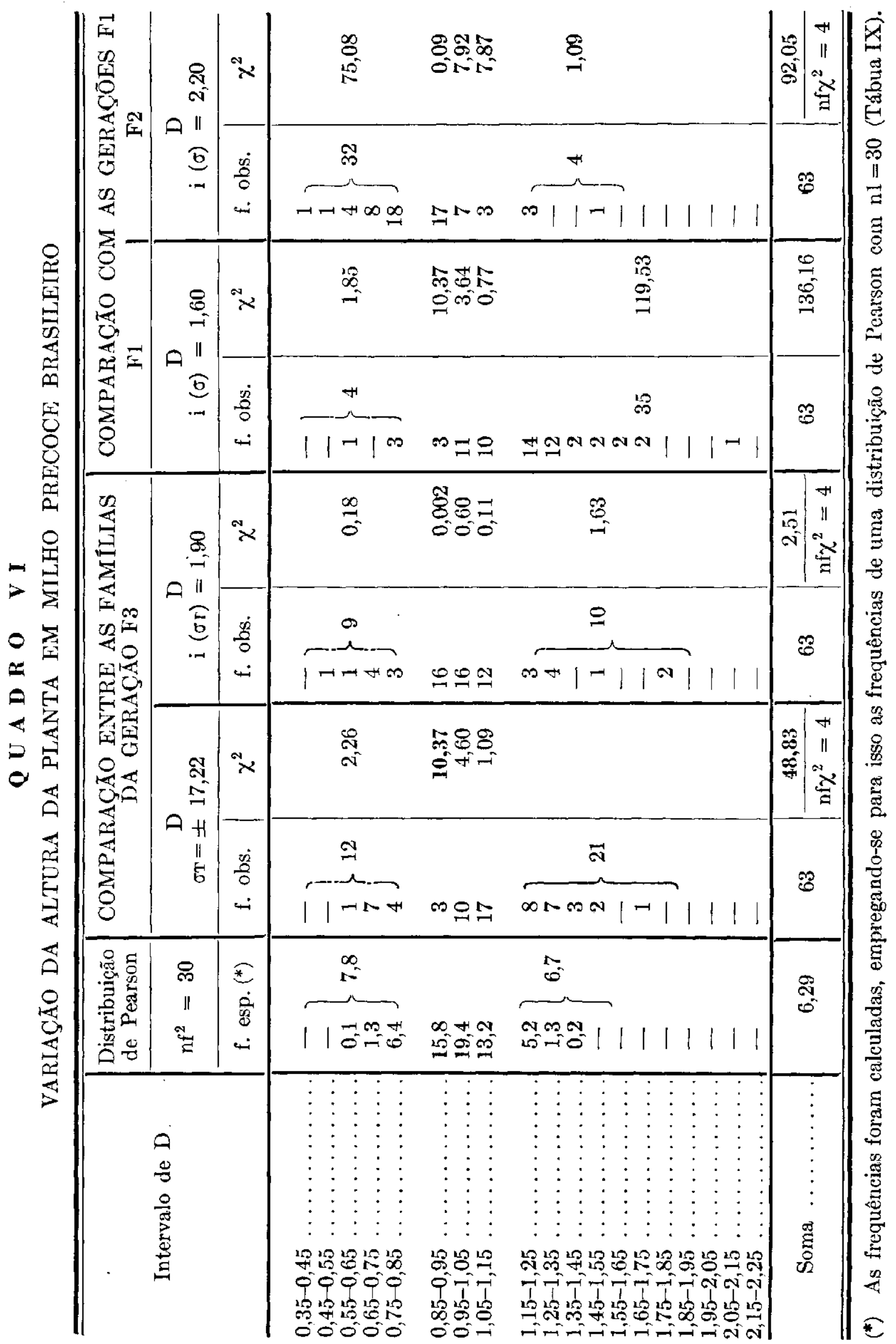




\section{EXPLICAC̄̃̃o DAS TÁBUAS}

I) - Limites unilaterais e bilaterais das distribuições de Student : t-teste.

II até V) - Limites unilaterais e bilaterais das distribuições de Fisher e Pearson para o teta-teste.

Para a execução do z-teste de Fisher usam-se os logarítmos naturais dos limites dados nas tábuas.

Para a execução do F-teste de Snedecor usam-se os quadrados dos limites dados nas tábuas.

Para a execução do $\chi^{2}$-teste de Pearson usam-se os valores da Gltima linha das tábuas; IIc, IId e IVa, correspondendo ao grau de liberdade nf2 =infinito e empregando os quadrados dos valores das tábuas, multiplicados pelo valor de nf1.

VI) - Tábua auxiliar para a interpolação.

VII-VIII) - Àreas de intervalos da distribuição de Gauss.

IX) - Ãreas de intervalos de algumas distribuições de Pearson.

X) - Limites unilaterais de $\chi^{2}$ e de D para $\mathrm{n} 2=$ infinito.

XI) - Limites de precisão.

\section{EXPLICATIONS OF TABLES}

I - Unilateral and bilateral limits of Student's distribuitions (t-test), for the analysis of differences.

II to IV - Unilateral and bilateral limits of Fisher's distribuitions and of Pearson's distribuitions (theta-test) for the analysis of error ratios.

The value of $z$ (Fisher) is the natural logarithme of the corresponding values in our tables of theta. of theta.

The value of $F$ (Snedecor) is the square of the corresponding values in our tables

When using these tables in the $\mathrm{X}^{2}$-test, one should take the botton row with $\mathrm{nf2}$ equal to infinite. The limits of $\mathrm{X}^{2}$ are equal to the squares of the limits given in the table, multiplied by their degree of freedom (nf1).

$\mathbf{v}$ - Auxiliary table for curvilinear interpolation of tables II to IV. intervalls.

VII-VIII - Ordenates and areas of the Gaussean distribuition, for different error

IX - Ordenates and areas of some of Pearson's distribuitions.

$\mathbf{X}-$ Unilateral limits of $\mathbf{X}^{2}$ and of the corresponding relative deviates.

XI - Limits of precision as functions of the number of simultaneous comparisons. 
TÂBUA I

LIMITES DAS DISTRIBUIÇÕES DE STUDENT

(t-teste)

\begin{tabular}{|c|c|c|c|c|c|c|c|}
\hline \multirow{2}{*}{$n f$} & \multicolumn{3}{|c|}{ UNILATERAIS } & \multicolumn{3}{|c|}{ BILATERAIS } & \multirow{2}{*}{ nf } \\
\hline & $5 \%$ & $1 \%$ & $0,1 \%$ & $5 \%$ & $1 \%$ & $0,1 \%$ & \\
\hline 2 & 2,92 & 6,96 & 22,22 & 4,30 & 9,92 & 31,60 & 2 \\
\hline 3 & 2,42 & 5,16 & 10,95 & 3,18 & 5,84 & 12,94 & 3 \\
\hline 4 & 2,14 & 3,96 & 7,95 & 2.78 & 4,60 & 8,61 & 4 \\
\hline 5 & 2,02 & 3,36 & 5,82 & 2,57 & 4,03 & 6,86 & 5 \\
\hline 6 & 1,94 & 3,13 & 5,15 & 2,48 & 3,71 & 5,96 & 6 \\
\hline 7 & 1,89 & 3,00 & 4.77 & 2,36 & 3.50 & 5,40 & 7 \\
\hline 8 & 1,86 & 2,90 & 4,50 & 2,31 & 3,36 & 5,04 & 8 \\
\hline 9 & 1,83 & 2,82 & 4,80 & 2,26 & 3,25 & 4,78 & 9 \\
\hline 10 & 1,81 & 2,76 & 4,14 & 2,23 & 3,17 & 4,59 & 10 \\
\hline 11 & 1,79 & 2,71 & 4,02 & 2,20 & 3,11 & 4,44 & 11 \\
\hline 12 & 1,78 & 2,67 & 3,93 & 2,18 & 3,06 & 4,32 & 12 \\
\hline 13 & 1,77 & 2,64 & 3,86 & 2,16 & 3,01 & 4,22 & 13 \\
\hline 14 & 1,76 & 2,62 & 3,80 & 2,14 & 2,98 & 4,14 & 14 \\
\hline 15 & 1,75 & 2,60 & 3,75 & 2,13 & 2,95 & 4,07 & 15 \\
\hline 16 & 1,74 & 2,58 & 3,70 & 2,12 & 2,92 & 4,02 & 16 \\
\hline 17 & 1,74 & 2,56 & 3,66 & 2,11 & 2,90 & 3,97 & 17 \\
\hline 18 & 1,73 & 2,55 & 3,62 & 2,10 & 2,89 & 3,92 & 18 \\
\hline 19 & 1,73 & 2,54 & 3,58 & 2,09 & 2,86 & 3,88 & 19 \\
\hline 20 & 1,72 & 2,53 & 3,55 & 2,09 & 2,84 & 3,85 & 20 \\
\hline 21 & 1,72 & 2,52 & 3,52 & 2,08 & 2,83 & 3,82 & 21 \\
\hline 22 & 1,72 & 2,51 & 3,49 & 2,07 & 2,82 & 3,79 & 22 \\
\hline 23 & 1,71 & 2,50 & 3,47 & 2,07 & $2,-1$ & 3,77 & 23 \\
\hline 24 & 1,71 & 2,49 & 3,45 & 2,06 & 2,80 & 3,74 & 24 \\
\hline 25 & 1,71 & 2,49 & 3,43 & 2,06 & 2,79 & 3,72 & 25 \\
\hline 26 & 1,71 & 2,48 & 3,42 & 2,06 & 2,78 & 3,71 & 26 \\
\hline 27 & 1,70 & 2,47 & 3,41 & 2,05 & 2,77 & 3,69 & 27 \\
\hline 28 & 1,70 & 2,46 & 3,40 & 2,05 & 2,76 & 3,67 & 28 \\
\hline 29 & 1,70 & 2,46 & 3,39 & 2,04 & 2,75 & 3,66 & 29 \\
\hline 30 & 1,70 & 2,46 & 3,39 & 2,04 & 2,75 & 3,65 & 30 \\
\hline 40 & 1,69 & 2,42 & 3,33 & 2,02 & 2,70 & 3,55 & 40 \\
\hline 50 & 1,68 & 2,39 & 3,28 & 2,01 & 2,66 & 3,50 & 50 \\
\hline 100 & 1,66 & 2,36 & 3,17 & 1,99 & 2,63 & 3,39 & 100 \\
\hline 500 & 1,65 & 2,34 & 3,12 & 1,97 & 2,60 & 3,33 & 500 \\
\hline inf. & 1,65 & 2,33 & 3,09 & 1,96 & 2,58 & 3,29 & inf. \\
\hline
\end{tabular}


T Á B U A

LIMITES UNIIATERAIS DAS

(Teta-

\begin{tabular}{|c|c|c|c|c|c|c|c|c|c|c|c|c|c|c|}
\hline $\mathrm{P}^{3}$ & $\downarrow^{\mathrm{nf2} 2}$ & 12 & 11 & 10 & 9 & 8 & 7 & 6 & 5 & 4 & 3 & 2 & 1 & $\stackrel{n f 1}{\longleftarrow}$ \\
\hline $\begin{array}{r}0,1 \% \\
1 \% \\
5 \%\end{array}$ & 1 & $\begin{array}{l}0,23 \\
0,33 \\
0,46\end{array}$ & $\begin{array}{l}0,23 \\
0,32 \\
0,45\end{array}$ & $\begin{array}{l}0,22 \\
0,32 \\
0,45\end{array}$ & $\begin{array}{l}0,21 \\
0,31 \\
0,44\end{array}$ & $\begin{array}{l}0,20 \\
0,30 \\
0,43\end{array}$ & $\begin{array}{l}0,19 \\
0,29 \\
0,42\end{array}$ & $\begin{array}{l}0,17 \\
0,27 \\
0,41\end{array}$ & $\begin{array}{l}0,15 \\
0,25 \\
0,39\end{array}$ & $\begin{array}{l}0,12 \\
0,22 \\
0,36\end{array}$ & $\begin{array}{l}0,08 \\
0,17 \\
0,31\end{array}$ & $\begin{array}{l}0,03 \\
0,10 \\
0,23\end{array}$ & $\begin{array}{l}0,002 \\
0,016 \\
0,083\end{array}$ & 1 \\
\hline $\begin{array}{r}0,1 \% \\
1 \% \\
5 \%\end{array}$ & 2 & $\begin{array}{l}0,28 \\
0,38 \\
0,51\end{array}$ & $\begin{array}{l}0,27 \\
0,37 \\
0,50\end{array}$ & $\begin{array}{l}0,26 \\
0,36 \\
0,49\end{array}$ & $\begin{array}{l}0,25 \\
0,35 \\
0,49\end{array}$ & $\begin{array}{l}0,23 \\
0,34 \\
0,47\end{array}$ & $\begin{array}{l}0,22 \\
0,32 \\
0,46\end{array}$ & $\begin{array}{l}0,19 \\
0,30 \\
0,44\end{array}$ & $\begin{array}{l}0,17 \\
0,27 \\
0,41\end{array}$ & $\begin{array}{l}0,13 \\
0,24 \\
0,38\end{array}$ & $\begin{array}{l}0,08 \\
0,18 \\
0,32\end{array}$ & $\begin{array}{l}0,03 \\
0,10 \\
0,23\end{array}$ & $\begin{array}{l}0.001 \\
0,014 \\
0,077\end{array}$ & 2 \\
\hline $\begin{array}{r}0,1 \% \\
1 \% \\
5 \%\end{array}$ & 3 & $\begin{array}{l}0,30 \\
0,41 \\
0,53\end{array}$ & $\begin{array}{l}0,29 \\
0,40 \\
0,53\end{array}$ & $\begin{array}{l}0,28 \\
0,39 \\
0,52\end{array}$ & $\begin{array}{l}0,27 \\
0,38 \\
0,52\end{array}$ & $\begin{array}{l}0,25 \\
0,36 \\
0,30\end{array}$ & $\begin{array}{l}0,23 \\
0,34 \\
0,48\end{array}$ & $\begin{array}{l}0,21 \\
0,32 \\
0,46\end{array}$ & $\begin{array}{l}0,17 \\
0,29 \\
0,43\end{array}$ & $\begin{array}{l}0,13 \\
0,24 \\
0,39\end{array}$ & $\begin{array}{l}0,08 \\
0,18 \\
0,33\end{array}$ & $\begin{array}{l}0,03 \\
0,10 \\
0,23\end{array}$ & $\begin{array}{l}0,001 \\
0,014 \\
0,071\end{array}$ & 3 \\
\hline $\begin{array}{r}0,1 \% \\
1 \% \\
5 \%\end{array}$ & 4 & $\begin{array}{l}0,32 \\
0,43 \\
0,56\end{array}$ & $\begin{array}{l}0,31 \\
0,42 \\
0,55\end{array}$ & $\begin{array}{l}0,30 \\
0,41 \\
0,54\end{array}$ & $\begin{array}{l}0,28 \\
0,40 \\
0,52\end{array}$ & $\begin{array}{l}0,26 \\
0,38 \\
0,51\end{array}$ & $\begin{array}{l}0,24 \\
0,36 \\
0,49\end{array}$ & $\begin{array}{l}0,21 \\
0,33 \\
0,47\end{array}$ & $\begin{array}{l}0,18 \\
0,30 \\
0,44\end{array}$ & $\begin{array}{l}0,14 \\
0,25 \\
0,40\end{array}$ & $\begin{array}{l}0,08 \\
0,19 \\
0,33\end{array}$ & $\begin{array}{l}0,03 \\
0,10 \\
0,23\end{array}$ & $\begin{array}{l}0,001 \\
0,013 \\
0,071\end{array}$ & 4 \\
\hline $\begin{array}{r}0,1 \% \\
1 \% \\
5 \%\end{array}$ & 5 & $\begin{array}{l}0,33 \\
0,44 \\
0,57\end{array}$ & $\begin{array}{l}0,32 \\
0,43 \\
0,56\end{array}$ & $\begin{array}{l}0,31 \\
0,42 \\
0,55\end{array}$ & $\begin{array}{l}0,29 \\
0,41 \\
0,53\end{array}$ & $\begin{array}{l}0,27 \\
0,39 \\
0,52\end{array}$ & $\begin{array}{l}0,25 \\
0,37 \\
0,50\end{array}$ & $\begin{array}{l}0,22 \\
0,34 \\
0,48\end{array}$ & $\begin{array}{l}0,18 \\
0,30 \\
0,44\end{array}$ & $\begin{array}{l}0,14 \\
0,25 \\
0,40\end{array}$ & $\begin{array}{l}0,09 \\
0,19 \\
0,33\end{array}$ & $\begin{array}{l}0,03 \\
0,10 \\
0,23\end{array}$ & $\begin{array}{l}0,001 \\
0,013 \\
0,0667\end{array}$ & 5 \\
\hline $\begin{array}{r}0,1 \% \\
1 \% \\
5 \%\end{array}$ & 6 & $\begin{array}{l}0,34 \\
0,45 \\
0,58\end{array}$ & $\begin{array}{l}0,33 \\
0,44 \\
0,57\end{array}$ & $\begin{array}{l}0,32 \\
0,43 \\
0,56\end{array}$ & $\begin{array}{l}0,30 \\
0,42 \\
0,54\end{array}$ & $\begin{array}{l}0,28 \\
0,40 \\
0,53\end{array}$ & $\begin{array}{l}0,25 \\
0,37 \\
0,51\end{array}$ & $\begin{array}{l}0,22 \\
0,34 \\
0,48\end{array}$ & $\begin{array}{l}0,19 \\
0,31 \\
0,45\end{array}$ & $\begin{array}{l}0,14 \\
0,26 \\
0,40\end{array}$ & $\begin{array}{l}0,09 \\
0,19 \\
0,33\end{array}$ & $\begin{array}{l}0,03 \\
0,10 \\
0,23\end{array}$ & $\begin{array}{l}0,001 \\
0,013 \\
0,067\end{array}$ & 6 \\
\hline $\begin{array}{r}0,1 \% \\
1 \% \\
5 \%\end{array}$ & 7 & $\begin{array}{l}0,35 \\
0,46 \\
0,58\end{array}$ & $\begin{array}{l}0,34 \\
0,45 \\
0,57\end{array}$ & $\begin{array}{l}0,32 \\
0,44 \\
0,56\end{array}$ & $\begin{array}{l}0,31 \\
0,42 \\
0,55\end{array}$ & $\begin{array}{l}0,28 \\
0,40 \\
0,53\end{array}$ & $\begin{array}{l}0,26 \\
0,38 \\
0,51\end{array}$ & $\begin{array}{l}0,23 \\
0,35 \\
0,49\end{array}$ & $\begin{array}{l}0,19 \\
0,31 \\
0,45\end{array}$ & $\begin{array}{l}0,14 \\
0,26 \\
0,40\end{array}$ & $\begin{array}{l}0,09 \\
0,19 \\
0,34\end{array}$ & $\begin{array}{l}0,03 \\
0,10 \\
0,23\end{array}$ & $\begin{array}{l}0,001 \\
0,013 \\
0,066\end{array}$ & 7 \\
\hline $\begin{array}{r}0,1 \% \\
1 \% \\
5 \%\end{array}$ & 8 & $\begin{array}{l}0,36 \\
0,47 \\
0,59\end{array}$ & $\begin{array}{l}0,35 \\
0,46 \\
0,58\end{array}$ & $\begin{array}{l}0,33 \\
0,44 \\
0,57\end{array}$ & $\begin{array}{l}0.31 \\
0,43 \\
0,56\end{array}$ & $\begin{array}{l}0,29 \\
0,41 \\
0,54\end{array}$ & $\begin{array}{l}0,26 \\
0,38 \\
0,52\end{array}$ & $\begin{array}{l}0,23 \\
0,35 \\
0,49\end{array}$ & $\begin{array}{l}0,19 \\
0,31 \\
0,45\end{array}$ & $\begin{array}{l}0,14 \\
0,26 \\
0,41\end{array}$ & $\begin{array}{l}0,09 \\
0,19 \\
0,34\end{array}$ & $\begin{array}{l}0,03 \\
0,10 \\
0,23\end{array}$ & $\begin{array}{l}0,001 \\
0,013 \\
0,066\end{array}$ & 8 \\
\hline $\begin{array}{r}0,1 \% \\
1 \% \\
5 \%\end{array}$ & 9 & $\begin{array}{l}0,36 \\
0,48 \\
0,60\end{array}$ & $\begin{array}{l}0,35 \\
0,47 \\
0,59\end{array}$ & $\begin{array}{l}0,33 \\
0,45 \\
0,58\end{array}$ & $\begin{array}{l}0,31 \\
0,43 \\
0,56\end{array}$ & $\begin{array}{l}0,29 \\
0,41 \\
0,55\end{array}$ & $\begin{array}{l}0,26 \\
0,39 \\
0,52\end{array}$ & $\begin{array}{l}0,23 \\
0,35 \\
0,50\end{array}$ & $\begin{array}{l}0,19 \\
0,31 \\
0,46\end{array}$ & $\begin{array}{l}0,14 \\
0,26 \\
0,41\end{array}$ & $\begin{array}{l}0,09 \\
0,19 \\
0,34\end{array}$ & $\begin{array}{l}0,03 \\
0,10 \\
0,23\end{array}$ & $\begin{array}{l}0,001 \\
0.013 \\
0,066\end{array}$ & 9 \\
\hline $\begin{array}{r}0,1 \% \\
1 \% \\
5 \%\end{array}$ & 10 & $\begin{array}{l}0,37 \\
0,48 \\
0,61\end{array}$ & $\begin{array}{l}0,36 \\
0,47 \\
0,60\end{array}$ & $\begin{array}{l}0,34 \\
0,45 \\
0,58\end{array}$ & $\begin{array}{l}0,32 \\
0,44 \\
0,56\end{array}$ & $\begin{array}{l}0,29 \\
0,41 \\
0,5 \tilde{5}\end{array}$ & $\begin{array}{l}0,27 \\
0,39 \\
0,53\end{array}$ & $\begin{array}{l}0,23 \\
0,36 \\
0,50\end{array}$ & $\begin{array}{l}0,19 \\
0,32 \\
0,46\end{array}$ & $\begin{array}{l}0,14 \\
0,26 \\
0,41\end{array}$ & $\begin{array}{l}0,09 \\
0,19 \\
0,34\end{array}$ & $\begin{array}{l}0,03 \\
0,10 \\
0,23\end{array}$ & $\begin{array}{l}0,001 \\
0,013 \\
0,066\end{array}$ & 10 \\
\hline $\begin{array}{r}0,1 \% \\
1 \% \\
5 \%\end{array}$ & 11 & $\begin{array}{l}0,37 \\
0,49 \\
0,61\end{array}$ & $\begin{array}{l}0,36 \\
0,47 \\
0,60\end{array}$ & $\begin{array}{l}0,34 \\
0,46 \\
0,58\end{array}$ & $\begin{array}{l}0,32 \\
0,44 \\
0,57\end{array}$ & $\begin{array}{l}0,30 \\
0,42 \\
0,55\end{array}$ & $\begin{array}{l}0,27 \\
0,39 \\
0,53\end{array}$ & $\begin{array}{l}0,23 \\
0,36 \\
0,50\end{array}$ & $\begin{array}{l}0,19 \\
0,32 \\
0,46\end{array}$ & $\begin{array}{l}0,14 \\
0,26 \\
0,41\end{array}$ & $\begin{array}{l}0,09 \\
0,19 \\
0,34\end{array}$ & $\begin{array}{l}0,03 \\
0,10 \\
0.23\end{array}$ & $\begin{array}{l}0,001 \\
0,013 \\
0,066\end{array}$ & 11 \\
\hline $\begin{array}{r}0,1 \% \\
1 \% \\
5 \%\end{array}$ & 12 & $\begin{array}{l}0,38 \\
0,49 \\
0,61\end{array}$ & $\begin{array}{l}0,36 \\
0,48 \\
0,60\end{array}$ & $\begin{array}{l}0,34 \\
0,46 \\
0,59\end{array}$ & $\begin{array}{l}0.32 \\
(1,44 \\
0,57\end{array}$ & $\begin{array}{l}0,30 \\
0,42 \\
0,50\end{array}$ & $\begin{array}{l}0,27 \\
0,39 \\
0,53\end{array}$ & $\begin{array}{l}0,24 \\
0,36 \\
0,50\end{array}$ & $\begin{array}{l}0,19 \\
0,32 \\
0,47\end{array}$ & $\begin{array}{l}0,15 \\
0,26 \\
0,41\end{array}$ & $\begin{array}{l}0.09 \\
0.19 \\
0,34\end{array}$ & $\begin{array}{l}0,03 \\
0,10 \\
0,23\end{array}$ & $\begin{array}{l}0,001 \\
0,013 \\
0,066\end{array}$ & 12 \\
\hline $\begin{array}{r}0,1 \% \\
1 \% \\
5 \%\end{array}$ & 13 & $\begin{array}{l}0,38 \\
0,49 \\
0,61\end{array}$ & $\begin{array}{l}0,37 \\
0,48 \\
0,60\end{array}$ & $\begin{array}{l}0,35 \\
0,46 \\
0,59\end{array}$ & $\begin{array}{l}0,33 \\
0,44 \\
0,57\end{array}$ & $\begin{array}{l}0,30 \\
0,42 \\
0,56\end{array}$ & $\begin{array}{l}0,27 \\
0,40 \\
0,53\end{array}$ & $\begin{array}{l}0,24 \\
0,36 \\
0,50\end{array}$ & $\begin{array}{l}0,20 \\
0,32 \\
0,47\end{array}$ & $\begin{array}{l}0,15 \\
0,26 \\
0,41\end{array}$ & $\begin{array}{l}0,09 \\
0,19 \\
0,34\end{array}$ & $\begin{array}{l}0,03 \\
0,10 \\
0,23\end{array}$ & $\begin{array}{l}0,001 \\
0,013 \\
0,066\end{array}$ & 13 \\
\hline $\begin{array}{r}0,1 \% \\
1 \% \\
5 \%\end{array}$ & 14 & $\begin{array}{l}0,39 \\
0,50 \\
0,62\end{array}$ & $\begin{array}{l}0,37 \\
0,48 \\
0,61\end{array}$ & $\begin{array}{l}0,35 \\
0,47 \\
0,59\end{array}$ & $\begin{array}{l}0,33 \\
0,45 \\
0,57\end{array}$ & $\begin{array}{l}0,30 \\
0,42 \\
0,56\end{array}$ & $\begin{array}{l}0,27 \\
0,40 \\
0,53\end{array}$ & $\begin{array}{l}0,24 \\
0,36 \\
0,51\end{array}$ & $\begin{array}{l}0,20 \\
0,32 \\
0,47\end{array}$ & $\begin{array}{l}0,15 \\
0,27 \\
0,41\end{array}$ & $\begin{array}{l}0,09 \\
0,19 \\
0,34\end{array}$ & $\begin{array}{l}0,03 \\
0,10 \\
0,23\end{array}$ & $\begin{array}{l}0,001 \\
0,013 \\
0,066\end{array}$ & 14 \\
\hline $\begin{array}{r}0,1 \% \\
1 \% \\
5 \%\end{array}$ & 15 & $\begin{array}{l}0,39 \\
0,50 \\
0,62\end{array}$ & $\begin{array}{l}0,37 \\
0,48 \\
0,61\end{array}$ & $\begin{array}{l}0,35 \\
0,47 \\
0,59\end{array}$ & $\begin{array}{l}0,33 \\
0,45 \\
0,57\end{array}$ & $\begin{array}{l}0,30 \\
0,43 \\
0,56\end{array}$ & $\begin{array}{l}0,28 \\
0,40 \\
0,53\end{array}$ & $\begin{array}{l}0,24 \\
0,36 \\
0,51\end{array}$ & $\begin{array}{l}0,20 \\
0,32 \\
0,47\end{array}$ & $\begin{array}{l}.015 \\
0,27 \\
0,41\end{array}$ & $\begin{array}{l}0,09 \\
0,19 \\
0,34\end{array}$ & $\begin{array}{l}0,03 \\
0,10 \\
0,23\end{array}$ & $\begin{array}{l}0,001 \\
0,013 \\
0,066\end{array}$ & 15 \\
\hline $\begin{array}{r}0,1 \% \\
1 \% \\
5 \%\end{array}$ & 20 & $\begin{array}{l}0,40 \\
0,51 \\
0,63\end{array}$ & $\begin{array}{l}0,38 \\
0,50 \\
0,61\end{array}$ & $\begin{array}{l}0,36 \\
0,47 \\
0,60\end{array}$ & $\begin{array}{l}0,33 \\
0,46 \\
0,58\end{array}$ & $\begin{array}{l}0,31 \\
0,43 \\
0,56\end{array}$ & $\begin{array}{l}0,28 \\
0,40 \\
0,54\end{array}$ & $\begin{array}{l}0,24 \\
0,37 \\
0,31\end{array}$ & $\begin{array}{l}0,20 \\
0,32 \\
0,47\end{array}$ & $\begin{array}{l}0,15 \\
0,27 \\
0,41\end{array}$ & $\begin{array}{l}0,09 \\
0,19 \\
0,34\end{array}$ & $\begin{array}{l}0,03 \\
0,10 \\
0,23\end{array}$ & $\begin{array}{l}0,001 \\
0,013 \\
0,066\end{array}$ & 20 \\
\hline$P$ & $\uparrow_{\mathrm{nf} 2}$ & 12 & 11 & 10 & 9 & 8 & 7 & 6 & 5 & 4 & 3 & 2 & 1 & $\longleftarrow$ \\
\hline
\end{tabular}


I I a

DISTRIBUIÇÕES DE FISHER

teste)

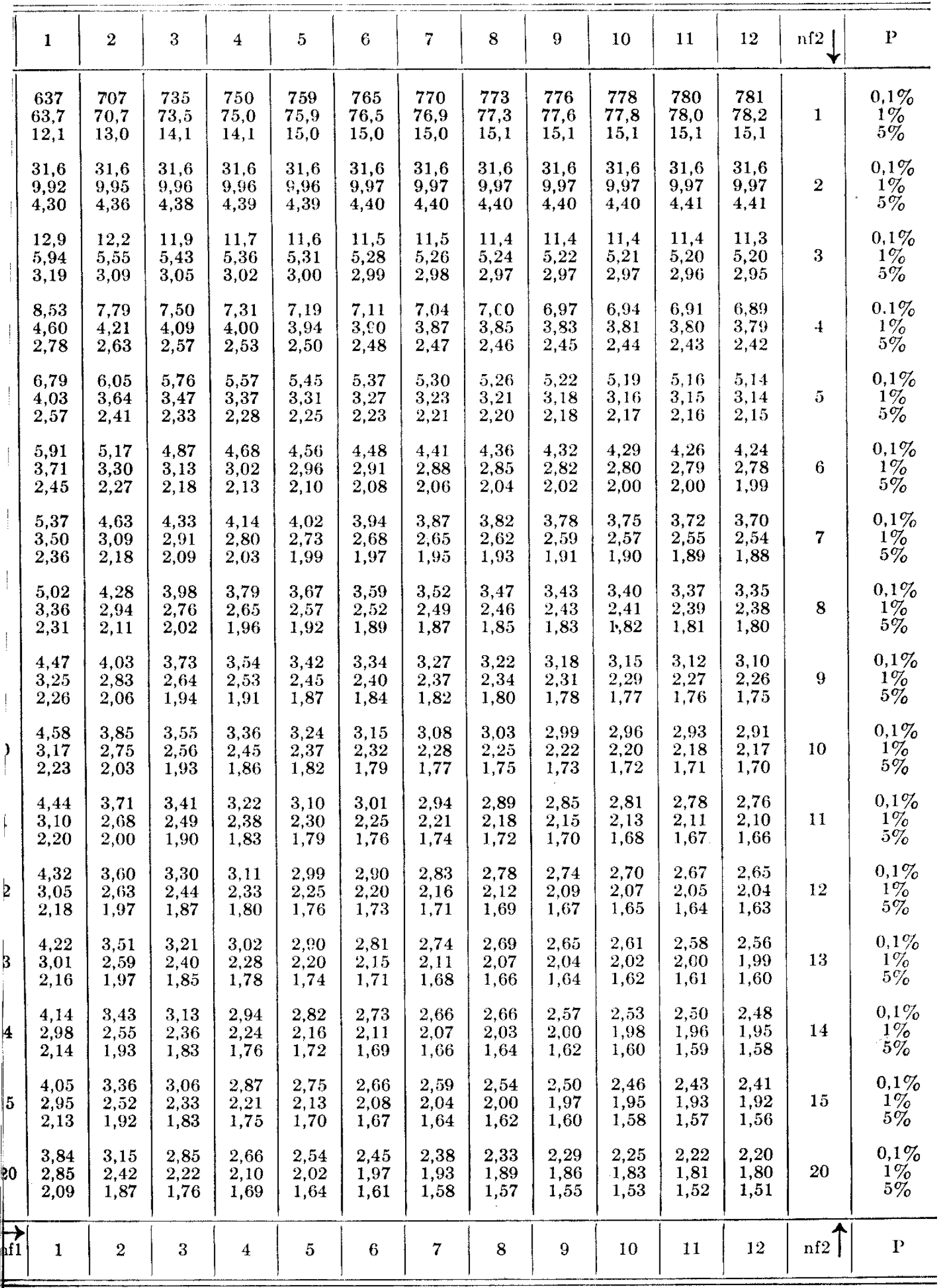


T Á B U A

LIMITES UNILATERAIS DAS

(Teta-

\begin{tabular}{|c|c|c|c|c|c|c|c|c|c|c|c|c|c|c|c|}
\hline $\mathrm{P}$ & $\downarrow^{\text {nf2 }}$ & $\inf$ & 100 & 75 & 50 & 45 & 40 & 35 & 30 & 25 & 20 & 15 & 14 & 13 & $\stackrel{\text { nf } 1}{\leftarrow}$ \\
\hline $\begin{array}{c}0,1 \% \\
1 \% \\
5 \%\end{array}$ & 1 & $\begin{array}{l}0,30 \\
0,39 \\
0,51\end{array}$ & $\begin{array}{l}0,29 \\
0,38 \\
0,51\end{array}$ & $\begin{array}{l}0,29 \\
0,37 \\
0,50\end{array}$ & $\begin{array}{l}0,29 \\
0,37 \\
0,50\end{array}$ & $\begin{array}{l}0,28 \\
0,37 \\
0,50\end{array}$ & $\begin{array}{l}0,28 \\
0,37 \\
0,50\end{array}$ & $\begin{array}{l}0,28 \\
0,37 \\
0,49\end{array}$ & $\begin{array}{l}0,27 \\
0,36 \\
0,49\end{array}$ & $\begin{array}{l}0,27 \\
0,36 \\
0,49\end{array}$ & $\begin{array}{l}0,26 \\
0,35 \\
0,48\end{array}$ & $\begin{array}{l}0,25 \\
0,34 \\
0,47\end{array}$ & $\begin{array}{l}0,24 \\
0,34 \\
0,47\end{array}$ & $\begin{array}{l}0,24 \\
0,33 \\
0,46\end{array}$ & 1 \\
\hline $\begin{array}{c}0,1 \% \\
1 \% \\
5 \%\end{array}$ & 2 & $\begin{array}{l}0,38 \\
0,47 \\
0,58\end{array}$ & $\begin{array}{l}0,37 \\
0,45 \\
0,57\end{array}$ & $\begin{array}{l}0,36 \\
0,45 \\
0,56\end{array}$ & $\begin{array}{l}0,35 \\
0,44 \\
0,56\end{array}$ & $\begin{array}{l}0,35 \\
0,44 \\
0,56\end{array}$ & $\begin{array}{l}0,35 \\
0,44 \\
0,56\end{array}$ & $\begin{array}{l}0,3 \cdot 4 \\
0,43 \\
0,55\end{array}$ & $\begin{array}{l}0,34 \\
0,43 \\
0,55\end{array}$ & $\begin{array}{l}0,33 \\
0,42 \\
0,53\end{array}$ & $\begin{array}{l}0,32 \\
0,41 \\
0,53\end{array}$ & $\begin{array}{l}0,30 \\
0,40 \\
0,52\end{array}$ & $\begin{array}{l}0,29 \\
0,39 \\
0,52\end{array}$ & $\begin{array}{l}0,28 \\
0,39 \\
0,51\end{array}$ & 2 \\
\hline $\begin{array}{c}0,1 \% \\
1 \% \\
5 \%\end{array}$ & 3 & $\begin{array}{l}0,43 \\
0,51 \\
0,62\end{array}$ & $\begin{array}{l}0,41 \\
0,50 \\
0,61\end{array}$ & $\begin{array}{l}0,41 \\
0,50 \\
0,61\end{array}$ & $\begin{array}{l}0,40 \\
0,49 \\
0,60\end{array}$ & $\begin{array}{l}0,39 \\
0,49 \\
0,60\end{array}$ & $\begin{array}{l}0,39 \\
0,48 \\
0,59\end{array}$ & $\begin{array}{l}\mathbf{0 , 3 8} \\
0,48 \\
0,59\end{array}$ & $\begin{array}{l}0,38 \\
0,47 \\
0,58\end{array}$ & $\begin{array}{l}0,36 \\
0,46 \\
0,57\end{array}$ & $\begin{array}{l}0,35 \\
0,45 \\
0,57\end{array}$ & $\begin{array}{l}0,33 \\
0,43 \\
0,55\end{array}$ & $\begin{array}{l}0,32 \\
0,42 \\
0, i 5\end{array}$ & $\begin{array}{l}0,31 \\
0,42 \\
0,54\end{array}$ & 3 \\
\hline $\begin{array}{c}0,1 \% \\
1 \% \\
5 \%\end{array}$ & 4 & $\begin{array}{l}0,47 \\
0,55 \\
0,65\end{array}$ & $\begin{array}{l}0,45 \\
0,53 \\
0,64\end{array}$ & $\begin{array}{l}0,44 \\
0,53 \\
0,64\end{array}$ & $\begin{array}{l}0,43 \\
0,52 \\
0,63\end{array}$ & $\begin{array}{l}0,43 \\
0,52 \\
0,62\end{array}$ & $\begin{array}{l}0,42 \\
0,51 \\
0,62\end{array}$ & $\begin{array}{l}0,41 \\
0,51 \\
0,61\end{array}$ & $\begin{array}{l}0,40 \\
0,50 \\
0,61\end{array}$ & $\begin{array}{l}0,39 \\
0,49 \\
0,60\end{array}$ & $\begin{array}{l}0,38 \\
0,48 \\
0,59\end{array}$ & $\begin{array}{l}0,35 \\
0,45 \\
0,57\end{array}$ & $\begin{array}{l}0,34 \\
0,45 \\
0,57\end{array}$ & $\begin{array}{l}0,33 \\
0,44 \\
0,56\end{array}$ & 4 \\
\hline $\begin{array}{c}0,1 \% \\
1 \% \\
5 \%\end{array}$ & 5 & $\begin{array}{l}0,50 \\
0,57 \\
0,67\end{array}$ & $\begin{array}{l}0,47 \\
0,56 \\
0,66\end{array}$ & $\begin{array}{l}0,47 \\
0,55 \\
0,65\end{array}$ & $\begin{array}{l}0,45 \\
0,54 \\
0,65\end{array}$ & $\begin{array}{l}0,45 \\
0,54 \\
0,64\end{array}$ & $\begin{array}{l}0,44 \\
0,53 \\
0,64\end{array}$ & $\begin{array}{l}0,44 \\
0,53 \\
0,63\end{array}$ & $\begin{array}{l}0,43 \\
0,52 \\
0,63\end{array}$ & $\begin{array}{l}0,41 \\
0,51 \\
0,62\end{array}$ & $\begin{array}{l}0,39 \\
0,50 \\
0,61\end{array}$ & $\begin{array}{l}0,36 \\
0,47 \\
0,59\end{array}$ & $\begin{array}{l}0,35 \\
0,46 \\
0,58\end{array}$ & $\begin{array}{l}0,34 \\
0,45 \\
0,57\end{array}$ & 5 \\
\hline $\begin{array}{c}0,1 \% \\
1 \% \\
5 \%\end{array}$ & 6 & $\begin{array}{l}0,52 \\
0,60 \\
0,69\end{array}$ & $\begin{array}{l}0,50 \\
0,58 \\
0,68\end{array}$ & $\begin{array}{l}0,49 \\
0,57 \\
0,67\end{array}$ & $\begin{array}{l}0,47 \\
0,56 \\
0,66\end{array}$ & & $\begin{array}{l}0,46 \\
0,55 \\
0,65\end{array}$ & $\begin{array}{l}0,45 \\
0,55 \\
0,65\end{array}$ & $\begin{array}{l}0,44 \\
0,54 \\
0,64\end{array}$ & $\begin{array}{l}0,43 \\
0,53 \\
0,63\end{array}$ & $\begin{array}{l}0,41 \\
0,51 \\
0,62\end{array}$ & $\begin{array}{l}0,38 \\
0,48 \\
0,60\end{array}$ & $\begin{array}{l}0,37 \\
0,47 \\
0,59\end{array}$ & $\begin{array}{l}0,36 \\
0,47 \\
0,58\end{array}$ & 6 \\
\hline $\begin{array}{c}0,1 \% \\
1 \% \\
5 \%\end{array}$ & 7 & $\begin{array}{l}0,54 \\
0,62 \\
0,70\end{array}$ & $\begin{array}{l}0,51 \\
0,59 \\
0,69\end{array}$ & $\begin{array}{l}0,50 \\
0,58 \\
0,68\end{array}$ & $\begin{array}{l}0,49 \\
0,57 \\
0,68\end{array}$ & & & $\begin{array}{l}0,47 \\
0,56 \\
0,66\end{array}$ & $\begin{array}{l}0,46 \\
0,55 \\
0,65\end{array}$ & & $\begin{array}{l}0,42 \\
0,51 \\
0,63\end{array}$ & $\begin{array}{l}0,39 \\
0,49 \\
0,61\end{array}$ & $\begin{array}{l}0,38 \\
0,48 \\
0,60\end{array}$ & & 7 \\
\hline $\begin{array}{c}0,1 \% \\
1 \% \\
5 \%\end{array}$ & 8 & $\begin{array}{l}0,55 \\
0,63 \\
0,72\end{array}$ & $\begin{array}{l}0,53 \\
0,61 \\
0,70\end{array}$ & $\begin{array}{l}0,52 \\
0,60 \\
0,70\end{array}$ & $\begin{array}{l}0,50 \\
0,59 \\
0,69\end{array}$ & & & $\begin{array}{l}0,57 \\
0,67\end{array}$ & $\begin{array}{l}0,47 \\
0,56 \\
0,66\end{array}$ & & & $\begin{array}{l}0,39 \\
0,50 \\
0,62\end{array}$ & $\begin{array}{l}0,38 \\
0,49 \\
0,61\end{array}$ & & 8 \\
\hline $\begin{array}{c}0,1 \% \\
1 \% \\
5 \%\end{array}$ & 9 & $\begin{array}{l}0,56 \\
0,65 \\
0,73\end{array}$ & $\begin{array}{l}0,54 \\
0,62 \\
0,71\end{array}$ & $\begin{array}{l}0,53 \\
0,61 \\
0,71\end{array}$ & $\begin{array}{l}0,51 \\
0,60 \\
0,70\end{array}$ & $\begin{array}{l}0,51 \\
0,60 \\
0,69\end{array}$ & & $\begin{array}{l}0,49 \\
0,58 \\
0,68\end{array}$ & $\begin{array}{l}0,48 \\
0,57 \\
0,67\end{array}$ & $\begin{array}{l}0,46 \\
0,56 \\
0,66\end{array}$ & $\begin{array}{l}0,44 \\
0,51 \\
0,65\end{array}$ & $\begin{array}{l}0,40 \\
0,51 \\
0,63\end{array}$ & $\begin{array}{l}0,39 \\
0,50 \\
0,62\end{array}$ & & 9 \\
\hline $\begin{array}{c}0,1 \% \\
1 \% \\
5 \%\end{array}$ & 10 & $\begin{array}{l}0,58 \\
0,66 \\
0,74\end{array}$ & & & & & & $\begin{array}{l}0,50 \\
0,60 \\
0,69\end{array}$ & $\begin{array}{l}0,49 \\
0,58 \\
0,68\end{array}$ & & & $\begin{array}{l}0,41 \\
0,51 \\
0,63\end{array}$ & & & 10 \\
\hline $\begin{array}{c}0,1 \% \\
1 \% \\
5 \%\end{array}$ & 11 & $\begin{array}{l}0,59 \\
0,67 \\
0,75\end{array}$ & $\begin{array}{l}0,56 \\
0,64 \\
0,73\end{array}$ & & & & & & & & & & $\begin{array}{l}0,51 \\
0,63\end{array}$ & & 11 \\
\hline $\begin{array}{c}0,1 \% \\
1 \% \\
5 \%\end{array}$ & 12 & $\begin{array}{l}0,60 \\
0,68 \\
0,75\end{array}$ & $\begin{array}{l}0,57 \\
0,65 \\
0,74\end{array}$ & $\begin{array}{l}0,56 \\
0,64 \\
0,74\end{array}$ & $\begin{array}{l}0,54 \\
0,63 \\
0,72\end{array}$ & $\begin{array}{l}0,53 \\
0,62 \\
0,72\end{array}$ & & & $\begin{array}{l}0,50 \\
0,60 \\
0,69\end{array}$ & & & $\begin{array}{l}0,41 \\
0,52 \\
0,64\end{array}$ & $\begin{array}{l}0,40 \\
0,51 \\
0,63\end{array}$ & & 12 \\
\hline $\begin{array}{c}0,1 \% \\
1 \% \\
5 \%\end{array}$ & 13 & $\begin{array}{l}0,61 \\
0,68 \\
0,76\end{array}$ & & & & & & $\begin{array}{l}0,52 \\
0,61 \\
0,70\end{array}$ & $\begin{array}{l}0,51 \\
0,60 \\
0,69\end{array}$ & & & & & & 13 \\
\hline $\begin{array}{c}0,1 \% \\
1 \% \\
5 \%\end{array}$ & 14 & $\begin{array}{l}0,63 \\
0,69 \\
0,77\end{array}$ & $\begin{array}{l}0,59 \\
0,65 \\
0,75\end{array}$ & $\begin{array}{l}0,58 \\
0,65 \\
0,75\end{array}$ & $\begin{array}{l}0,56 \\
0,63 \\
0,74\end{array}$ & $\begin{array}{l}0,56 \\
0,63 \\
0,73\end{array}$ & $\begin{array}{l}0,54 \\
0,62 \\
0,72\end{array}$ & $\begin{array}{l}0,53 \\
0,61 \\
0,71\end{array}$ & $\begin{array}{l}0,52 \\
0,60 \\
0,70\end{array}$ & & $\begin{array}{l}0,47 \\
0,56 \\
0,67\end{array}$ & $\begin{array}{l}0,43 \\
0,53 \\
0,65\end{array}$ & $\begin{array}{l}0,41 \\
0,52 \\
0,64\end{array}$ & $\begin{array}{l}0,40 \\
0,51 \\
0,63\end{array}$ & 14 \\
\hline $\begin{array}{c}0,1 \% \\
1 \% \\
5 \%\end{array}$ & 15 & $\begin{array}{l}0,64 \\
0,70 \\
0,78\end{array}$ & $\begin{array}{l}0,60 \\
0,66 \\
0,76\end{array}$ & $\begin{array}{l}0,58 \\
0,65 \\
0,74\end{array}$ & $\begin{array}{l}0,57 \\
0,64 \\
0,74\end{array}$ & $\begin{array}{l}0,56 \\
0,63 \\
0,73\end{array}$ & $\begin{array}{l}0,55 \\
0,63 \\
0,71\end{array}$ & $\begin{array}{l}0,62 \\
0,70\end{array}$ & $\begin{array}{l}0,52 \\
0,61 \\
0,69\end{array}$ & $\begin{array}{l}0,50 \\
0,59 \\
0,67\end{array}$ & $\begin{array}{l}0,47 \\
0,56 \\
0,65\end{array}$ & $\begin{array}{l}0,43 \\
0,53 \\
0,64\end{array}$ & $\begin{array}{l}0,42 \\
0,52 \\
0,63\end{array}$ & $\begin{array}{l}0,40 \\
0,51 \\
0,62\end{array}$ & 15 \\
\hline $\begin{array}{c}0,1 \% \\
1 \% \\
5 \%\end{array}$ & 20 & $\begin{array}{l}0,66 \\
0,73 \\
0,80\end{array}$ & $\begin{array}{l}0,62 \\
0,69 \\
0,78\end{array}$ & $\begin{array}{l}0,60 \\
0,68 \\
0,77\end{array}$ & $\begin{array}{l}0,58 \\
0,66 \\
0,76\end{array}$ & $\begin{array}{l}0,56 \\
0,66 \\
0,75\end{array}$ & $\begin{array}{l}0,56 \\
0,65 \\
0,75\end{array}$ & $\begin{array}{l}0,53 \\
0,64 \\
0,73\end{array}$ & $\begin{array}{l}0,51 \\
0,63 \\
0,72\end{array}$ & $\begin{array}{l}0,48 \\
0,61 \\
0,70\end{array}$ & $\begin{array}{l}0,44 \\
0,58 \\
0,68\end{array}$ & $\begin{array}{l}0,42 \\
0,54 \\
0,65\end{array}$ & $\begin{array}{l}0,41 \\
0,53 \\
0,65\end{array}$ & $\begin{array}{l}0,40 \\
0,52 \\
0,64\end{array}$ & 20 \\
\hline $\mathbf{P}$ & $\uparrow_{\mathrm{nf} 2}$ & $\inf$ & 100 & 75 & 50 & 45 & 40 & 35 & 30 & 25 & 20 & 15 & 14 & 13 & nf1 \\
\hline
\end{tabular}


b

¡TRIBUIÇÕES DE FISHER

te)

\begin{tabular}{|c|c|c|c|c|c|c|c|c|c|c|c|c|c|c|}
\hline 1 & 14 & 15 & 20 & 25 & 30 & 35 & 40 & 45 & 50 & 75 & 100 & $\inf$ & nf2 $\downarrow$ & $P$ \\
\hline 3 & 784 & 786 & 789 & 790 & 792 & 793 & 794 & 795 & 796 & 797 & 798 & 798 & & $0,1 \%$ \\
\hline 3 & 78,4 & & & & & & & & & & & & 1 & $1 \%$ \\
\hline ,1 & 15 & 1. & 15,1 & 15,1 & 15,1 & 15,1 & 15,1 & 15,1 & 15,1 & 15,1 & 15,1 & & & \\
\hline 6 & 316 & 316 & 316 & 316 & 316 & 316 & 316 & 316 & 316 & 316 & 316 & 316 & & $0,1 \%$ \\
\hline 17 & 9,97 & 9,97 & 9,97 & 9,97 & 9,97 & 9,97 & 9,79 & 9,97 & 9,97 & 9,97 & & 9,97 & 2 & $1 \%$ \\
\hline 4 & 4,41 & 4,41 & 4,41 & 4,41 & 4,41 & 4,41 & 4,42 & 4,42 & 4,42 & 4,42 & 4,42 & 4,42 & & $5 \%$ \\
\hline ,3 & 11,3 & 11,3 & 11,2 & 11,2 & 11,2 & 11,2 & 11,2 & 11,2 & 11,2 & 11,2 & 1,12 & 11,1 & & $0,1 \%$ \\
\hline 19 & 5,19 & 5,19 & 5,17 & 5,16 & 5,15 & 5,14 & 5,13 & 5,13 & $\begin{array}{l}5,13 \\
0,00\end{array}$ & 5,12 & 5,12 & 5,11 & 3 & $1 \%$ \\
\hline 95 & 2,95 & 2,95 & 2,94 & 2,94 & 2,94 & 2,93 & 2,93 & 2,92 & 2,92 & 2,92 & 2,92 & 2,91 & & $5 \%$ \\
\hline 86 & 6,84 & 6,82 & 6,79 & 6,77 & 6,75 & 6,73 & 6,72 & 6,71 & 6,70 & 6,70 & 6,69 & 6,64 & & $0 ; 1 \%$ \\
\hline 78 & 3,77 & 3,77 & 3,74 & 3,73 & 3,72 & 3,71 & 3,70 & 3,70 & 3,70 & 3,69 & 3,69 & & 4 & $1 \%$ \\
\hline 42 & 2,42 & 2,42 & 2,41 & 2,40 & 2,40 & 2,39 & 2,39 & 2,38 & 2,38 & 2,38 & 2,38 & 2,37 & & $5 \%$ \\
\hline 11 & 5,09 & 5,07 & 5,03 & 5,01 & $\begin{array}{l}4,99 \\
07\end{array}$ & 4,97 & 4,96 & 4,95 & 4,94 & 4,93 & 4,92 & 4,87 & & $0,1 \%$ \\
\hline $\begin{array}{l}13 \\
15\end{array}$ & $\begin{array}{l}3,1 \\
2,1\end{array}$ & $\begin{array}{l}3,1 \\
2,1\end{array}$ & $\begin{array}{l}3,09 \\
2,14\end{array}$ & 3,0 & $\begin{array}{l}3,0 \\
2,1\end{array}$ & 3,0 & 3,05 & $\begin{array}{l}3,0 \\
2\end{array}$ & 3, & & & & 5 & $1 \%$ \\
\hline 10) & 2,15 & 2,10 & 2,14 & 2,13 & 2,13 & 2,12 & 2,12 & 2,11 & 2,11 & 2,11 & 2,10 & 2, & & $5 \%$ \\
\hline 21 & $\begin{array}{l}4,19 \\
7\end{array}$ & 4,17 & $\begin{array}{l}4,13 \\
2\end{array}$ & 4,11 & 4,09 & 4,07 & 4,06 & 4,05 & 4,04 & 4,03 & 4,02 & $\begin{array}{l}3,97 \\
, 97\end{array}$ & & $0,1 \%$ \\
\hline 99 & $\begin{array}{l}2,76 \\
1,98\end{array}$ & $\begin{array}{l}2,75 \\
1,98\end{array}$ & $\begin{array}{l}2,71 \\
1,97\end{array}$ & $\begin{array}{l}2,70 \\
1,96\end{array}$ & $\begin{array}{l}2,69 \\
1,96\end{array}$ & & $\begin{array}{l}2,67 \\
1,95\end{array}$ & & $\begin{array}{l}2,65 \\
1,94\end{array}$ & $\begin{array}{l}2,64 \\
1,93\end{array}$ & $\begin{array}{l}2,64 \\
1,92\end{array}$ & $\begin{array}{l}2,62 \\
1,91\end{array}$ & 6 & $\begin{array}{l}1 \% \\
5 \%\end{array}$ \\
\hline 67 & $3,6 \tilde{5}$ & 3,63 & 3,59 & 3,57 & 3,5 & 3,53 & & & & & & & & \\
\hline & 2,52 & 2,51 & 2,47 & 2,46 & 2,45 & 2,4 & 2,4 & 2,4 & $\begin{array}{l}0,4 \\
2,4\end{array}$ & $\begin{array}{l}2,4 \\
2,4\end{array}$ & 2,4 & & 7 & 19 \\
\hline ,88 & 1,87 & 1,87 & 1,86 & 1,85 & 1,85 & 1,84 & 1,84 & 1,83 & 1,83 & 1,82 & 1,81 & 1,80 & & $5 \%$ \\
\hline 32 & 3,30 & 3,28 & 3,24 & 3,21 & 3,19 & 3,17 & 3,15 & 3,14 & 3,13 & 3,12 & 3,11 & 3,06 & & $0,1 \%$ \\
\hline $\begin{array}{l}.37 \\
80\end{array}$ & $\begin{array}{l}2,36 \\
70\end{array}$ & 2,35 & 2,31 & 2,30 & 2,2 & 2,28 & 2,2 & 2,2 & 2,2 & 2,2 & 2,2 & 2,21 & 8 & $1 \%$ \\
\hline 80 & 1,79 & 1,79 & 1,77 & 1,76 & 1,75 & 1,74 & 1,74 & 1,73 & 1,73 & 1,72 & 1,71 & 1,70 & & $5 \%$ \\
\hline ,07 & 3,05 & 3,03 & 2,99 & 2,96 & 2,93 & 3,91 & 2,89 & 2,88 & 2,87 & 2,85 & 2,84 & 2,79 & & $0,1 \%$ \\
\hline, 25 & $\begin{array}{l}2,24 \\
1,74\end{array}$ & $\begin{array}{l}2,23 \\
1,74\end{array}$ & $\begin{array}{l}2,19 \\
1,72\end{array}$ & $\begin{array}{l}2,18 \\
1,71\end{array}$ & $\begin{array}{l}2,17 \\
1,70\end{array}$ & $\begin{array}{l}2,16 \\
1,69\end{array}$ & $\begin{array}{l}2,15 \\
1,69\end{array}$ & $\begin{array}{l}2,14 \\
1,68\end{array}$ & $\begin{array}{l}2,13 \\
1,68\end{array}$ & $\begin{array}{l}2,12 \\
1,67\end{array}$ & & & 9 & $\begin{array}{l}1 \% \\
5 \%\end{array}$ \\
\hline 1,89 & 2,87 & 2,85 & 2,81 & 2.78 & 2,75 & $2,7:$ & 27 & & & & & & & \\
\hline & 2,1 & 2,1 & 2, & & & & & & & & & & 10 & 10 \\
\hline 70 & 1,69 & 1,69 & 1,67 & 1,66 & 1,65 & 1,64 & 1,64 & 1,63 & 1,63 & 1,62 & 1,61 & 1,59 & & $5 \%$ \\
\hline .73 & 2,71 & 2,69 & 2,6 & 2,6 & 2,5 & 2,5 & 2,5 & 2,5 & 2,5 & 2,5 & 2,5 & 2,45 & & $0,1 \%$ \\
\hline 9 & 2,08 & 2,07 & 2,0 & 2,0 & 1,99 & & 1,9 & & & & & & 11 & $1 \%$ \\
\hline 1,66 & 1,65 & 1,65 & 1,63 & 1,62 & 1,61 & 1,60 & 1,60 & 1,59 & 1,59 & 1,58 & 1,57 & 1,55 & & $5 \%$ \\
\hline 2,62 & 2,59 & 2,57 & 2,5 & 2, & 2,4 & & & & & & & 2,33 & & $0,1 \%$ \\
\hline $\begin{array}{l}2,0 \\
1,6\end{array}$ & $\begin{array}{l}2,02 \\
1,62\end{array}$ & 2,0 & $\begin{array}{l}1,90 \\
1,60\end{array}$ & & & & & & & & & 1,8 & 12 & $1 \%$ \\
\hline & 1,02 & 1,02 & 1,60 & 1,59 & 1,68 & 1,57 & 1,57 & 1,56 & 1,56 & 1,55 & 1,54 & 1,52 & & $0 \%$ \\
\hline 2,53 & 2,50 & 2,48 & 2,44 & 2,4 & 2,3 & 2,3 & 2,3 & 2,3 & & & 2,2 & & & $0,1 \%$ \\
\hline & $\begin{array}{l}1,97 \\
1,59\end{array}$ & $\begin{array}{l}1,36 \\
1,59\end{array}$ & $\begin{array}{l}1,91 \\
1,57\end{array}$ & & & & & & & & & & 13 & $\begin{array}{l}1 \% \\
50\end{array}$ \\
\hline & 1,00 & 1,08 & 1,06 & 1,00 & 1,00 & 1,04 & 1,04 & 1.03 & 1,33 & 1,02 & 1,61 & 1,49 & & \\
\hline & 2,4 & & 2.3 & & & & 29 & & & & & 2,16 & & $0,1 \%$ \\
\hline 1,58 & 1,57 & $\begin{array}{l}1,92 \\
1.52\end{array}$ & $\begin{array}{l}1,8 \\
1,5\end{array}$ & $\begin{array}{l}1,8 \\
1,5\end{array}$ & & & 1,81 & $\begin{array}{l}1,80 \\
1,50\end{array}$ & 1,79 & & & & 14 & $\begin{array}{l}1 \% \% \\
5 \%\end{array}$ \\
\hline 2,38 & 2,3 & & & & & & & & & 1,2, & 1,40 & 2,40 & & \\
\hline & 1,90 & & & & & 2,21 & 2,19 & 2,18 & 2,17 & 2,1 & 2,14 & $\begin{array}{l}2,08 \\
1,60\end{array}$ & 15 & $0,1 \%$ \\
\hline 1,56 & 1,55 & 1,55 & 1,53 & 1,51 & 1,50 & $\begin{array}{l}1,88 \\
1,49\end{array}$ & $\begin{array}{l}1,77 \\
1,49\end{array}$ & $\begin{array}{l}1,60 \\
1,48\end{array}$ & $\begin{array}{l}1,70 \\
1,48\end{array}$ & $\begin{array}{l}1,74 \\
1,47\end{array}$ & $\begin{array}{l}1,13 \\
1,46\end{array}$ & $\begin{array}{l}1,09 \\
1,44\end{array}$ & & $5 \%$ \\
\hline 2,17 & 2,1 & & 2, & 2 , & 2, & 1, & 1, & 1, & 1, & 1, & 1, & 1.8 & & \\
\hline 1,79 & 1,78 & 1,77 & 1,72 & 1,69 & 1,67 & & 1,64 & 1,6 & 1,6 & 1,6 & $1 ;$ & 1,56 & 20 & $1 \%$ \\
\hline 1,50 & 1,49 & 1,49 & 1,46 & 1,44 & 1,43 & 1,42 & 1,42 & 1,41 & 1,41 & 1,40 & 1,39 & 1,36 & & $5 \%$ \\
\hline 13 & 14 & 15 & 20 & 25 & 30 & 35 & 40 & 45 & 50 & 75 & 100 & inf & nf2 & $\mathbf{P}$ \\
\hline
\end{tabular}


T Á B U

LIMITES UNILATERAIS D

\begin{tabular}{|c|c|c|c|c|c|c|c|c|c|c|c|c|c|c|}
\hline $\mathrm{P}$ & $\downarrow^{n f 2}$ & 12 & 11 & 10 & 9 & 8 & 7 & 6 & 5 & 4 & 3 & 2 & 1 & \\
\hline $\begin{array}{c}0,1 \% \\
1 \% \\
5 \%\end{array}$ & 20 & $\begin{array}{l}0,40 \\
0,51 \\
0,63\end{array}$ & $\begin{array}{l}0,38 \\
0,50 \\
0,61\end{array}$ & $\begin{array}{l}0,36 \\
0,47 \\
0,60\end{array}$ & $\begin{array}{l}0,33 \\
0,46 \\
0,58\end{array}$ & $\begin{array}{l}0,31 \\
0,43 \\
0,56\end{array}$ & $\begin{array}{l}0,28 \\
0,40 \\
0,54\end{array}$ & $\begin{array}{l}0,24 \\
0,37 \\
0,51\end{array}$ & $\begin{array}{l}0,20 \\
0,32 \\
0,47\end{array}$ & $\begin{array}{l}0,15 \\
0,27 \\
0,41\end{array}$ & $\begin{array}{l}0,09 \\
0,19 \\
0,34\end{array}$ & $\begin{array}{l}0,03 \\
0,19 \\
0,23\end{array}$ & $\begin{array}{l}0,001 \\
0,013 \\
0,066\end{array}$ & \\
\hline $\begin{array}{c}0,1 \% \\
1 \% \\
5 \%\end{array}$ & 25 & $\begin{array}{l}0,40 \\
0,52 \\
0,63\end{array}$ & $\begin{array}{l}0,38 \\
0,50 \\
0,62\end{array}$ & $\begin{array}{l}0,36 \\
0,48 \\
0,60\end{array}$ & $\begin{array}{l}0,34 \\
0,46 \\
0,58\end{array}$ & $\begin{array}{l}0,31 \\
0,43 \\
0,57\end{array}$ & $\begin{array}{l}0,28 \\
0,41 \\
0,54\end{array}$ & $\begin{array}{l}0,24 \\
0,37 \\
0,51\end{array}$ & $\begin{array}{l}0,20 \\
0,32 \\
0,47\end{array}$ & $\begin{array}{l}0,15 \\
0,27 \\
0,42\end{array}$ & $\begin{array}{l}0,09 \\
0,19 \\
0,34\end{array}$ & $\begin{array}{l}0,03 \\
0,10 \\
0,23\end{array}$ & $\begin{array}{l}0,001 \\
0,013 \\
0,066\end{array}$ & 25 \\
\hline $\begin{array}{c}0,1 \% \\
1 \% \\
5 \%\end{array}$ & 30 & $\begin{array}{l}0,40 \\
0,52 \\
0,63\end{array}$ & $\begin{array}{l}0,39 \\
0,50 \\
0,62\end{array}$ & $\begin{array}{l}0,36 \\
0,48 \\
0,61\end{array}$ & $\begin{array}{l}0,34 \\
0,46 \\
0,59\end{array}$ & $\begin{array}{l}0,31 \\
0,44 \\
0,57\end{array}$ & $\begin{array}{l}0,28 \\
0,41 \\
0,54\end{array}$ & $\begin{array}{l}0,24 \\
0,37 \\
0,51\end{array}$ & $\begin{array}{l}0,20 \\
0,33 \\
0,47\end{array}$ & $\begin{array}{l}0,15 \\
0,27 \\
0,42\end{array}$ & $\begin{array}{l}0,09 \\
0,19 \\
0,34\end{array}$ & $\begin{array}{l}0,03 \\
0,10 \\
0,23\end{array}$ & $\begin{array}{l}0,001 \\
0,013 \\
0,066\end{array}$ & 30 \\
\hline $\begin{array}{c}0,1 \% \\
1 \% \\
5 \%\end{array}$ & 35 & $\begin{array}{l}0,41 \\
0,52 \\
0,64\end{array}$ & $\begin{array}{l}0,39 \\
0,51 \\
0,63\end{array}$ & $\begin{array}{l}0,37 \\
0,49 \\
0,61\end{array}$ & $\begin{array}{l}0,34 \\
0,46 \\
0,59\end{array}$ & $\begin{array}{l}0,32 \\
0,44 \\
0,57\end{array}$ & $\begin{array}{l}0,28 \\
0,41 \\
0,54\end{array}$ & $\begin{array}{l}0,25 \\
0,37 \\
0,51\end{array}$ & $\begin{array}{l}0,20 \\
0,33 \\
0,47\end{array}$ & $\begin{array}{l}0,15 \\
0,27 \\
0,42\end{array}$ & $\begin{array}{l}0,09 \\
0,19 \\
0,34\end{array}$ & $\begin{array}{l}0,03 \\
0,10 \\
0,23\end{array}$ & $\begin{array}{l}0,001 \\
0,013 \\
0,066\end{array}$ & 35 \\
\hline $\begin{array}{c}0.1 \% \\
1 \% \\
5 \%\end{array}$ & 40 & $\begin{array}{l}0,41 \\
0,53 \\
0,64\end{array}$ & $\begin{array}{l}0,39 \\
0,51 \\
0,63\end{array}$ & $\begin{array}{l}0,37 \\
0,49 \\
0,61\end{array}$ & $\begin{array}{l}0,35 \\
0,47 \\
0,59\end{array}$ & $\begin{array}{l}0,32 \\
0,44 \\
0,57\end{array}$ & $\begin{array}{l}0,28 \\
0,41 \\
0,54\end{array}$ & $\begin{array}{l}0,25 \\
0,37 \\
0,51\end{array}$ & $\begin{array}{l}0,20 \\
0,33 \\
0,47\end{array}$ & $\begin{array}{l}0,15 \\
0,27 \\
0,42\end{array}$ & $\begin{array}{l}0,09 \\
0,19 \\
0,34\end{array}$ & $\begin{array}{l}0,03 \\
0,10 \\
0,23\end{array}$ & $\begin{array}{l}0,001 \\
0,013 \\
0,066\end{array}$ & 40 \\
\hline $\begin{array}{c}0,1 \% \\
1 \% \\
5 \%\end{array}$ & 45 & $\begin{array}{l}0,41 \\
0,53 \\
0,64\end{array}$ & $\begin{array}{l}0,39 \\
0,51 \\
0,63\end{array}$ & $\begin{array}{l}0,37 \\
0,49 \\
0,61\end{array}$ & $\begin{array}{l}0,35 \\
0,47 \\
0,60\end{array}$ & $\begin{array}{l}0,32 \\
0,44 \\
0,58\end{array}$ & $\begin{array}{l}0,29 \\
0,41 \\
0,55\end{array}$ & $\begin{array}{l}0,25 \\
0,38 \\
0,52\end{array}$ & $\begin{array}{l}0,20 \\
0,33 \\
0,47\end{array}$ & $\begin{array}{l}0,15 \\
0,27 \\
0,42\end{array}$ & $\begin{array}{l}0,09 \\
0,20 \\
0,34\end{array}$ & $\begin{array}{l}0,03 \\
0,10 \\
0,23\end{array}$ & $\begin{array}{l}0,001 \\
0,013 \\
0,066\end{array}$ & 45 \\
\hline $\begin{array}{c}0,1 \% \\
1 \% \\
5 \%\end{array}$ & 50 & $\begin{array}{l}0,41 \\
0,53 \\
0,64\end{array}$ & $\begin{array}{l}0,40 \\
0,51 \\
0,63\end{array}$ & $\begin{array}{l}0,37 \\
0,49 \\
0,61\end{array}$ & $\begin{array}{l}0,35 \\
0,47 \\
0,60\end{array}$ & $\begin{array}{l}0.32 \\
0,44 \\
0,58\end{array}$ & $\begin{array}{l}0,29 \\
0,41 \\
0,55\end{array}$ & $\begin{array}{l}0,25 \\
0,38 \\
0,52\end{array}$ & $\begin{array}{l}\mathbf{0 , 2 0} \\
0,33 \\
\mathbf{0 , 4 7}\end{array}$ & $\begin{array}{l}0,15 \\
0,27 \\
0,42\end{array}$ & $\begin{array}{l}0,09 \\
0,20 \\
0,34\end{array}$ & $\begin{array}{l}0,03 \\
0,10 \\
0,23\end{array}$ & $\begin{array}{l}0,001 \\
0,013 \\
0,066\end{array}$ & 50 \\
\hline $\begin{array}{c}0.1 \% \\
1 \% \\
5 \%\end{array}$ & 75 & $\begin{array}{l}0,42 \\
0,53 \\
0,65\end{array}$ & $\begin{array}{l}0,40 \\
0,52 \\
0,63\end{array}$ & $\begin{array}{l}0,37 \\
0,50 \\
0,62\end{array}$ & $\begin{array}{l}0,35 \\
0,47 \\
0,60\end{array}$ & $\begin{array}{l}0,32 \\
0,45 \\
0,58\end{array}$ & $\begin{array}{l}0,29 \\
0,42 \\
0,55\end{array}$ & $\begin{array}{l}0,25 \\
0,38 \\
0,52\end{array}$ & $\begin{array}{l}0,20 \\
0,33 \\
0,47\end{array}$ & $\begin{array}{l}0,15 \\
0,27 \\
0,42\end{array}$ & $\begin{array}{l}0,09 \\
0,20 \\
0,34\end{array}$ & $\begin{array}{l}0,03 \\
0,10 \\
0,23\end{array}$ & $\begin{array}{l}0,001 \\
0,013 \\
0,066\end{array}$ & 75 \\
\hline $\begin{array}{c}0,1 \% \\
1 \% \\
5 \%\end{array}$ & 100 & $\begin{array}{l}0,42 \\
0,54 \\
0,65\end{array}$ & $\begin{array}{l}0,40 \\
0,52 \\
0,64\end{array}$ & $\begin{array}{l}0,38 \\
0,50 \\
0,62\end{array}$ & $\begin{array}{l}0,35 \\
0,47 \\
0,60\end{array}$ & $\begin{array}{l}0,32 \\
0,45 \\
0,58\end{array}$ & $\begin{array}{l}0,29 \\
0,42 \\
0,55\end{array}$ & $\begin{array}{l}0,25 \\
0,38 \\
0,52\end{array}$ & $\begin{array}{l}0,20 \\
0,33 \\
0,48\end{array}$ & $\begin{array}{l}0,15 \\
0,27 \\
0,42\end{array}$ & $\begin{array}{l}0,09 \\
0,20 \\
0,34\end{array}$ & $\begin{array}{l}0,03 \\
0,10 \\
0,23\end{array}$ & $\begin{array}{l}0,001 \\
0,013 \\
0,066\end{array}$ & 100 \\
\hline $\begin{array}{c}0,1 \% \\
1 \% \\
5 \%\end{array}$ & 500 & $\begin{array}{l}0,43 \\
0,55 \\
0,66\end{array}$ & $\begin{array}{l}0,41 \\
0,53 \\
0,65\end{array}$ & $\begin{array}{l}0,38 \\
0,51 \\
0,63\end{array}$ & $\begin{array}{l}0,36 \\
0,48 \\
0,61\end{array}$ & $\begin{array}{l}0,33 \\
0,45 \\
0,59\end{array}$ & $\begin{array}{l}0,29 \\
0,42 \\
0,56\end{array}$ & $\begin{array}{l}0,25 \\
0,28 \\
0,52\end{array}$ & $\begin{array}{l}0,21 \\
0,33 \\
0,48\end{array}$ & $\begin{array}{l}0,15 \\
0,27 \\
0,42\end{array}$ & $\begin{array}{l}0,09 \\
0,20 \\
0,34\end{array}$ & $\begin{array}{l}0,03 \\
0,10 \\
0,23\end{array}$ & $\begin{array}{l}0,001 \\
0,013 \\
0,066\end{array}$ & 500 \\
\hline $\begin{array}{c}0,1 \% \\
1 \% \\
5 \%\end{array}$ & $\inf$ & $\begin{array}{l}0,43 \\
0,55 \\
0,66\end{array}$ & $\begin{array}{l}0,41 \\
0,53 \\
0,65\end{array}$ & $\begin{array}{l}0,38 \\
0,51 \\
0,63\end{array}$ & $\begin{array}{l}0,36 \\
0,48 \\
0,61\end{array}$ & $\begin{array}{l}0,33 \\
0,45 \\
0,59\end{array}$ & $\begin{array}{l}0,29 \\
0,42 \\
0,56\end{array}$ & $\begin{array}{l}0,25 \\
0,38 \\
0,52\end{array}$ & $\begin{array}{l}0,21 \\
0,33 \\
0,48\end{array}$ & $\begin{array}{l}0,15 \\
0,27 \\
0,42\end{array}$ & $\begin{array}{l}0,09 \\
0,20 \\
0,34\end{array}$ & $\begin{array}{l}0,03 \\
0,10 \\
0,23\end{array}$ & $\begin{array}{l}0,001 \\
0,013 \\
0,066\end{array}$ & $\inf$ \\
\hline $\mathbf{P}$ & $\uparrow_{n f 2}$ & 12 & 11 & 10 & 9 & 8 & 7 & 6 & 5 & 4 & 3 & 2 & 1 & $\overleftarrow{\text { nf } 1}$ \\
\hline
\end{tabular}




\section{I c}

\section{DISTRIBUIÇÕES DE FISHER}

teste)

\begin{tabular}{|c|c|c|c|c|c|c|c|c|c|c|c|c|c|c|}
\hline$\stackrel{\mathrm{nf} 1}{\longrightarrow}$ & 1 & 2 & 3 & 4 & 5 & 6 & 7 & 8 & 9 & 10 & 11 & 12 & nf2 & $\Gamma^{\prime}$ \\
\hline 20 & $\begin{array}{l}3,84 \\
2,85 \\
2,09\end{array}$ & $\begin{array}{l}3,15 \\
2,42 \\
1,87\end{array}$ & $\begin{array}{l}2,85 \\
2,22 \\
1,76\end{array}$ & $\begin{array}{l}2,66 \\
2,10 \\
1,69\end{array}$ & $\begin{array}{l}2,54 \\
2,02 \\
1,64\end{array}$ & $\begin{array}{l}2,45 \\
1,97 \\
1,61\end{array}$ & $\begin{array}{l}2,38 \\
1,93 \\
1,58\end{array}$ & $\begin{array}{l}2,33 \\
1,89 \\
1,57\end{array}$ & $\begin{array}{l}2,29 \\
1,86 \\
1,55\end{array}$ & $\begin{array}{l}2,25 \\
1,83 \\
1,53\end{array}$ & $\begin{array}{l}2,22 \\
1,81 \\
1,52\end{array}$ & $\begin{array}{l}2,20 \\
1,80 \\
1,51\end{array}$ & 20 & $\begin{array}{c}0,1 \% \\
1 \% \\
5 \%\end{array}$ \\
\hline 25 & $\begin{array}{l}3,73 \\
2,79 \\
2,06\end{array}$ & $\begin{array}{l}3,04 \\
2,36 \\
1,84\end{array}$ & $\begin{array}{l}2,74 \\
2,16 \\
1,73\end{array}$ & $\begin{array}{l}2,55 \\
2,04 \\
1,66\end{array}$ & $\begin{array}{l}2,43 \\
1,96 \\
1,61\end{array}$ & $\begin{array}{l}2,34 \\
1,90 \\
1,58\end{array}$ & $\begin{array}{l}2,27 \\
1,86 \\
1,55\end{array}$ & $\begin{array}{l}2,22 \\
1,82 \\
1,53\end{array}$ & $\begin{array}{l}2,18 \\
1,79 \\
1,51\end{array}$ & $\begin{array}{l}2,14 \\
1,76 \\
1,49\end{array}$ & $\begin{array}{l}2,11 \\
1,74 \\
1,48\end{array}$ & $\begin{array}{l}2,08 \\
1,73 \\
1,47\end{array}$ & 25 & $\begin{array}{l}0,1 \% \\
1 \% \\
5 \%\end{array}$ \\
\hline 30 & $\begin{array}{l}3,65 \\
2,75 \\
2,04\end{array}$ & $\begin{array}{l}2,96 \\
2,32 \\
1,82\end{array}$ & $\begin{array}{l}2,66 \\
2,12 \\
1,71\end{array}$ & $\begin{array}{l}2,47 \\
2,00 \\
1,64\end{array}$ & $\begin{array}{l}2,35 \\
1,92 \\
1,59\end{array}$ & $\begin{array}{l}2,26 \\
1,80 \\
1,56\end{array}$ & $\begin{array}{l}2,19 \\
1,82 \\
1,53\end{array}$ & $\begin{array}{l}2,14 \\
1,78 \\
151\end{array}$ & $\begin{array}{l}2,10 \\
2,74 \\
1,49\end{array}$ & $\begin{array}{l}2,06 \\
1,71 \\
1,47\end{array}$ & $\begin{array}{l}2,03 \\
1,69 \\
1,46\end{array}$ & $\begin{array}{l}2,00 \\
1,68 \\
1,45\end{array}$ & 30 & $\begin{array}{l}0,1 \% \\
1 \% \\
5 \%\end{array}$ \\
\hline 35 & $\begin{array}{l}3,59 \\
2,73 \\
2,03\end{array}$ & $\begin{array}{l}2,90 \\
2,30 \\
1,81\end{array}$ & $\begin{array}{l}2,60 \\
2,10 \\
1,70\end{array}$ & $\begin{array}{l}2,41 \\
1,98 \\
1,63\end{array}$ & $\begin{array}{l}2,29 \\
1,90 \\
1,58\end{array}$ & $\begin{array}{l}2,20 \\
1,83 \\
1,54\end{array}$ & $\begin{array}{l}2,13 \\
1,79 \\
1,51\end{array}$ & $\begin{array}{l}2,08 \\
1,75 \\
1,49\end{array}$ & $\begin{array}{l}2,04 \\
1,71 \\
1,47\end{array}$ & $\begin{array}{l}2,00 \\
1,68 \\
1,45\end{array}$ & $\begin{array}{l}1,97 \\
1,66 \\
1,44\end{array}$ & $\begin{array}{l}1,94 \\
1,65 \\
1,43\end{array}$ & 35 & $\begin{array}{c}0,1 \% \\
1 \% \\
5 \%\end{array}$ \\
\hline 40 & $\begin{array}{l}3,56 \\
2,71 \\
2,02\end{array}$ & $\begin{array}{l}2,87 \\
2,28 \\
1,80\end{array}$ & $\begin{array}{l}2,57 \\
2,08 \\
1,69\end{array}$ & $\begin{array}{l}2,38 \\
1,96 \\
1,62\end{array}$ & $\begin{array}{l}2,26 \\
1,88 \\
1,57\end{array}$ & $\begin{array}{l}2,17 \\
1,81 \\
1,53\end{array}$ & $\begin{array}{l}2,10 \\
1,77 \\
1,50\end{array}$ & $\begin{array}{l}2,05 \\
1,73 \\
1,47\end{array}$ & $\begin{array}{l}2,01 \\
1,69 \\
1,45\end{array}$ & $\begin{array}{l}1,97 \\
1,66 \\
1,43\end{array}$ & $\begin{array}{l}1,94 \\
1,64 \\
1,42\end{array}$ & $\begin{array}{l}1,91 \\
1,63 \\
1,40\end{array}$ & 40 & $\begin{array}{c}0.1 \% \\
1 \% \\
5 \%\end{array}$ \\
\hline 45 & $\begin{array}{l}3,51 \\
2,69 \\
2,01\end{array}$ & $\begin{array}{l}2,84 \\
2,26 \\
1,79\end{array}$ & $\begin{array}{l}2,54 \\
2,06 \\
1,68\end{array}$ & $\begin{array}{l}2,35 \\
1,94 \\
1,61\end{array}$ & $\begin{array}{l}2,23 \\
1,86 \\
1,56\end{array}$ & $\begin{array}{l}2,14 \\
1,79 \\
1,52\end{array}$ & $\begin{array}{l}2,07 \\
1,75 \\
1,49\end{array}$ & $\begin{array}{l}2,02 \\
1,71 \\
1,46\end{array}$ & $\begin{array}{l}1,98 \\
1,67 \\
1,44\end{array}$ & $\begin{array}{l}1,94 \\
1,64 \\
1,42\end{array}$ & $\begin{array}{l}1,91 \\
1,62 \\
1,41\end{array}$ & $\begin{array}{l}1,88 \\
1,61 \\
1,39\end{array}$ & 45 & $\begin{array}{l}0,1 \% \\
1 \% \\
5 \%\end{array}$ \\
\hline 50 & $\begin{array}{l}3,49 \\
2,68 \\
2,00\end{array}$ & $\begin{array}{l}2,82 \\
2,25 \\
1,78\end{array}$ & $\begin{array}{l}2,52 \\
2,05 \\
1,67\end{array}$ & $\begin{array}{l}2,33 \\
1,93 \\
1,60\end{array}$ & $\begin{array}{l}2,21 \\
1,85 \\
1,55\end{array}$ & $\begin{array}{l}2,12 \\
1,78 \\
1,51\end{array}$ & $\begin{array}{l}2,05 \\
1,74 \\
1,48\end{array}$ & $\begin{array}{l}2,00 \\
1,70 \\
1,45\end{array}$ & $\begin{array}{l}1,96 \\
1,66 \\
1,43\end{array}$ & $\begin{array}{l}1,92 \\
1,63 \\
1,41\end{array}$ & $\begin{array}{l}1,89 \\
1,61 \\
1,40\end{array}$ & $\begin{array}{l}1,86 \\
1,60 \\
1,38\end{array}$ & 50 & $\begin{array}{c}0,1 \% \\
1 \% \\
5 \%\end{array}$ \\
\hline 75 & $\begin{array}{l}3,43 \\
2,65 \\
1,59\end{array}$ & $\begin{array}{l}2,76 \\
2,22 \\
1,77\end{array}$ & $\begin{array}{l}2,46 \\
2,02 \\
1,65\end{array}$ & $\begin{array}{l}2,27 \\
1,90 \\
1,58\end{array}$ & $\begin{array}{l}2,15 \\
1,82 \\
1,53\end{array}$ & $\begin{array}{l}2,06 \\
1,75 \\
1,49\end{array}$ & $\begin{array}{l}1,99 \\
1,71 \\
1,46\end{array}$ & $\begin{array}{l}1,9.1 \\
1,67 \\
1,43\end{array}$ & $\begin{array}{l}1,90 \\
1,63 \\
1,41\end{array}$ & $\begin{array}{l}1,86 \\
1,60 \\
1,39\end{array}$ & $\begin{array}{l}1,83 \\
1,58 \\
1,38\end{array}$ & $\begin{array}{l}1,80 \\
1,57 \\
1,36\end{array}$ & 75 & $\begin{array}{c}0,1 \% \\
1 \% \\
5 \%\end{array}$ \\
\hline 100 & $\begin{array}{l}3,39 \\
2,64 \\
1,98\end{array}$ & $\begin{array}{l}2,72 \\
2,21 \\
1,76\end{array}$ & $\begin{array}{l}2,42 \\
2,00 \\
1,64\end{array}$ & $\begin{array}{l}2,23 \\
1,88 \\
1,57\end{array}$ & $\begin{array}{l}2,11 \\
1,80 \\
1,52\end{array}$ & $\begin{array}{l}2,02 \\
1,73 \\
1,48\end{array}$ & $\begin{array}{l}1,95 \\
1,69 \\
1,45\end{array}$ & $\begin{array}{l}1,90 \\
1,65 \\
1,42\end{array}$ & $\begin{array}{l}1,86 \\
1,61 \\
1,40\end{array}$ & $\begin{array}{l}1,82 \\
1,58 \\
1,38\end{array}$ & $\begin{array}{l}1,79 \\
1,56 \\
1,37\end{array}$ & $\begin{array}{l}1,76 \\
1,55 \\
1,35\end{array}$ & 100 & $\begin{array}{c}0,1 \% \\
1 \% \\
5 \%\end{array}$ \\
\hline 500 & $\begin{array}{l}3,33 \\
2,60 \\
1,97\end{array}$ & $\begin{array}{l}2,66 \\
2,17 \\
1,74\end{array}$ & $\begin{array}{l}2,36 \\
1,96 \\
1,62\end{array}$ & $\begin{array}{l}2,17 \\
1,84 \\
1,55\end{array}$ & $\begin{array}{l}2,05 \\
1,70 \\
1,50\end{array}$ & $\begin{array}{l}1,96 \\
1,69 \\
1,46\end{array}$ & $\begin{array}{l}1,89 \\
1,65 \\
1,43\end{array}$ & $\begin{array}{l}1,84 \\
1,61 \\
1,40\end{array}$ & $\begin{array}{l}1,80 \\
1,57 \\
1,38\end{array}$ & $\begin{array}{l}1,76 \\
1,54 \\
1,36\end{array}$ & $\begin{array}{l}1,73 \\
1,52 \\
1,35\end{array}$ & $\begin{array}{l}1,70 \\
1,50 \\
1,34\end{array}$ & 500 & $\begin{array}{l}0,1 \% \\
1 \% \\
5 \%\end{array}$ \\
\hline inf. & $\begin{array}{l}3,29 \\
2,58 \\
1,96\end{array}$ & $\begin{array}{l}2,63 \\
2,15 \\
1,73\end{array}$ & $\begin{array}{l}2,33 \\
1,95 \\
1,61\end{array}$ & $\begin{array}{l}2,15 \\
1,82 \\
1,54\end{array}$ & $\begin{array}{l}2,02 \\
1,74 \\
1,49\end{array}$ & $\begin{array}{l}1,93 \\
1,67 \\
1,45\end{array}$ & $\begin{array}{l}1,86 \\
1,62 \\
1,42\end{array}$ & $\begin{array}{l}1,81 \\
1,58 \\
1,39\end{array}$ & $\begin{array}{l}1,77 \\
1,55 \\
1,37\end{array}$ & $\begin{array}{l}1,72 \\
1,52 \\
1,35\end{array}$ & $\begin{array}{l}1,69 \\
1,50 \\
1,34\end{array}$ & $\begin{array}{l}1,66 \\
1,48 \\
1,33\end{array}$ & inf. & $\begin{array}{c}0,1 \% \\
1 \% \\
5 \%\end{array}$ \\
\hline $\overrightarrow{\mathrm{nfl}}$ & 1 & 2 & 3 & 4 & 5 & 6 & 7 & 8 & 9 & 10 & 11 & 12 & nf2 & l' \\
\hline
\end{tabular}


T Á B U A

LIMITES UNILATERAIS DAS

(Teta-

\begin{tabular}{|c|c|c|c|c|c|c|c|c|c|c|c|c|c|c|c|}
\hline$P$ & $\left.\right|^{\mathrm{nf} 2} \downarrow$ & $\inf$ & 100 & 75 & 50 & 45 & 40 & 35 & 30 & 25 & 20 & 15 & 1.4 & 13 & $\stackrel{n f 1}{\leftarrow}$ \\
\hline $\begin{array}{r}0.1 \% \\
1 \% \\
5 \%\end{array}$ & 20 & $\begin{array}{l}0,66 \\
0,73 \\
0,80\end{array}$ & $\begin{array}{l}0,62 \\
0,69 \\
0,78\end{array}$ & $\begin{array}{l}0,60 \\
0,68 \\
0,77\end{array}$ & $\begin{array}{l}0,58 \\
0,66 \\
0,76\end{array}$ & $\begin{array}{l}0,56 \\
0,66 \\
0,75\end{array}$ & $\begin{array}{l}0,56 \\
0,65 \\
0,75\end{array}$ & $\begin{array}{l}0,53 \\
0,64 \\
0,73\end{array}$ & $\begin{array}{l}0,51 \\
0,63 \\
0,72\end{array}$ & $\begin{array}{l}0,48 \\
0,61 \\
0,70\end{array}$ & $\begin{array}{l}0,44 \\
0,58 \\
0,68\end{array}$ & $\begin{array}{l}0,42 \\
0,54 \\
0,65\end{array}$ & $\begin{array}{l}0,41 \\
0,53 \\
0,65\end{array}$ & $\begin{array}{l}0,40 \\
0,52 \\
0,64\end{array}$ & 20 \\
\hline $\begin{array}{r}0.1 \% \\
1 \% \\
5 \%\end{array}$ & 25 & $\begin{array}{l}0,69 \\
0,75 \\
0,81\end{array}$ & $\begin{array}{l}0,64 \\
0,70 \\
0,79\end{array}$ & $\begin{array}{l}0,62 \\
0,69 \\
0,78\end{array}$ & $\begin{array}{l}0,60 \\
0,68 \\
0,77\end{array}$ & $\begin{array}{l}0,59 \\
0,67 \\
0,76\end{array}$ & $\begin{array}{l}0,58 \\
0,66 \\
0,76\end{array}$ & $\begin{array}{l}0,57 \\
0,65 \\
0,7-4\end{array}$ & $\begin{array}{l}0,55 \\
0,64 \\
0,73\end{array}$ & $\begin{array}{l}0,52 \\
0,62 \\
0,71\end{array}$ & $\begin{array}{l}0,49 \\
0,59 \\
0,69\end{array}$ & $\begin{array}{l}0,44 \\
0,55 \\
0,66\end{array}$ & $\begin{array}{l}0,43 \\
0,54 \\
0,65\end{array}$ & $\begin{array}{l}0,41 \\
0,53 \\
0,64\end{array}$ & 25 \\
\hline $\begin{array}{r}0,1 \% \\
1 \% \\
5 \%\end{array}$ & 30 & $\begin{array}{l}0,70 \\
0,76 \\
0,83\end{array}$ & $\begin{array}{l}0,65 \\
0,72 \\
0,79\end{array}$ & $\begin{array}{l}0,63 \\
0,71 \\
0,79\end{array}$ & $\begin{array}{l}0,61 \\
0,69 \\
0,78\end{array}$ & $\begin{array}{l}0,61 \\
0,68 \\
0,78\end{array}$ & $\begin{array}{l}0,59 \\
0,68 \\
0,76\end{array}$ & $\begin{array}{l}0, .88 \\
0,66 \\
0,75\end{array}$ & $\begin{array}{l}0,56 \\
0,65 \\
0.74\end{array}$ & $\begin{array}{l}0,53 \\
0,63 \\
0,72\end{array}$ & $\begin{array}{l}0,50 \\
0,60 \\
0.70\end{array}$ & $\begin{array}{l}0,45 \\
0,56 \\
0,67\end{array}$ & $\begin{array}{l}0,43 \\
0,55 \\
0.66\end{array}$ & $\begin{array}{l}0,+2 \\
0,53 \\
0,65\end{array}$ & 30 \\
\hline $\begin{array}{r}0.1 \% \\
1 \% \\
5 \%\end{array}$ & 35 & $\begin{array}{l}0,72 \\
0,77 \\
0,83\end{array}$ & $\begin{array}{l}0,67 \\
0,73 \\
0,80\end{array}$ & $\begin{array}{l}0,64 \\
0.72 \\
0.79\end{array}$ & $\begin{array}{l}0,63 \\
0,70 \\
0,78\end{array}$ & $\begin{array}{l}0,62 \\
0,69 \\
0.78\end{array}$ & $\begin{array}{l}0,60 \\
0,68 \\
0,77\end{array}$ & $\begin{array}{l}0,59 \\
0,67 \\
0.75\end{array}$ & $\begin{array}{l}0,56 \\
0,65 \\
0,74\end{array}$ & $\begin{array}{l}0,54 \\
0,63 \\
0,72\end{array}$ & $\begin{array}{l}0,50 \\
0,61 \\
0,70\end{array}$ & $\begin{array}{l}0,45 \\
0,56 \\
0,67\end{array}$ & $\begin{array}{l}0,44 \\
0.55 \\
0,60\end{array}$ & $\begin{array}{l}0,42 \\
0,54 \\
0,65\end{array}$ & 35 \\
\hline $\begin{array}{r}0.1 \% \\
1 \% \\
1 \% \%\end{array}$ & 40 & $\begin{array}{l}0,74 \\
0,79 \\
0,85\end{array}$ & $\begin{array}{l}0,68 \\
0,74 \\
0,81\end{array}$ & $\begin{array}{l}0,65 \\
0,73 \\
0,79\end{array}$ & $\begin{array}{l}0,63 \\
, 071 \\
0,78\end{array}$ & $\begin{array}{l}0,63 \\
0,70 \\
0,78\end{array}$ & $\begin{array}{l}0,61 \\
0,69 \\
0,77\end{array}$ & $\begin{array}{l}0,60 \\
0,68 \\
0,75\end{array}$ & $\begin{array}{l}0,57 \\
0,66 \\
0,74\end{array}$ & $\begin{array}{l}0,54 \\
0,64 \\
0.72\end{array}$ & $\begin{array}{l}0,51 \\
0,61 \\
0,70\end{array}$ & $\begin{array}{l}0,46 \\
0,56 \\
0,67\end{array}$ & $\begin{array}{l}0.44 \\
0,55 \\
0.66\end{array}$ & $\begin{array}{l}0,43 \\
0,54 \\
0,65\end{array}$ & 40 \\
\hline $\begin{array}{r}0.1 \% \\
1 \% \\
5 \%\end{array}$ & +5 & $\begin{array}{l}0,75 \\
0,80 \\
0,85\end{array}$ & $\begin{array}{l}0,68 \\
0,75 \\
0,81\end{array}$ & $\begin{array}{l}0,66 \\
0,74 \\
0,80\end{array}$ & $\begin{array}{l}0,64 \\
0,71 \\
0.79\end{array}$ & $\begin{array}{l}0.63 \\
0.71 \\
0.78\end{array}$ & $\begin{array}{l}0,61 \\
0,69 \\
0,78\end{array}$ & $\begin{array}{l}0.60 \\
0.68 \\
0.76\end{array}$ & $\begin{array}{l}0,57 \\
0,66 \\
0.75\end{array}$ & $\begin{array}{l}0,55 \\
0,64 \\
0,73\end{array}$ & $\begin{array}{l}0,51 \\
0,61 \\
0,71\end{array}$ & $\begin{array}{l}0,46 \\
0,57 \\
0,68\end{array}$ & $\begin{array}{l}0,44 \\
0,56 \\
0,67\end{array}$ & $\begin{array}{l}0,43 \\
0,54 \\
0,65\end{array}$ & 45 \\
\hline $\begin{array}{r}0.1 \% \\
1 \% \\
.5 \%\end{array}$ & 50 & $\begin{array}{l}0,76 \\
0,81 \\
0,86\end{array}$ & $\begin{array}{l}0,69 \\
0,75 \\
0,82\end{array}$ & $\begin{array}{l}0,67 \\
0,74 \\
0,80\end{array}$ & $\begin{array}{l}0,64 \\
0,72 \\
0,79\end{array}$ & $\begin{array}{l}0,63 \\
0,71 \\
0,78\end{array}$ & $\begin{array}{l}0,62 \\
0,70 \\
0,78\end{array}$ & $\begin{array}{l}0,61 \\
0,68 \\
0,76\end{array}$ & $\begin{array}{l}0,57 \\
0,67 \\
0,75\end{array}$ & $\begin{array}{l}0,55 \\
0,65 \\
0,73\end{array}$ & $\begin{array}{l}0,51 \\
0,62 \\
0,71\end{array}$ & $\begin{array}{l}0,46 \\
0,57 \\
0,68\end{array}$ & $\begin{array}{l}0,45 \\
0,56 \\
0,67\end{array}$ & $\begin{array}{l}0,43 \\
0,55 \\
0,65\end{array}$ & 50 \\
\hline $\begin{array}{r}0,1 \% \\
1 \% \\
5 \%\end{array}$ & $7 j$ & $\begin{array}{l}0,80 \\
0,84 \\
0,88\end{array}$ & $\begin{array}{l}0,71 \\
0,78 \\
0,84\end{array}$ & $\begin{array}{l}0,69 \\
0,76 \\
0,83\end{array}$ & $\begin{array}{l}0,66 \\
0,72 \\
0,80\end{array}$ & $\begin{array}{l}0,65 \\
0,72 \\
0,79\end{array}$ & $\begin{array}{l}0,63 \\
0,71 \\
0,79\end{array}$ & $\begin{array}{l}0,62 \\
0,69 \\
0.77\end{array}$ & $\begin{array}{l}0,59 \\
0,68 \\
0,76\end{array}$ & $\begin{array}{l}0.56 \\
0.65 \\
0.74\end{array}$ & $\begin{array}{l}0,52 \\
0,62 \\
0,71\end{array}$ & $\begin{array}{l}0,47 \\
0,57 \\
0,68\end{array}$ & $\begin{array}{l}0.45 \\
0,56 \\
0.67\end{array}$ & $\begin{array}{l}0,43 \\
0,55 \\
0,66\end{array}$ & 75 \\
\hline $\begin{array}{r}0,1 \% \\
1 \% \\
5 \%\end{array}$ & 100 & $\begin{array}{l}0,83 \\
0,87 \\
0,90\end{array}$ & $\begin{array}{l}0,78 \\
0,79 \\
0,85\end{array}$ & $\begin{array}{l}0,70 \\
0,77 \\
0,83\end{array}$ & $\begin{array}{l}0,67 \\
0,74 \\
0,81\end{array}$ & $\begin{array}{l}0,66 \\
0,73 \\
0,80\end{array}$ & $\begin{array}{l}0,64 \\
0,71 \\
0,79\end{array}$ & $\begin{array}{l}0.63 \\
0,70 \\
0.78\end{array}$ & $\begin{array}{l}0,59 \\
0,68 \\
0,76\end{array}$ & $\begin{array}{l}0,56 \\
0,66 \\
0,75\end{array}$ & $\begin{array}{l}0,52 \\
0,63 \\
0,72\end{array}$ & $\begin{array}{l}0,47 \\
0,58 \\
0,68\end{array}$ & $\begin{array}{l}0,45 \\
0,56 \\
0,68\end{array}$ & $\begin{array}{l}0,44 \\
0,55 \\
0,66\end{array}$ & 100 \\
\hline $\begin{array}{r}0.1 \% \\
1 \% \\
5 \%\end{array}$ & 500 & $\begin{array}{l}0,91 \\
0,93 \\
0,95\end{array}$ & $\begin{array}{l}0,72 \\
0,83 \\
0,88\end{array}$ & $\begin{array}{l}0,75 \\
0,81 \\
0,87\end{array}$ & $\begin{array}{l}0,71 \\
0,78 \\
0,84\end{array}$ & $\begin{array}{l}0,68 \\
0,75 \\
0,82\end{array}$ & $\begin{array}{l}0,66 \\
0,73 \\
0,81\end{array}$ & $\begin{array}{l}0,64 \\
0,71 \\
0,79\end{array}$ & $\begin{array}{l}0,60 \\
0,69 \\
0,77\end{array}$ & $\begin{array}{l}0,57 \\
0,67 \\
0,76\end{array}$ & $\begin{array}{l}0,53 \\
0,64 \\
0,73\end{array}$ & $\begin{array}{l}0,48 \\
0,59 \\
0,69\end{array}$ & $\begin{array}{l}0,46 \\
0,57 \\
0,68\end{array}$ & $\begin{array}{l}0,45 \\
0,56 \\
0,67\end{array}$ & 500 \\
\hline $\begin{array}{r}0,1 \% \\
1 \% \\
5 \%\end{array}$ & inf & $\begin{array}{l}1,00 \\
1,00 \\
1,00\end{array}$ & $\begin{array}{l}0,78 \\
0,8^{4} \\
0,88\end{array}$ & $\begin{array}{l}0,75 \\
0,81 \\
0,87\end{array}$ & $\begin{array}{l}0,71 \\
0,78 \\
0,84\end{array}$ & $\begin{array}{l}0,69 \\
0.76 \\
0.83\end{array}$ & $\begin{array}{l}0,67 \\
0,74 \\
0,82\end{array}$ & $\begin{array}{l}0,65 \\
0,72 \\
0,80\end{array}$ & $\begin{array}{l}0,61 \\
0,70 \\
0.78\end{array}$ & $\begin{array}{l}0,58 \\
0,68 \\
0,76\end{array}$ & $\begin{array}{l}0, \tilde{54} \\
0,64 \\
0,74\end{array}$ & $\begin{array}{l}0,48 \\
0,59 \\
0,69\end{array}$ & $\begin{array}{l}0,46 \\
0,58 \\
0,68\end{array}$ & $\begin{array}{l}0,45 \\
0,56 \\
0,67\end{array}$ & $\inf$ \\
\hline $\mathbf{P}$ & $\operatorname{lnf2}$ & $\inf$ & 100 & 75 & 50 & 45 & 40 & 35 & 30 & 25 & 20 & 15 & 14 & 1.3 & if 1 \\
\hline
\end{tabular}




\section{I d}

DISTRIBUIÇÕES DE FISHER

teste)

\begin{tabular}{|c|c|c|c|c|c|c|c|c|c|c|c|c|c|c|c|}
\hline$\stackrel{\text { nf } 1}{\longrightarrow}$ & 13 & 14 & 15 & 20 & 25 & 30 & 35 & 40 & 45 & 50 & 75 & 100 & inf & {$[\mathrm{nf} 2\rfloor$} & $\mathbf{P}$ \\
\hline 20 & $\begin{array}{l}2,17 \\
1,79 \\
1,50\end{array}$ & $\begin{array}{l}2,14 \\
1,78 \\
1,49\end{array}$ & $\begin{array}{l}2,12 \\
1,77 \\
1,49\end{array}$ & $\begin{array}{l}2,08 \\
1,72 \\
1,46\end{array}$ & $\begin{array}{l}2,04 \\
1,69 \\
1,44\end{array}$ & $\begin{array}{l}2,01 \\
1,67 \\
1,43\end{array}$ & $\begin{array}{l}1,99 \\
1,65 \\
1,42\end{array}$ & $\begin{array}{l}1,97 \\
1,64 \\
1,42\end{array}$ & $\begin{array}{l}1,96 \\
1,63 \\
1,41\end{array}$ & $\begin{array}{l}1,95 \\
1,62 \\
1,41\end{array}$ & $\begin{array}{l}1,93 \\
1,61 \\
1,40\end{array}$ & $\begin{array}{l}1,92 \\
1,60 \\
1,39\end{array}$ & $\begin{array}{l}1,86 \\
1,56 \\
1,36\end{array}$ & 20 & $\begin{array}{r}0.1 \% \\
1 \% \\
5 \%\end{array}$ \\
\hline 25 & $\begin{array}{l}2,05 \\
1,72 \\
1,46\end{array}$ & $\begin{array}{l}2,02 \\
1,71 \\
1,45\end{array}$ & $\begin{array}{l}2,00 \\
1,70 \\
1,45\end{array}$ & $\begin{array}{l}1,95 \\
1,65 \\
1,42\end{array}$ & $\begin{array}{l}1,91 \\
1,62 \\
1,40\end{array}$ & $\begin{array}{l}1,88 \\
1,60 \\
1,39\end{array}$ & $\begin{array}{l}1,86 \\
1,58 \\
1,38\end{array}$ & $\begin{array}{l}1,84 \\
1,57 \\
1,38\end{array}$ & $\begin{array}{l}1,83 \\
1,56 \\
1,37\end{array}$ & $\begin{array}{l}1,82 \\
1,55 \\
1,37\end{array}$ & $\begin{array}{l}1,79 \\
1,53 \\
1,35\end{array}$ & $\begin{array}{l}1,78 \\
1,52 \\
1,34\end{array}$ & $\begin{array}{l}1,72 \\
1,47 \\
1,31\end{array}$ & 25 & $\begin{array}{r}0,1 \% \\
1 \% \\
5 \%\end{array}$ \\
\hline 30 & $\begin{array}{l}1,97 \\
1,67 \\
1,44\end{array}$ & $\begin{array}{l}1,94 \\
1,66 \\
1,43\end{array}$ & $\begin{array}{l}1,92 \\
1,65 \\
1,42\end{array}$ & $\begin{array}{l}1,87 \\
1,60 \\
1,39\end{array}$ & $\begin{array}{l}1,83 \\
1,57 \\
1,37\end{array}$ & $\begin{array}{l}1,80 \\
1,55 \\
1,36\end{array}$ & $\begin{array}{l}1,78 \\
1,53 \\
1,35\end{array}$ & $\begin{array}{l}1,76 \\
1,52 \\
1,35\end{array}$ & $\begin{array}{l}1,75 \\
1,51 \\
1,34\end{array}$ & $\begin{array}{l}1,74 \\
1,50 \\
1,34\end{array}$ & $\begin{array}{l}1,70 \\
1,48 \\
1,32\end{array}$ & $\begin{array}{l}1,69 \\
1,47 \\
1,31\end{array}$ & $\begin{array}{l}1,63 \\
1,42 \\
1,27\end{array}$ & 30 & $\begin{array}{r}0,1 \% \\
1 \% \\
5 \%\end{array}$ \\
\hline 35 & $\begin{array}{l}1,91 \\
1,64 \\
1,42\end{array}$ & $\begin{array}{l}1,87 \\
1,63 \\
1,41\end{array}$ & $\begin{array}{l}1,85 \\
1,62 \\
1,40\end{array}$ & $\begin{array}{l}1,80 \\
1,57 \\
1,37\end{array}$ & $\begin{array}{l}1,76 \\
1,54 \\
1,35\end{array}$ & $\begin{array}{l}1,72 \\
1,51 \\
1,34\end{array}$ & $\begin{array}{l}1,69 \\
1,49 \\
1,33\end{array}$ & $\begin{array}{l}1,67 \\
1,48 \\
1,33\end{array}$ & $\begin{array}{l}1,66 \\
1,47 \\
1,32\end{array}$ & $\begin{array}{l}1,65 \\
1,46 \\
1,32\end{array}$ & $\begin{array}{l}1,61 \\
1,44 \\
1,30\end{array}$ & $\begin{array}{l}1,60 \\
1,43 \\
1,29\end{array}$ & $\begin{array}{l}1,53 \\
1,38 \\
1,25\end{array}$ & 35 & $\begin{array}{r}0,1 \% \\
1 \% \\
5 \%\end{array}$ \\
\hline 40 & $\begin{array}{l}1,88 \\
1,62 \\
1,39\end{array}$ & $\begin{array}{l}1,84 \\
1,61 \\
1,38\end{array}$ & $\begin{array}{l}1,82 \\
1,60 \\
1,37\end{array}$ & $\begin{array}{l}1,77 \\
1,54 \\
1,34\end{array}$ & $\begin{array}{l}1,73 \\
1,51 \\
1,32\end{array}$ & $\begin{array}{l}1,69 \\
1,48 \\
1,31\end{array}$ & $\begin{array}{l}1,66 \\
1,46 \\
1,30\end{array}$ & $\begin{array}{l}1,64 \\
1,45 \\
1,30\end{array}$ & $\begin{array}{l}1,63 \\
1,44 \\
1,29\end{array}$ & $\begin{array}{l}1,62 \\
1,43 \\
1,29\end{array}$ & $\begin{array}{l}1,58 \\
1,41 \\
1,27\end{array}$ & $\begin{array}{l}1,56 \\
1,40 \\
1,26\end{array}$ & $\begin{array}{l}1,49 \\
1,35 \\
1,22\end{array}$ & 40 & $\begin{array}{r}0,1 \% \\
1 \% \\
5 \%\end{array}$ \\
\hline 45 & $\begin{array}{l}1,84 \\
1,60 \\
1,38\end{array}$ & $\begin{array}{l}1,80 \\
1,59 \\
1,37\end{array}$ & $\begin{array}{l}1,78 \\
1,58 \\
1,36\end{array}$ & $\begin{array}{l}1,73 \\
1,52 \\
1,33\end{array}$ & $\begin{array}{l}1,69 \\
1,49 \\
1,31\end{array}$ & $\begin{array}{l}1,65 \\
1,46 \\
1,30\end{array}$ & $\begin{array}{l}1,62 \\
1,44 \\
1,29\end{array}$ & $\begin{array}{l}1,60 \\
1,42 \\
1,29\end{array}$ & $\begin{array}{l}1,59 \\
1,41 \\
1,28\end{array}$ & $\begin{array}{l}1,58 \\
1,40 \\
1,28\end{array}$ & $\begin{array}{l}1,54 \\
1,38 \\
1,26\end{array}$ & $\begin{array}{l}1,52 \\
1,37 \\
1,25\end{array}$ & $\begin{array}{l}1,45 \\
1,31 \\
1,21\end{array}$ & 45 & $\begin{array}{r}0,1 \% \\
1 \% \\
.5 \%\end{array}$ \\
\hline 50 & $\begin{array}{l}1,82 \\
1,59 \\
1,37\end{array}$ & $\begin{array}{l}1,78 \\
1,58 \\
1,36\end{array}$ & $\begin{array}{l}1,76 \\
1,57 \\
1,35\end{array}$ & $\begin{array}{l}1,71 \\
1,51 \\
1,32\end{array}$ & $\begin{array}{l}1,67 \\
1,48 \\
1,30\end{array}$ & $\begin{array}{l}1,63 \\
1,45 \\
1,29\end{array}$ & $\begin{array}{l}1,60 \\
1,43 \\
1,28\end{array}$ & $\begin{array}{l}1,58 \\
1,41 \\
1,28\end{array}$ & $\begin{array}{l}1,57 \\
1,40 \\
1,27\end{array}$ & $\begin{array}{l}1,56 \\
1,39 \\
1,27\end{array}$ & $\begin{array}{l}1,52 \\
1,37 \\
1,25\end{array}$ & $\begin{array}{l}1,50 \\
1,35 \\
1,24\end{array}$ & $\begin{array}{l}1,40 \\
1,28 \\
1,19\end{array}$ & 50 & $\begin{array}{r}0,1 \% \\
1 \% \\
5 \%\end{array}$ \\
\hline 75 & $\begin{array}{l}1,76 \\
1,56 \\
1,35\end{array}$ & $\begin{array}{l}1,73 \\
1,55 \\
1,34\end{array}$ & $\begin{array}{l}1,71 \\
1,54 \\
1,33\end{array}$ & $\begin{array}{l}1,66 \\
1,47 \\
1,30\end{array}$ & $\begin{array}{l}1,62 \\
1,44 \\
1,28\end{array}$ & $\begin{array}{l}1,58 \\
1,41 \\
1,27\end{array}$ & $\begin{array}{l}1,55 \\
1,39 \\
1,26\end{array}$ & $\begin{array}{l}1,53 \\
1,37 \\
1,26\end{array}$ & $\begin{array}{l}1,51 \\
1,36 \\
1,25\end{array}$ & $\begin{array}{l}1,49 \\
1,35 \\
1,24\end{array}$ & $\begin{array}{l}1,45 \\
1,32 \\
1,21\end{array}$ & $\begin{array}{l}1,43 \\
1,30 \\
1,20\end{array}$ & $\begin{array}{l}1,33 \\
1,24 \\
1,15\end{array}$ & 75 & $\begin{array}{r}0,1 \% \\
1 \% \\
5 \%\end{array}$ \\
\hline 100 & $\begin{array}{l}1,72 \\
1,54 \\
1,34\end{array}$ & $\begin{array}{l}1,69 \\
1,53 \\
1,33\end{array}$ & $\begin{array}{l}1,67 \\
1,52 \\
1,32\end{array}$ & $\begin{array}{l}1,62 \\
1,45 \\
1,29\end{array}$ & $\begin{array}{l}1,57 \\
1,42 \\
1,27\end{array}$ & $\begin{array}{l}1,53 \\
1,39 \\
1,26\end{array}$ & $\begin{array}{l}1,50 \\
1,37 \\
1,25\end{array}$ & $\begin{array}{l}1,48 \\
1,35 \\
1,24\end{array}$ & $\begin{array}{l}1,46 \\
1,34 \\
1,23\end{array}$ & $\begin{array}{l}1,44 \\
1,33 \\
1,22\end{array}$ & $\begin{array}{l}1,40 \\
1,29 \\
1,19\end{array}$ & $\begin{array}{l}1,38 \\
1,26 \\
1,18\end{array}$ & $\begin{array}{l}1,28 \\
1,20 \\
1,13\end{array}$ & 100 & $\begin{array}{r}0,1 \% \\
1 \% \\
5 \%\end{array}$ \\
\hline 500 & $\begin{array}{l}1,66 \\
1,48 \\
1,32\end{array}$ & $\begin{array}{l}1,63 \\
1,46 \\
1,31\end{array}$ & $\begin{array}{l}1,61 \\
1,45 \\
1,30\end{array}$ & $\begin{array}{l}1,52 \\
1,38 \\
1,26\end{array}$ & $\begin{array}{l}1,46 \\
1,34 \\
1,23\end{array}$ & $\begin{array}{l}1,42 \\
1,31 \\
1,21\end{array}$ & $\begin{array}{l}1,39 \\
1,29 \\
1,20\end{array}$ & $\begin{array}{l}1,37 \\
1,28 \\
1,19\end{array}$ & $\begin{array}{l}1,35 \\
1,27 \\
1,19\end{array}$ & $\begin{array}{l}1,33 \\
1,26 \\
1,18\end{array}$ & $\begin{array}{l}1,28 \\
1,21 \\
1,15\end{array}$ & $\begin{array}{l}1,26 \\
1,18 \\
1,13\end{array}$ & $\begin{array}{l}1,11 \\
1,08 \\
1,05\end{array}$ & 500 & $\begin{array}{r}0,1 \% \\
1 \% \\
5 \%\end{array}$ \\
\hline nf & $\begin{array}{l}1,63 \\
1,46 \\
1,31\end{array}$ & $\begin{array}{l}1,61 \\
1,44 \\
1,30\end{array}$ & $\begin{array}{l}1,59 \\
1,43 \\
1,29\end{array}$ & $\begin{array}{l}1,51 \\
1,37 \\
1,25\end{array}$ & $\begin{array}{l}1,45 \\
1,33 \\
1,23\end{array}$ & $\begin{array}{l}1,41 \\
1,30 \\
1,20\end{array}$ & $\begin{array}{l}1,38 \\
1,28 \\
1,19\end{array}$ & $\begin{array}{l}1,36 \\
1,26 \\
1,18\end{array}$ & $\begin{array}{l}1,33 \\
1,25 \\
1,17\end{array}$ & $\begin{array}{l}1,31 \\
1,24 \\
1,16\end{array}$ & $\begin{array}{l}1,25 \\
1,19 \\
1,13\end{array}$ & $\begin{array}{l}1,21 \\
1,15 \\
1,11\end{array}$ & $\begin{array}{l}1,00 \\
1,00 \\
1,00\end{array}$ & inf & $\begin{array}{r}0,1 \% \\
1 \% \\
5 \%\end{array}$ \\
\hline nf 1 & 13 & 14 & 15 & 20 & 25 & 30 & 35 & 40 & 45 & 50 & $7 \tilde{5}$ & 100 & $\inf$ & nf 2 & $\mathbf{P}$ \\
\hline
\end{tabular}


T Á B U A

LIMITES BILATERAIS DAS

(Teta-

\begin{tabular}{|c|c|c|c|c|c|c|c|c|c|c|c|c|c|c|}
\hline $\mathbf{P}$ & $\downarrow^{n f 2}$ & 12 & 11 & 10 & 9 & 8 & 7 & 6 & 5 & 4 & 3 & 2 & 1 & $\stackrel{n f 1}{\leftarrow}$ \\
\hline $\begin{array}{c}0,1 \% \\
1 \% \\
5 \%\end{array}$ & 1 & $\begin{array}{l}0,21 \\
0,29 \\
0,39\end{array}$ & $\begin{array}{l}0,21 \\
0,2 ; \\
0,39\end{array}$ & $\begin{array}{l}0,20 \\
0,28 \\
0,38\end{array}$ & $\begin{array}{l}0,19 \\
0,27 \\
0,37\end{array}$ & $\begin{array}{l}0,18 \\
0,26 \\
0,36\end{array}$ & $\begin{array}{l}0,17 \\
0,25 \\
0,35\end{array}$ & $\begin{array}{l}0,15 \\
0,23 \\
0,34\end{array}$ & $\begin{array}{l}0,13 \\
0,21 \\
0,32\end{array}$ & $\begin{array}{l}0,10 \\
0,21 \\
0,30\end{array}$ & $\begin{array}{l}0,06 \\
0,14 \\
0,24\end{array}$ & $\begin{array}{l}0,016 \\
0,08 \\
0,16\end{array}$ & $\begin{array}{l}0,0008 \\
0,008 \\
0,05\end{array}$ & 1 \\
\hline $\begin{array}{c}0,1 \% \\
1 \% \\
5 \%\end{array}$ & 2 & $\begin{array}{l}0,26 \\
0,35 \\
0,44\end{array}$ & $\begin{array}{l}0,25 \\
0,34 \\
0,43\end{array}$ & $\begin{array}{l}0,24 \\
0,33 \\
0,42\end{array}$ & $\begin{array}{l}0,23 \\
0,31 \\
0,41\end{array}$ & $\begin{array}{l}0,21 \\
0,30 \\
0,40\end{array}$ & $\begin{array}{l}0,19 \\
0,28 \\
0,39\end{array}$ & $\begin{array}{l}0,17 \\
0,26 \\
0,37\end{array}$ & $\begin{array}{l}0,14 \\
0,23 \\
0,34\end{array}$ & $\begin{array}{l}0,11 \\
0,19 \\
0,31\end{array}$ & $\begin{array}{l}0,06 \\
0,14 \\
0,24\end{array}$ & $\begin{array}{l}0,016 \\
0,08 \\
0,16\end{array}$ & $\begin{array}{l}0,0007 \\
0,007 \\
0,04\end{array}$ & 2 \\
\hline $\begin{array}{c}0,1 \% \\
1 \% \\
5 \%\end{array}$ & 3 & $\begin{array}{l}0,28 \\
0,37 \\
0,47\end{array}$ & $\begin{array}{l}0,27 \\
0,36 \\
0,46\end{array}$ & $\begin{array}{l}0,26 \\
0,35 \\
0,45\end{array}$ & $\begin{array}{l}0,24 \\
0,34 \\
0,44\end{array}$ & $\begin{array}{l}0,22 \\
0,32 \\
0,43\end{array}$ & $\begin{array}{l}0,20 \\
0,30 \\
0,41\end{array}$ & $\begin{array}{l}0,18 \\
0,28 \\
0,39\end{array}$ & $\begin{array}{l}0,15 \\
0,25 \\
0,36\end{array}$ & $\begin{array}{l}0,11 \\
0,20 \\
0,32\end{array}$ & $\begin{array}{l}0,06 \\
0,14 \\
0,25\end{array}$ & $\begin{array}{l}0,016 \\
0,08 \\
0,16\end{array}$ & $\begin{array}{l}0,0007 \\
0,007 \\
0,04\end{array}$ & 3 \\
\hline $\begin{array}{c}0,1 \% \\
1 \% \\
5 \%\end{array}$ & 4 & $\begin{array}{l}0,30 \\
0,39 \\
0,49\end{array}$ & $\begin{array}{l}0,29 \\
0,38 \\
0,48\end{array}$ & $\begin{array}{l}0,27 \\
0,37 \\
0,47\end{array}$ & $\begin{array}{l}0,25 \\
0,35 \\
0,46\end{array}$ & $\begin{array}{l}0,23 \\
0,34 \\
0,44\end{array}$ & $\begin{array}{l}0,21 \\
0,31 \\
0,42\end{array}$ & $\begin{array}{l}0,18 \\
0,29 \\
0,40\end{array}$ & $\begin{array}{l}0,16 \\
0,25 \\
0,37\end{array}$ & $\begin{array}{l}0,12 \\
0,21 \\
0,32\end{array}$ & $\begin{array}{l}0,06 \\
0,15 \\
0,25\end{array}$ & $\begin{array}{l}0,016 \\
0,08 \\
0,16\end{array}$ & $\begin{array}{l}0,0007 \\
0,007 \\
0,04\end{array}$ & 4 \\
\hline $\begin{array}{c}0,1 \% \\
1 \% \\
5 \%\end{array}$ & 5 & $\begin{array}{l}0,31 \\
0,41 \\
0,51\end{array}$ & $\begin{array}{l}0,30 \\
0,40 \\
0,50\end{array}$ & $\begin{array}{l}0,28 \\
0,38 \\
0,49\end{array}$ & $\begin{array}{l}0,27 \\
0,37 \\
0,47\end{array}$ & $\begin{array}{l}0,24 \\
0,35 \\
0,46\end{array}$ & $\begin{array}{l}0,22 \\
0,32 \\
0,43\end{array}$ & $\begin{array}{l}0,19 \\
0,30 \\
0,41\end{array}$ & $\begin{array}{l}0,16 \\
0,26 \\
0,37\end{array}$ & $\begin{array}{l}0,12 \\
0,20 \\
0,32\end{array}$ & $\begin{array}{l}0,06 \\
0,15 \\
0,25\end{array}$ & $\begin{array}{l}0,016 \\
0,08 \\
0,16\end{array}$ & $\begin{array}{l}0,0007 \\
0,007 \\
0,04\end{array}$ & 5 \\
\hline $\begin{array}{c}0,1 \% \\
1 \% \\
5 \%\end{array}$ & 6 & $\begin{array}{l}0,32 \\
0,42 \\
0,52\end{array}$ & $\begin{array}{l}0,31 \\
0,40 \\
0,51\end{array}$ & $\begin{array}{l}0,29 \\
0,39 \\
0,50\end{array}$ & $\begin{array}{l}0,27 \\
0,37 \\
0,48\end{array}$ & $\begin{array}{l}0,25 \\
0,35 \\
0,47\end{array}$ & $\begin{array}{l}0,23 \\
0,33 \\
0,44\end{array}$ & $\begin{array}{l}0,19 \\
0,30 \\
0,42\end{array}$ & $\begin{array}{l}0,16 \\
0,26 \\
0,38\end{array}$ & $\begin{array}{l}0,12 \\
0,21 \\
0,33\end{array}$ & $\begin{array}{l}0,06 \\
0,15 \\
0,26\end{array}$ & $\begin{array}{l}0,016 \\
0,08 \\
0,16\end{array}$ & $\begin{array}{l}0,0007 \\
0,007 \\
0,04\end{array}$ & 6 \\
\hline $\begin{array}{c}0,1 \% \\
1 \% \\
5 \%\end{array}$ & 7 & $\begin{array}{l}0,33 \\
0,43 \\
0,53\end{array}$ & $\begin{array}{l}0,32 \\
0,41 \\
0,52\end{array}$ & $\begin{array}{l}0,30 \\
0,40 \\
0,50\end{array}$ & $\begin{array}{l}0,28 \\
0,38 \\
0,49\end{array}$ & $\begin{array}{l}0,25 \\
0,36 \\
0,47\end{array}$ & $\begin{array}{l}0,23 \\
0,33 \\
0,45\end{array}$ & $\begin{array}{l}0,20 \\
0,30 \\
0,42\end{array}$ & $\begin{array}{l}0,16 \\
0,27 \\
0,38\end{array}$ & $\begin{array}{l}0,12 \\
0,21 \\
0,33\end{array}$ & $\begin{array}{l}0,06 \\
0,15 \\
0,26\end{array}$ & $\begin{array}{l}0,016 \\
0,08 \\
0,16\end{array}$ & $\begin{array}{l}0,0006 \\
0,006 \\
0,03\end{array}$ & 7 \\
\hline $\begin{array}{c}0,1 \% \\
1 \% \\
5 \%\end{array}$ & 8 & $\begin{array}{l}0,34 \\
0,44 \\
0,53\end{array}$ & $\begin{array}{l}0,32 \\
0,42 \\
0,52\end{array}$ & $\begin{array}{l}0,30 \\
0,40 \\
0,51\end{array}$ & $\begin{array}{l}0,28 \\
0,39 \\
0,50\end{array}$ & $\begin{array}{l}0,26 \\
0,36 \\
0,48\end{array}$ & $\begin{array}{l}0,23 \\
0,34 \\
0,45\end{array}$ & $\begin{array}{l}0,20 \\
0,31 \\
0,43\end{array}$ & $\begin{array}{l}0,17 \\
0,27 \\
0,39\end{array}$ & $\begin{array}{l}0,12 \\
0,22 \\
0,34\end{array}$ & $\begin{array}{l}0,06 \\
0,15 \\
0,26\end{array}$ & $\begin{array}{l}0,016 \\
0,08 \\
0,16\end{array}$ & $\begin{array}{l}0,0006 \\
0,006 \\
0,03\end{array}$ & 8 \\
\hline $\begin{array}{c}0,1 \% \\
1 \% \\
5 \%\end{array}$ & 9 & $\begin{array}{l}0,34 \\
0,44 \\
0,54\end{array}$ & $\begin{array}{l}0,33 \\
0,43 \\
0,53\end{array}$ & $\begin{array}{l}0,31 \\
0,41 \\
0,52\end{array}$ & $\begin{array}{l}0,29 \\
0,39 \\
0,50\end{array}$ & $\begin{array}{l}0,26 \\
0,37 \\
0,48\end{array}$ & $\begin{array}{l}0,24 \\
0,34 \\
0,46\end{array}$ & $\begin{array}{l}0,20 \\
0,31 \\
0,43\end{array}$ & $\begin{array}{l}0,17 \\
0,27 \\
0,39\end{array}$ & $\begin{array}{l}0,12 \\
0,22 \\
0,34\end{array}$ & $\begin{array}{l}0,06 \\
0,15 \\
0,26\end{array}$ & $\begin{array}{l}0,016 \\
0,08 \\
0,16\end{array}$ & $\begin{array}{l}0,0006 \\
0,006 \\
0,03\end{array}$ & 9 \\
\hline $\begin{array}{c}0,1 \% \\
1 \% \\
5 \%\end{array}$ & 10 & $\begin{array}{l}0,35 \\
0,45 \\
0,54\end{array}$ & $\begin{array}{l}0,33 \\
0,43 \\
0,53\end{array}$ & $\begin{array}{l}0,31 \\
0,41 \\
0,52\end{array}$ & $\begin{array}{l}0,29 \\
0,39 \\
0,51\end{array}$ & $\begin{array}{l}0,26 \\
0,37 \\
0,48\end{array}$ & $\begin{array}{l}0,24 \\
0,34 \\
0,46\end{array}$ & $\begin{array}{l}0,20 \\
0,31 \\
0,43\end{array}$ & $\begin{array}{l}0,17 \\
0,27 \\
0,39\end{array}$ & $\begin{array}{l}0,12 \\
0,22 \\
0,34\end{array}$ & $\begin{array}{l}0,06 \\
0,15 \\
0,26\end{array}$ & $\begin{array}{l}0,016 \\
0,08 \\
0,16\end{array}$ & $\begin{array}{l}0,0006 \\
0,006 \\
0,03\end{array}$ & 10 \\
\hline $\begin{array}{c}0,1 \% \\
1 \% \\
5 \%\end{array}$ & 11 & $\begin{array}{l}0,35 \\
0,45 \\
0,55\end{array}$ & $\begin{array}{l}0,33 \\
0,43 \\
0,53\end{array}$ & $\begin{array}{l}0,31 \\
0,41 \\
0,52\end{array}$ & $\begin{array}{l}0,29 \\
0,40 \\
0,51\end{array}$ & $\begin{array}{l}0,26 \\
0,37 \\
0,49\end{array}$ & $\begin{array}{l}0,24 \\
0,35 \\
0,46\end{array}$ & $\begin{array}{l}0,20 \\
0,31 \\
0,43\end{array}$ & $\begin{array}{l}0,17 \\
0,27 \\
0,39\end{array}$ & $\begin{array}{l}0,12 \\
0,22 \\
0,34\end{array}$ & $\begin{array}{l}0,06 \\
0,15 \\
0,26\end{array}$ & $\begin{array}{l}0,016 \\
0,08 \\
0,16\end{array}$ & $\begin{array}{l}0,0006 \\
0,006 \\
0,03\end{array}$ & 11 \\
\hline $\begin{array}{c}0,1 \% \\
1 \% \\
5 \%\end{array}$ & 12 & $\begin{array}{l}0,35 \\
0,46 \\
0,55\end{array}$ & $\begin{array}{l}0,34 \\
0,44 \\
0,54\end{array}$ & $\begin{array}{l}0,32 \\
0,42 \\
0,53\end{array}$ & $\begin{array}{l}0,29 \\
0,40 \\
0,51\end{array}$ & $\begin{array}{l}0,27 \\
0,38 \\
0,49\end{array}$ & $\begin{array}{l}0,24 \\
0,35 \\
0,47\end{array}$ & $\begin{array}{l}0,20 \\
0,32 \\
0,44\end{array}$ & $\begin{array}{l}0,17 \\
0,27 \\
0,39\end{array}$ & $\begin{array}{l}0,12 \\
0,22 \\
0,34\end{array}$ & $\begin{array}{l}0,06 \\
0,15 \\
0,26\end{array}$ & $\begin{array}{l}0,016 \\
0,08 \\
0,16\end{array}$ & $\begin{array}{l}0,0006 \\
0,006 \\
0,03\end{array}$ & 12 \\
\hline $\begin{array}{c}0,1 \% \\
1 \% \\
5 \%\end{array}$ & 13 & $\begin{array}{l}0,36 \\
0,46 \\
0,56\end{array}$ & $\begin{array}{l}0,34 \\
0,44 \\
0,54\end{array}$ & $\begin{array}{l}0,32 \\
0,42 \\
0,53\end{array}$ & $\begin{array}{l}0,30 \\
0,40 \\
0,51\end{array}$ & $\begin{array}{l}0,27 \\
0,38 \\
0,49\end{array}$ & $\begin{array}{l}0,24 \\
0,35 \\
0,47\end{array}$ & $\begin{array}{l}0,20 \\
0,32 \\
0,45\end{array}$ & $\begin{array}{l}0,17 \\
0,27 \\
0,39\end{array}$ & $\begin{array}{l}0,12 \\
0,22 \\
0,34\end{array}$ & $\begin{array}{l}0,06 \\
0,15 \\
0,26\end{array}$ & $\begin{array}{l}0,016 \\
0,08 \\
0,16\end{array}$ & $\begin{array}{l}0,0006 \\
0,006 \\
0,03\end{array}$ & 13 \\
\hline $\begin{array}{c}0,1 \% \\
1 \% \\
5 \%\end{array}$ & 14 & $\begin{array}{l}0,36 \\
0,47 \\
0,56\end{array}$ & $\begin{array}{l}0,34 \\
0,45 \\
0,55\end{array}$ & $\begin{array}{l}0,32 \\
0,43 \\
0,53\end{array}$ & $\begin{array}{l}0,30 \\
0,41 \\
0,52\end{array}$ & $\begin{array}{l}0,27 \\
0,38 \\
0,50\end{array}$ & $\begin{array}{l}0,24 \\
0,35 \\
0,47\end{array}$ & $\begin{array}{l}0,21 \\
0,32 \\
0,44\end{array}$ & $\begin{array}{l}0,17 \\
0,28 \\
0,40\end{array}$ & $\begin{array}{l}0,12 \\
0,23 \\
0,35\end{array}$ & $\begin{array}{l}0,07 \\
0,16 \\
0,27\end{array}$ & $\begin{array}{l}0,016 \\
0,08 \\
0,16\end{array}$ & $\begin{array}{l}0,0006 \\
0,006 \\
0,03\end{array}$ & 14 \\
\hline $\begin{array}{c}0,1 \% \\
1 \% \\
5 \%\end{array}$ & 15 & $\begin{array}{l}0,36 \\
0,47 \\
0,56\end{array}$ & $\begin{array}{l}0,34 \\
0,45 \\
0,56\end{array}$ & $\begin{array}{l}0,32 \\
0,43 \\
0,53\end{array}$ & $\begin{array}{l}0,30 \\
0,41 \\
0,52\end{array}$ & $\begin{array}{l}0,27 \\
0,38 \\
0,50\end{array}$ & $\begin{array}{l}0,24 \\
0,35 \\
0,47\end{array}$ & $\begin{array}{l}0,21 \\
0,32 \\
0,44\end{array}$ & $\begin{array}{l}0,17 \\
0,28 \\
0,40\end{array}$ & $\begin{array}{l}0,12 \\
0,23 \\
0,35\end{array}$ & $\begin{array}{l}0,07 \\
0,16 \\
0,27\end{array}$ & $\begin{array}{l}0,016 \\
0,08 \\
0,16\end{array}$ & $\begin{array}{l}0,0006 \\
0,006 \\
0,03\end{array}$ & 15 \\
\hline $\begin{array}{c}0,1 \% \\
1 \% \\
5 \%\end{array}$ & 20 & $\begin{array}{l}0,37 \\
0,48 \\
0,57\end{array}$ & $\begin{array}{l}0,35 \\
0,46 \\
0,56\end{array}$ & $\begin{array}{l}0,33 \\
0,43 \\
0,54\end{array}$ & $\begin{array}{l}0,30 \\
0,41 \\
0,53\end{array}$ & $\begin{array}{l}0,28 \\
0,39 \\
0,50\end{array}$ & $\begin{array}{l}0,25 \\
0,36 \\
0,47\end{array}$ & $\begin{array}{l}0,21 \\
0,32 \\
0,44\end{array}$ & $\begin{array}{l}0,17 \\
0,28 \\
0,40\end{array}$ & $\begin{array}{l}0,12 \\
0,23 \\
0,35\end{array}$ & $\begin{array}{l}0,07 \\
0,16 \\
0,27\end{array}$ & $\begin{array}{l}0,016 \\
0,08 \\
0,16\end{array}$ & $\begin{array}{l}0,0006 \\
0,006 \\
0,03\end{array}$ & 20 \\
\hline$P$ & $\mathrm{nf}$ & 12 & 11 & 10 & 9 & 8 & 7 & 6 & 5 & 4 & 3 & 2 & 1 & 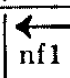 \\
\hline
\end{tabular}




\section{I I a}

\section{DISTRIBUIÇÕES DE FISHER}

teste)

\begin{tabular}{|c|c|c|c|c|c|c|c|c|c|c|c|c|c|c|}
\hline$\stackrel{\text { If } 1}{\rightarrow}$ & 1 & 2 & 3 & 4 & 5 & 6 & 7 & 8 & 9 & 10 & 11 & 12 & nf $2 \downarrow$ & $\mathbf{P}$ \\
\hline 1 & & & & & & $\begin{array}{l}\text { cêre } \\
\text { cêrc } \\
\text { cêr }\end{array}$ & $\begin{array}{l}\text { de } 1 \\
\text { de } \\
\text { de }\end{array}$ & $\begin{array}{l}6,7 \\
6,7 \\
3,3\end{array}$ & & & & & 1 & $\begin{array}{c}0,1 \% \\
1 \% \\
5 \%\end{array}$ \\
\hline \multirow{3}{*}{2} & 60,6 & 60,6 & 60,6 & 60,6 & 60,6 & 60,6 & 60,6 & 60,6 & 60,6 & 60,6 & 60,6 & 60,6 & \multirow{3}{*}{2} & \multirow{3}{*}{$\begin{array}{c}0,1 \% \\
1 \% \\
5 \%\end{array}$} \\
\hline & 12,5 & 12,5 & 12,5 & 12,5 & 12,5 & 12,5 & 12,5 & 12,5 & 12,5 & 12,5 & 12,5 & 12,5 & & \\
\hline & 6,06 & 6,06 & 6,06 & 6,06 & 6,06 & 6,06 & 6,06 & 6,06 & 6,06 & 6,06 & 6,06 & 6,06 & & \\
\hline \multirow{3}{*}{3} & 16,1 & 15,3 & 15,0 & 14,7 & 14,5 & 14,4 & 14,4 & 14,3 & 14,3 & 14,2 & 14,2 & 14,2 & \multirow{3}{*}{3} & \multirow{3}{*}{$\begin{array}{l}0,1 \% \\
1 \% \\
5 \%\end{array}$} \\
\hline & 7,67 & 7,16 & 6,93 & 6,84 & 6,74 & 6.70 & 6,66 & 6,63 & 6,61 & 6,60 & 6,59 & 6,58 & & \\
\hline & 4,50 & 4,00 & 3,92 & 3,88 & 3,86 & 3,84 & 3,83 & 3,82 & 3,81 & 3,80 & 3,79 & 3,79 & & \\
\hline \multirow{3}{*}{4} & 10,2 & 9,38 & 9,03 & 8,80 & 8,63 & 8,53 & 8,47 & 8,41 & 8,36 & 8,32 & 8,29 & 8,26 & \multirow{3}{*}{4} & \multirow{3}{*}{$\begin{array}{c}0,1 \% \\
1 \% \\
5 \%\end{array}$} \\
\hline & 5,67 & 5,17 & 4,96 & 4,84 & 4,74 & 4,70 & 4,66 & 4,63 & 4,61 & 4,60 & 4,58 & 4,56 & & \\
\hline & 3,51 & 3,26 & 3,16 & 3,10 & 3,06 & 3,03 & 3,01 & 2,99 & 2,98 & 2,97 & 2,96 & 2,95 & & \\
\hline \multirow{3}{*}{5} & 7.84 & 7,01 & 6,67 & 6,45 & 6,28 & 6,18 & 6,12 & 6,06 & 6,01 & 5,97 & 5,94 & 5,91 & \multirow{3}{*}{5} & \multirow{3}{*}{$\begin{array}{c}0,1 \% \\
1 \% \\
5 \%\end{array}$} \\
\hline & 4,75 & 4,26 & 4,05 & 3,93 & 3,83 & 3,79 & 3,75 & 3,72 & 3,70 & 3,69 & 3,67 & 3,65 & & \\
\hline & 3,15 & 2,93 & 2,81 & 2,73 & 2,67 & 2,63 & 2,61 & 2,59 & 2,58 & 2,57 & 2,56 & 2,55 & & \\
\hline \multirow{3}{*}{6} & 6,81 & 5,98 & 5,64 & 5,43 & 5,27 & 5,17 & 5,11 & 5,05 & 5,00 & 4,96 & 4,93 & 4,90 & \multirow{3}{*}{6} & \multirow{3}{*}{$\begin{array}{l}0,1 \% \\
1 \% \\
5 \%\end{array}$} \\
\hline & 4,30 & 3,80 & 3,50 & 3,47 & 3,37 & 3,32 & 3,28 & 3,25 & 3,23 & 3,21 & 3,19 & 3,17 & & \\
\hline & 2,94 & 2,69 & 2,57 & 2,48 & 2,42 & 2,38 & 2,36 & 2,33 & 2,32 & 2,31 & 2,30 & 2,29 & & \\
\hline \multirow{3}{*}{7} & 6,05 & 5,23 & 4,89 & 4,68 & 4,52 & 4,42 & 4,36 & 4,30 & 4,25 & 4,21 & 4,18 & 4,15 & \multirow{3}{*}{7} & \multirow{3}{*}{$\begin{array}{c}0,1 \% \\
1 \% \\
5 \%\end{array}$} \\
\hline & 4,03 & 3,52 & 3,31 & 3,18 & 3,08 & 3,03 & 2,99 & 2,95 & 2,93 & 2,91 & 2,89 & 2,87 & & \\
\hline & 2,84 & 2,59 & 2,45 & 2,36 & 2,30 & 2,25 & 2,24 & 2,21 & 2,19 & 2,18 & 2,17 & 2,15 & & \\
\hline & 5,64 & 4,82 & 4,49 & 4,28 & 4,12 & 4,02 & 3,96 & 3,90 & 3,85 & 3,81 & 3,78 & 3.75 & & $0,1 \%$ \\
\hline 8 & 3,82 & 3,32 & 3,10 & 2,97 & 2,87 & 2,82 & 2,77 & 2,74 & 2,71 & 2,69 & 2,67 & 2,65 & 8 & $1 \%$ \\
\hline & 2,75 & 2,49 & 2,35 & 2,25 & 2,19 & 2,15 & 2,12 & 2,10 & 2,08 & 2,07 & 2,06 & 2,04 & & $5 \%$ \\
\hline & 5,28 & 4,47 & 4,14 & 3,93 & 3,77 & 3,67 & 3,61 & 3,55 & 3,50 & 3,46 & 3,43 & 3,40 & & $0.1 \%$ \\
\hline 9 & 3,69 & 3,18 & 2,96 & 2,83 & 2,73 & 2,67 & 2,63 & 2,59 & 2,56 & 2,54 & 2,52 & 2,50 & 9 & $1 \%$ \\
\hline & 2,68 & 2,41 & 2,27 & 2,17 & 2,11 & 2,07 & 2,04 & 2,01 & 1,99 & 1,98 & 1,97 & 1,96 & & $5 \%$ \\
\hline & 5,04 & 4,23 & 3,90 & 3,69 & 3.53 & 3.43 & 3,37 & 3,31 & 3,26 & 3,22 & 3,18 & 3,15 & & $0,1 \%$ \\
\hline 10 & 3,58 & 3,07 & $2,8 \pi$ & 2,72 & 2,62 & 2,57 & 2,52 & 2,48 & 2,45 & 2,43 & 2,41 & 2,39 & 10 & $1 \%$ \\
\hline & 2,63 & 2,36 & 2,22 & 2,12 & 2,06 & 2,02 & 1,99 & 1,96 & 1,94 & 1,93 & 1,92 & 1,90 & & $5 \%$ \\
\hline & 4,84 & 4,03 & 3,70 & 3,49 & 3,34 & 3,24 & 3,17 & 3,11 & 3,07 & 3,03 & 2,99 & 2,96 & & $0,1 \%$ \\
\hline 11 & 3,48 & 3,97 & 2,75 & 2,62 & 2,52 & 2,47 & 2,42 & 2,38 & 2,34 & 2,32 & 2,30 & 2,28 & 11 & $1 \%$ \\
\hline & 2,59 & 2,31 & 2,17 & 2,07 & 2,01 & 1,97 & 1,94 & 1,91 & 1,89 & 1,88 & 1,87 & 1,85 & & $5 \%$ \\
\hline & 4,69 & 3,88 & 3,56 & 3,35 & 3,21 & 3,11 & 3,03 & 2,97 & 2,93 & 2,89 & 2,85 & 2,82 & & $0,1 \%$ \\
\hline 12 & 3,40 & 2,89 & 2,67 & 2,54 & 2,44 & 2,39 & 2,34 & 2,29 & 2,25 & 2,23 & 2,21 & 2,19 & 12 & $1 \%$ \\
\hline & 2,55 & 2,27 & 2,13 & 2,03 & 1,97 & 1,93 & 1,90 & 1,87 & 1,85 & 1,84 & 1,83 & 1,81 & & $5 \%$ \\
\hline & 4,57 & 3,76 & 3,44 & 3,24 & 3,10 & 3,00 & 2,92 & 2,86 & 2,82 & 2,78 & 2,74 & 2,70 & & $0,1 \%$ \\
\hline 13 & 3,37 & 2,86 & 2,64 & 2,51 & 2,41 & 2,35 & 2,30 & 2,25 & 2,21 & 2,19 & 2,17 & 2,15 & 13 & $1 \%$ \\
\hline & 2,52 & 2,24 & 2,10 & 2,00 & 1,94 & 1,90 & 1,87 & 1,84 & 1,82 & 1,81 & 1,80 & 1,78 & & $5 \%$ \\
\hline & 4,48 & 3,67 & 3,35 & 3,15 & 3,01 & 2,91 & 2,84 & 2,78 & 2,73 & 2,69 & 2,65 & 2,62 & & $0,1 \%$ \\
\hline 14 & 3,34 & 2,83 & 2,61 & 2,48 & 2,38 & 2,32 & 2,27 & 2,22 & 2,18 & 2,16 & 2,14 & 2,12 & 14 & $1 \%$ \\
\hline & 2,50 & 2,22 & 2,08 & 1,98 & 1,92 & 1,88 & 1,85 & 1,82 & 1,80 & 1,79 & 1,77 & 1,76 & & $5 \%$ \\
\hline & 4,44 & 3,63 & 3,31 & 3,11 & 2,97 & 2,87 & 2,80 & 2,74 & 2,69 & 2,65 & 2,61 & 2,58 & & $0,1 \%$ \\
\hline 15 & 3,33 & 2,82 & 2,60 & 2,47 & 2,37 & 2,30 & 2,25 & 2,21 & 2,17 & 2,14 & 2,12 & 2,10 & 15 & $1 \%$ \\
\hline & 2,49 & 2,21 & 2,06 & 1,96 & 1,90 & 1,85 & 1,83 & 1,80 & 1,77 & 1,76 & 1,75 & 1,73 & & $5 \%$ \\
\hline & 4,14 & 3,33 & 3,03 & 2,84 & 2,70 & 2,60 & 2,53 & 2,47 & 2,42 & 2,38 & 2,34 & 2,31 & & $0,1 \%$ \\
\hline 20 & 3,15 & 2,64 & 2,42 & 2,29 & 2,19 & 2,13 & 2,07 & 2,03 & 1,99 & 1,97 & 1,94 & 1,92 & 20 & $1 \%$ \\
\hline & 2,42 & 2,13 & 1,98 & 1,88 & 1,81 & 1,77 & 1,73 & 1,71 & 1,68 & 1,67 & 1,65 & 1,64 & & $5 \%$ \\
\hline nf 1 & 1 & 2 & 3 & 4 & 5 & 6 & 7 & 8 & 9 & 10 & 11 & 12 & $\mathrm{nf2}$ & $\mathbf{P}$ \\
\hline
\end{tabular}


$\mathbf{T} \hat{A} \mathbf{B} \quad \mathbf{A}$

LIMITES BIIATHRAIS DAS

(Teta-

\begin{tabular}{|c|c|c|c|c|c|c|c|c|c|c|c|c|c|c|c|}
\hline P & $\downarrow^{n f 2}$ & $\inf$ & 100 & 75 & 50 & 45 & 40 & 35 & 30 & 25 & 20 & 15 & 14 & 13 & $\stackrel{n f 1}{\leftarrow}$ \\
\hline $\begin{array}{r}0.1 \% \\
1 \% \\
5 \%\end{array}$ & 1 & $\begin{array}{l}0,29 \\
0,36 \\
0,45\end{array}$ & $\begin{array}{l}0,28 \\
0,35 \\
0,44\end{array}$ & $\begin{array}{l}0,28 \\
0,35 \\
0,44\end{array}$ & $\begin{array}{l}0,27 \\
0,34 \\
0,43\end{array}$ & $\begin{array}{l}0,27 \\
0,34 \\
0,43\end{array}$ & $\begin{array}{l}0,26 \\
0,34 \\
0,43\end{array}$ & $\begin{array}{l}0,26 \\
0,33 \\
0,43\end{array}$ & $\begin{array}{l}0,26 \\
0,33 \\
0,42\end{array}$ & $\begin{array}{l}0,25 \\
0,32 \\
0,42\end{array}$ & $\begin{array}{l}0,24 \\
0,32 \\
0,41\end{array}$ & $\begin{array}{l}0,23 \\
0,30 \\
0,40\end{array}$ & $\begin{array}{l}0,22 \\
0,30 \\
0,40\end{array}$ & $\begin{array}{l}0,22 \\
0,30 \\
0,40\end{array}$ & 1 \\
\hline $\begin{array}{r}0.1 \% \\
1 \% \\
5 \%\end{array}$ & 2 & $\begin{array}{l}0,37 \\
0,43 \\
0,51\end{array}$ & $\begin{array}{l}0,36 \\
0,43 \\
0,51\end{array}$ & $\begin{array}{l}0,35 \\
0,42 \\
0,50\end{array}$ & $\begin{array}{l}0,34 \\
0,41 \\
0,49\end{array}$ & $\begin{array}{l}0,34 \\
0,41 \\
0,49\end{array}$ & $\begin{array}{l}0,33 \\
0,41 \\
0,49\end{array}$ & $\begin{array}{l}0,33 \\
0,40 \\
0,49\end{array}$ & $\begin{array}{l}0,32 \\
0,40 \\
0,48\end{array}$ & $\begin{array}{l}0,31 \\
0,39 \\
0,18\end{array}$ & $\begin{array}{l}0,30 \\
0,38 \\
0,47\end{array}$ & $\begin{array}{l}0,28 \\
0,35 \\
0,45\end{array}$ & $\begin{array}{l}0,27 \\
0,35 \\
0,45\end{array}$ & $\begin{array}{l}0,27 \\
0,35 \\
0,45\end{array}$ & 2 \\
\hline $\begin{array}{r}0.1 \% \\
1 \% \\
.5 \%\end{array}$ & 3 & $\begin{array}{l}0,41 \\
0,48 \\
0,56\end{array}$ & $\begin{array}{l}0,40 \\
0,47 \\
0,56\end{array}$ & $\begin{array}{l}0,40 \\
0,47 \\
0,54\end{array}$ & $\begin{array}{l}0,38 \\
0,45 \\
0,53\end{array}$ & $\begin{array}{l}0,38 \\
0,45 \\
0,53\end{array}$ & $\begin{array}{l}0,37 \\
0,45 \\
0,53\end{array}$ & $\begin{array}{l}0,36 \\
0,44 \\
0,53\end{array}$ & $\begin{array}{l}0,36 \\
0,43 \\
0,52\end{array}$ & $\begin{array}{l}0,34 \\
0,43 \\
0,52\end{array}$ & $\begin{array}{l}0,33 \\
0,41 \\
0,51\end{array}$ & $\begin{array}{l}0,30 \\
0,38 \\
0,48\end{array}$ & $\begin{array}{l}0,30 \\
0,38 \\
0,48\end{array}$ & $\begin{array}{l}0,29 \\
0,38 \\
0,48\end{array}$ & 3 \\
\hline $\begin{array}{r}0.1 \% \\
1 \% \\
5 \%\end{array}$ & + & $\begin{array}{l}0,45 \\
0,51 \\
0,59\end{array}$ & $\begin{array}{l}0.43 \\
0,50 \\
0,58\end{array}$ & $\begin{array}{l}0,42 \\
0,50 \\
0,57\end{array}$ & $\begin{array}{l}0,41 \\
0,48 \\
0,56\end{array}$ & $\begin{array}{l}0,40 \\
0,48 \\
0,56\end{array}$ & $\begin{array}{l}0,40 \\
0,47 \\
0,56\end{array}$ & $\begin{array}{l}0,39 \\
0,47 \\
0,56\end{array}$ & $\begin{array}{l}0,38 \\
0,46 \\
0,55\end{array}$ & $\begin{array}{l}0,37 \\
0,45 \\
0,54\end{array}$ & $\begin{array}{l}0,35 \\
0,44 \\
0,53\end{array}$ & $\begin{array}{l}0,32 \\
0,40 \\
0,51\end{array}$ & $\begin{array}{l}0.31 \\
0,40 \\
0,51\end{array}$ & $\begin{array}{l}0,31 \\
0,40 \\
0,50\end{array}$ & 4 \\
\hline $\begin{array}{r}0,1 \% \\
1 \% \\
5 \%\end{array}$ & 5 & $\begin{array}{l}0,47 \\
0,54 \\
0,62\end{array}$ & $\begin{array}{l}0,45 \\
0,53 \\
0,61\end{array}$ & $\begin{array}{l}0,45 \\
0,52 \\
0,60\end{array}$ & $\begin{array}{l}0,43 \\
0,51 \\
0,59\end{array}$ & $\begin{array}{l}0,43 \\
0,51 \\
0,59\end{array}$ & $\begin{array}{l}0,42 \\
0,50 \\
0,59\end{array}$ & $\begin{array}{l}0,41 \\
0,49 \\
0,58\end{array}$ & $\begin{array}{l}0,40 \\
0,48 \\
0,58\end{array}$ & $\begin{array}{l}0,39 \\
0,47 \\
0,56\end{array}$ & $\begin{array}{l}0,37 \\
0,16 \\
0,55\end{array}$ & $\begin{array}{l}0,34 \\
0,42 \\
0,53\end{array}$ & $\begin{array}{l}0,33 \\
0,42 \\
0,52\end{array}$ & $\begin{array}{l}0,32 \\
0,41 \\
0,52\end{array}$ & 5 \\
\hline $\begin{array}{r}0.1 \% \\
1 \% \\
5 \%\end{array}$ & 6 & $\begin{array}{l}0,50 \\
0,56 \\
0,64\end{array}$ & $\begin{array}{l}0,47 \\
0,55 \\
0,63\end{array}$ & $\begin{array}{l}0,47 \\
0,54 \\
0,62\end{array}$ & $\begin{array}{l}0,45 \\
0,53 \\
0,61\end{array}$ & $\begin{array}{l}0,44 \\
0,52 \\
0,6 ; 1\end{array}$ & $\begin{array}{l}0,44 \\
0,51 \\
0,61\end{array}$ & $\begin{array}{l}0,43 \\
0,51 \\
0,60\end{array}$ & $\begin{array}{l}0,42 \\
0,50 \\
0,59\end{array}$ & $\begin{array}{l}0,40 \\
0,49 \\
0,58\end{array}$ & $\begin{array}{l}0,38 \\
0,47 \\
0,56\end{array}$ & $\begin{array}{l}0,35 \\
0,43 \\
0,54\end{array}$ & $\begin{array}{l}0,34 \\
0,43 \\
0,53\end{array}$ & $\begin{array}{l}0,33 \\
0,43 \\
0,53\end{array}$ & 6 \\
\hline $\begin{array}{r}0.1 \% \\
1 \% \\
5 \%\end{array}$ & 7 & $\begin{array}{l}0,52 \\
0,58 \\
0,66\end{array}$ & $\begin{array}{l}0,49 \\
0,56 \\
0,64\end{array}$ & $\begin{array}{l}0,48 \\
0,56 \\
0,64\end{array}$ & $\begin{array}{l}0,47 \\
0,54 \\
0,63\end{array}$ & $\begin{array}{l}0,16 \\
0,53 \\
0,62\end{array}$ & $\begin{array}{l}0,45 \\
0,53 \\
0,62\end{array}$ & $\begin{array}{l}0,44 \\
0,52 \\
0,61\end{array}$ & $\begin{array}{l}0,43 \\
0,51 \\
0,61\end{array}$ & $\begin{array}{l}0,41 \\
0,50 \\
0,59\end{array}$ & $\begin{array}{l}0,40 \\
0,48 \\
0,58\end{array}$ & $\begin{array}{l}0,36 \\
0,44 \\
0,55\end{array}$ & $\begin{array}{l}0,35 \\
0,44 \\
0,54\end{array}$ & $\begin{array}{l}0,34 \\
0,43 \\
0,53\end{array}$ & 7 \\
\hline $\begin{array}{r}0,1 \% \\
1 \% \\
5 \%\end{array}$ & 8 & $\begin{array}{l}0,53 \\
0,60 \\
0,68\end{array}$ & $\begin{array}{l}0,51 \\
0,58 \\
0,60\end{array}$ & $\begin{array}{l}0,50 \\
0,57 \\
0,65\end{array}$ & $\begin{array}{l}0,48 \\
0,56 \\
0,64\end{array}$ & $\begin{array}{l}0,17 \\
0,5,5 \\
0,633\end{array}$ & $\begin{array}{l}0,46 \\
0,54 \\
0,63\end{array}$ & $\begin{array}{l}0,45 \\
0,53 \\
0,63\end{array}$ & $\begin{array}{l}0,44 \\
0,52 \\
0,62\end{array}$ & $\begin{array}{l}0,42 \\
0,51 \\
0,60\end{array}$ & $\begin{array}{l}0,40 \\
0,49 \\
0,58\end{array}$ & $\begin{array}{l}0,36 \\
0,45 \\
0,56\end{array}$ & $\begin{array}{l}0,36 \\
0,45 \\
0,55\end{array}$ & $\begin{array}{l}0,35 \\
0,44 \\
0,54\end{array}$ & 8 \\
\hline $\begin{array}{r}0.1 \% \\
1 \% \\
5 \%\end{array}$ & 9 & $\begin{array}{l}0,55 \\
0,61 \\
0,68\end{array}$ & $\begin{array}{l}0,52 \\
0,60 \\
0,67\end{array}$ & $\begin{array}{l}0,51 \\
0,59 \\
0,66\end{array}$ & $\begin{array}{l}0,49 \\
0,57 \\
0,65\end{array}$ & $\begin{array}{l}0,48 \\
0,56 \\
0,65\end{array}$ & $\begin{array}{l}0,47 \\
0,55 \\
0,64\end{array}$ & $\begin{array}{l}0,47 \\
0,54 \\
0,64\end{array}$ & $\begin{array}{l}0,45 \\
0,53 \\
0,63\end{array}$ & $\begin{array}{l}0,43 \\
0,52 \\
0,61\end{array}$ & $\begin{array}{l}0,411 \\
0,50 \\
0,60\end{array}$ & $\begin{array}{l}0,37 \\
0,46 \\
0,56\end{array}$ & $\begin{array}{l}0,37 \\
0,46 \\
0,56\end{array}$ & $\begin{array}{l}0,35 \\
0,45 \\
0,55\end{array}$ & 9 \\
\hline $\begin{array}{r}0.1 \% \\
1 \% \\
5 \%\end{array}$ & 10 & $\begin{array}{l}0,56 \\
0,63 \\
0,69\end{array}$ & $\begin{array}{l}0,53 \\
0,611 \\
0,68\end{array}$ & $\begin{array}{l}0,52 \\
0,60 \\
0,67\end{array}$ & $\begin{array}{l}0,50 \\
0,58 \\
0,65\end{array}$ & $\begin{array}{l}0,49 \\
0,57 \\
0,655\end{array}$ & $\begin{array}{l}0,48 \\
0,56 \\
0,65\end{array}$ & $\begin{array}{l}0,47 \\
0,5 i \\
0,64\end{array}$ & $\begin{array}{l}0,46 \\
0,54 \\
0,63\end{array}$ & $\begin{array}{l}0,44 \\
0,52 \\
0,611\end{array}$ & $\begin{array}{l}0.42 \\
0.51 \\
0.60\end{array}$ & $\begin{array}{l}0,38 \\
0,47 \\
0,57\end{array}$ & $\begin{array}{l}0,37 \\
0,46 \\
0,56\end{array}$ & $\begin{array}{l}0,36 \\
0,46 \\
0,55\end{array}$ & 10 \\
\hline $\begin{array}{r}0.1 \% \\
1 \% \\
5 \%\end{array}$ & 11 & $\begin{array}{l}0,57 \\
0,64 \\
0,70\end{array}$ & $\begin{array}{l}0,54 \\
0,62 \\
0,68\end{array}$ & $\begin{array}{l}0,53 \\
0,61 \\
0,68\end{array}$ & $\begin{array}{l}0,51 \\
0,59 \\
0,66\end{array}$ & $\begin{array}{l}0,50 \\
0,58 \\
0,60\end{array}$ & $\begin{array}{l}0,49 \\
0,17 \\
0,65\end{array}$ & $\begin{array}{l}0,48 \\
0,56 \\
0,65\end{array}$ & $\begin{array}{l}0,47 \\
0.50 \\
0,64\end{array}$ & $\begin{array}{l}0,40 \\
0,54 \\
0,62\end{array}$ & $\begin{array}{l}0,43 \\
0,52 \\
0,61\end{array}$ & $\begin{array}{l}0,38 \\
0,47 \\
0,57\end{array}$ & $\begin{array}{l}0.38 \\
0.47 \\
0,56\end{array}$ & $\begin{array}{l}0,36 \\
0,46 \\
0,56\end{array}$ & 11 \\
\hline $\begin{array}{r}0.1 \% \\
1 \% \\
5 \%\end{array}$ & 12 & $\begin{array}{l}0,59 \\
0,65 \\
0,71\end{array}$ & $\begin{array}{l}0,55 \\
0,63 \\
0,69\end{array}$ & $\begin{array}{l}0,54 \\
0,62 \\
0,68\end{array}$ & $\begin{array}{l}0.52 \\
0,60 \\
0,67\end{array}$ & $\begin{array}{l}0,51 \\
0,50 \\
0,67\end{array}$ & $\begin{array}{l}0.50 \\
0,58 \\
0,60\end{array}$ & $\begin{array}{l}0,49 \\
0,57 \\
0,65\end{array}$ & $\begin{array}{l}0,18 \\
0,56 \\
0,65\end{array}$ & $\begin{array}{l}0,40 \\
0,54 \\
0,63\end{array}$ & $\begin{array}{l}0,13 \\
0,52 \\
0,61\end{array}$ & $\begin{array}{l}0,39 \\
0,48 \\
0,58\end{array}$ & $\begin{array}{l}0,38 \\
0,47 \\
0,57\end{array}$ & $\begin{array}{l}0,37 \\
0,47 \\
0,56\end{array}$ & 12 \\
\hline $\begin{array}{r}0,1 \% \\
1 \% \\
5 \%\end{array}$ & 13 & $\begin{array}{l}0,60 \\
0,66 \\
0,72\end{array}$ & $\begin{array}{l}0,56 \\
0,63 \\
0,70\end{array}$ & $\begin{array}{l}0,5,3 \\
0,63 \\
0,69\end{array}$ & $\begin{array}{l}0,53 \\
0,60 \\
0,68\end{array}$ & $\begin{array}{l}0,52 \\
0,60 \\
0,68\end{array}$ & $\begin{array}{l}0,51 \\
0,59 \\
0,67\end{array}$ & $\begin{array}{l}0,50 \\
0,58 \\
0,60\end{array}$ & $\begin{array}{l}0,48 \\
0,56 \\
0,65\end{array}$ & $\begin{array}{l}0,46 \\
0,5 \tilde{5} \\
0,6.4\end{array}$ & $\begin{array}{l}0,44 \\
0,53 \\
0,612\end{array}$ & $\begin{array}{l}0,30 \\
0,48 \\
0,-8\end{array}$ & $\begin{array}{l}0.39 \\
0.48 \\
0,57\end{array}$ & $\begin{array}{l}0,37 \\
0,47 \\
0,56\end{array}$ & 13 \\
\hline $\begin{array}{r}0.1 \% \\
1 \% \\
5 \%\end{array}$ & 14 & $\begin{array}{l}0,61 \\
0,67 \\
0,73\end{array}$ & $\begin{array}{l}0,57 \\
0,6.4 \\
0,71\end{array}$ & $\begin{array}{l}0,56 \\
0,63 \\
0,70\end{array}$ & $\begin{array}{l}0,53 \\
0,61 \\
0,68\end{array}$ & $\begin{array}{l}0,52 \\
0,60 \\
0,68\end{array}$ & $\begin{array}{l}0,51 \\
0,60 \\
0,68\end{array}$ & $\begin{array}{l}0,50 \\
0,58 \\
0,67\end{array}$ & $\begin{array}{l}0,49 \\
0,57 \\
0,66\end{array}$ & $\begin{array}{l}0,47 \\
0,56 \\
0,64\end{array}$ & $\begin{array}{l}0,44 \\
0,53 \\
0,4 i 2\end{array}$ & $\begin{array}{l}0.10 \\
0.49 \\
0.58\end{array}$ & $\begin{array}{l}0,39 \\
0,48 \\
0,58\end{array}$ & $\begin{array}{l}0,38 \\
0,47 \\
0,57\end{array}$ & 14 \\
\hline $\begin{array}{r}0,1 \% \\
1 \% \\
5 \%\end{array}$ & 15 & $\begin{array}{l}0,61 \\
0,68 \\
0,74\end{array}$ & $\begin{array}{l}0,57 \\
0,6.7 \\
0,71\end{array}$ & $\begin{array}{l}0,50 \\
0,64 \\
0,70\end{array}$ & $\begin{array}{l}0,54 \\
0,62 \\
0,69\end{array}$ & $\begin{array}{l}0, \pi 3 \\
0,61 \\
0,69\end{array}$ & $\begin{array}{l}0,52 \\
0,60 \\
0,68\end{array}$ & $\begin{array}{l}0,31 \\
0,59 \\
0,67\end{array}$ & $\begin{array}{l}0,46 \\
0,57 \\
0,66\end{array}$ & $\begin{array}{l}0,47 \\
0,56 \\
0,65\end{array}$ & $\begin{array}{l}0,4.4 \\
0,53 \\
0,633\end{array}$ & $\begin{array}{l}0.40 \\
0.49 \\
0,59\end{array}$ & $\begin{array}{l}0,39 \\
0,48 \\
0,58\end{array}$ & $\begin{array}{l}0,38 \\
0,48 \\
0,57\end{array}$ & 15 \\
\hline $\begin{array}{r}0.1 \% \\
1 \% \\
5 \%\end{array}$ & 20 & $\begin{array}{l}0,65 \\
0,70 \\
0,76\end{array}$ & $\begin{array}{l}0,60 \\
0,67 \\
0,74\end{array}$ & $\begin{array}{l}0,59 \\
0,66 \\
0,72\end{array}$ & $\begin{array}{l}0,56 \\
0,63 \\
0,70\end{array}$ & $\begin{array}{l}0,55 \\
0,6.3 \\
0,70\end{array}$ & $\begin{array}{l}0,54 \\
0,61 \\
0,69\end{array}$ & $\begin{array}{l}0,53 \\
0,60 \\
0,68\end{array}$ & $\begin{array}{l}0,51 \\
0,59 \\
0,68\end{array}$ & $\begin{array}{l}0,49 \\
0,57 \\
0,66\end{array}$ & $\begin{array}{l}0,40 \\
0,55 \\
0,64\end{array}$ & $\begin{array}{l}0,41 \\
0,50 \\
0,60\end{array}$ & $\begin{array}{l}0,40 \\
0,49 \\
0,59\end{array}$ & $\begin{array}{l}0,39 \\
0,49 \\
0,58\end{array}$ & 20 \\
\hline$P$ & $n f 2$ & inf & 100 & 75 & 50 & 45 & 40 & 35 & 30 & 25 & 20 & 15 & 14 & 13 & $\stackrel{\leftarrow}{\text { if } 1}$ \\
\hline
\end{tabular}




\section{I I b}

DISTRIBUIÇOES IDE FISIIER

\section{teste)}

\begin{tabular}{|c|c|c|c|c|c|c|c|c|c|c|c|c|c|c|c|}
\hline$\stackrel{\mathrm{ff}}{\rightarrow}$ & 13 & 14 & 15) & 20 & 25 & 30 & 35 & 40 & 45 & 50 & 75 & 100 & $\inf f$ & $112 \downarrow$ & $\mathrm{I}^{\prime}$ \\
\hline 1 & & & & & & & $\begin{array}{l}\text { cêrea } \\
\text { cêrca } \\
\text { cêrea }\end{array}$ & $\begin{array}{l}\text { de } 1 . \\
\text { de } \\
\text { de }\end{array}$ & $\begin{array}{l}6,7 \\
6,7 \\
3,3\end{array}$ & & & & & ] & $\begin{array}{r}0,1 \\
1 \\
5\end{array}$ \\
\hline \multirow{2}{*}{2} & 60,6 & 60,6 & 60,6 & 60,6 & 60,6 & 60,6 & 60,6 & 60,6 & 60,6 & 60,6 & 60,6 & 60,6 & 60,6 & & 0,1 \\
\hline & 6,06 & $\begin{array}{l}2,06 \\
6,06\end{array}$ & 6,06 & 6,06 & $\begin{array}{l}2,6 \\
6,06\end{array}$ & 6,06 & $\begin{array}{l}2,5 \\
6,06\end{array}$ & $\begin{array}{l}12,5 \\
6,06\end{array}$ & $\begin{array}{l}12,5 \\
6,06\end{array}$ & $\begin{array}{l}12,5 \\
6,06\end{array}$ & $\begin{array}{l}T 2, i \\
6,06\end{array}$ & 6,06 & 6,06 & 2 & 1 \\
\hline \multirow{3}{*}{3} & 14,2 & 14,2 & 14,1 & 14,0 & 14,0 & 14,0 & 14,0 & 14,0 & 14,0 & 14,0 & 14,0 & 13,9 & 13,9 & & 0,19 \\
\hline & & & & & & & & 6,49 & 6,4 & 6,4 & & 6,48 & 6,47 & 3 & \\
\hline & 3,79 & 3,79 & 3,79 & 3,78 & 3,78 & 3,78 & 3,77 & 3,77 & 3,77 & 3,76 & 3,76 & 3,76 & 3,75 & & \\
\hline \multirow{3}{*}{4} & 8,24 & 8,23 & 8.22 & 8,16 & 8,11 & 8,08 & 8,05 & 8,04 & 8,04 & 8,03 & 8,00 & 7,98 & 7,96 & & $0,1 \%$ \\
\hline & 4,5 & 4,5 & 4,5 & 4,5 & 4,48 & & 4,46 & & 4, & & & 4,44 & 4,43 & 4 & \\
\hline & 2,94 & 2,94 & 2,93 & 2,92 & 2,92 & 2,91 & 2,91 & 2,91 & 2,91 & 2,90 & 2,89 & 2,89 & 2,87 & & \\
\hline \multirow{3}{*}{5} & 5,89 & 5,87 & 5,86 & 5,80 & 5,75 & 5,72 & 5,69 & 5,68 & 5,68 & 5,67 & 5,64 & 5,62 & 5,60 & & $0,1 \%$ \\
\hline & 3,64 & 3,63 & 3,6 & 3.5 & $3,5,5$ & 3,54 & 3,53 & 3,52 & 3,52 & 3,5 & 3,51 & 3,51 & 3,50 & 5 & \\
\hline & 2,54 & 2,53 & 2,53 & 2,52 & 2,50 & 2,50 & 2,49 & 2,48 & 2,48 & 2,48 & 2,47 & 2,47 & 2,46 & & $5 \%$ \\
\hline \multirow{3}{*}{6} & 4,88 & 4,86 & 4,8 & 4,78 & 4,73 & 4,70 & 4,67 & 4,66 & 4,66 & 4,65 & 4,62 & 4,60 & 4,58 & & $0,1 \%$ \\
\hline & 3,1 & & & & & & & & 3,8 & & & 3,0 & 3,00 & 6 & \\
\hline & 2,28 & 2,26 & 2,26 & 2,25 & 2,23 & 2,22 & 2,21 & 2,21 & 2,20 & 2,20 & 2,19 & 2,19 & 2,18 & & \\
\hline \multirow{3}{*}{7} & 4,13 & 4,11 & 4,09 & 4,03 & 3,98 & $3,9 \tilde{5}$ & 3,92 & 3,91 & 3,91 & 3,90 & 3,87 & 3,85 & $3,8.3$ & & $0,1 \%$ \\
\hline & 2,8 & 2,8 & & 2,7 & 2,76 & 2,7 & 2,7 & 2,7 & 2,7 & 2,7 & & & 2,68 & 7 & $1 \%$ \\
\hline & 2,14 & 2,13 & 2,13 & 2,11 & 2,09 & 2,08 & 2,07 & 2,07 & 2,06 & 2,06 & 2,05 & 2,05 & 2,04 & & \\
\hline \multirow{3}{*}{8} & 3,73 & 3,71 & 3,69 & 3,68 & 3,58 & 3,55 & 3,52 & 3,51 & 3,5 & 3,5 & 3,47 & 3, & 3,43 & & $0.1 \%$ \\
\hline & 2,6 & & & & & & & & & & & & & 8 & \\
\hline & 2,03 & 2,02 & 2,01 & 1,99 & 1,97 & 1,96 & 1,95 & 1,95 & 1,94 & 1,94 & 1,93 & 1,93 & 1,92 & & \\
\hline \multirow{3}{*}{9} & 3,38 & 3,36 & 3,34 & 3,28 & 3,23 & & 317 & 3,16 & & 315 & & 3,10 & 3,08 & & $0,1 \%$ \\
\hline & 2,4 & & & & & & & & 2,3 & & & & 2,29 & 9 & $1 \%$ \\
\hline & 1,94 & 1,93 & 1,92 & 1,90 & 1,88 & 1,87 & 1,86 & 1,86 & 1,85 & $1,8 \tilde{5}$ & 1,84 & 1,84 & 1,83 & & \\
\hline \multirow{3}{*}{10} & 3,13 & 3,1 & 3,0 & 3,0 & $2, ?$ & 2,9 & 2,9 & 2,9 & 2, & $2, !$ & & & 2,83 & & \\
\hline & 2,4 & & & & & & & & & & & & 2,17 & 10 & 1 \\
\hline & 1,89 & 1,88 & 1,87 & 1,85 & 1,83 & 1,82 & 1,81 & 1,80 & 1,80 & 1,79 & 1,78 & 1,78 & 1,77 & & \\
\hline \multirow{3}{*}{11} & 2,9 & 2,91 & & & & & & & & & & & 2,63 & & $1 c$ \\
\hline & 2,2 & & 2, & & & & & & & & & & 2,06 & 11 & $1 \%$ \\
\hline & 1,84 & 1,83 & 1,82 & 1,80 & 1,78 & 1,77 & 1,76 & 1,75 & 1,75 & 1,74 & 1,73 & 1,73 & 1,72 & & \\
\hline \multirow{3}{*}{12} & 2,79 & 2,7 & 2,7 & 2,6 & 2,6 & 2,6 & 2,5 & 2,5 & 2,5 & 2,4 & 2,5 & & 2,49 & & $0.1 \%$ \\
\hline & & & & & & & & & & & & & 1,96 & 12 & 1 \\
\hline & 1,80 & 1,79 & 1,78 & 1,76 & 1,74 & 1,73 & 1,72 & 1,71 & 1,70 & 1,70 & 1,69 & 1,69 & 1,68 & & $5 \%$ \\
\hline \multirow{3}{*}{13} & 2,68 & 2,60 & & & 2,53 & & & & & & & & 2,37 & & $0,1 \%$ \\
\hline & 2,1 & & & & & & & & & & & & & 13 & \\
\hline & 1,77 & 1,76 & 1,75 & 1,72 & 1,70 & 1,69 & 1,68 & 1,67 & 1,67 & 1,66 & 1,65 & 1,65 & 1,64 & & \\
\hline \multirow{3}{*}{14} & 2,5 & 2,5 & 2,8 & & 2,4 & 2,4 & 2,3 & 2,8 & & & & & 2,28 & & $0,1 \%$ \\
\hline & & & & & & & & & & & & & 1,84 & 14 & \\
\hline & 1,74 & 1,73 & 1,72 & 1,70 & 1,68 & 1,67 & 1,66 & 1,65 & 1,64 & 1,64 & 1,63 & 1,62 & 1,61 & & $5 \%$ \\
\hline \multirow{3}{*}{15} & 2,55 & 2,5 & 2,52 & & & & & 2,32 & & & & 2,2 & 2,24 & & \\
\hline & & & & & & & 1,4 & & & & & & & 15 & \\
\hline & 1,72 & 1,71 & 1,70 & 1,67 & 1,65 & 1,64 & 1,63 & 1,62 & 1,62 & 1,61 & 1,60 & 1,59 & 1,58 & & $5 \%$ \\
\hline \multirow{3}{*}{20} & 2,28 & 2,26 & 2,25 & 2,1 & 2,13 & 2,10 & 2,07 & 2,05 & 2,05 & 2,04 & 2,0 & 1,99 & 1,98 & & \\
\hline & 1,90 & 1,88 & & & & & & & 1,74 & 1,73 & & 1,68 & 1,68 & 20 & $\begin{array}{l}1 \% \\
5 \%\end{array}$ \\
\hline & 1,62 & 1,61 & 1,60 & 1,57 & 1,55 & 1,54 & 1,53 & 1,52 & 1,52 & 1,51 & 1,50 & 1,49 & 1,47 & & \\
\hline $\overrightarrow{n f 1}$ & 13 & 14 & 15 & 20 & 25 & 20 & 35 & 40 & 45 & 50 & 75 & 100 & $\inf$ & $\mathrm{nf}_{2} \uparrow$ & $\mathbf{P}$ \\
\hline
\end{tabular}


T Á B U A

LIMITES BILATERAIS DAS

(Teta-

\begin{tabular}{|c|c|c|c|c|c|c|c|c|c|c|c|c|c|c|}
\hline $\mathbf{P}$ & $\downarrow^{\mathrm{nf} 2}$ & 12 & 11 & 10 & 9 & 8 & 7 & 6 & 5 & 4 & 3 & .2 & 1 & $\stackrel{n f 1}{\longleftarrow}$ \\
\hline $\begin{array}{r}0,1 \% \\
1 \% \\
5 \%\end{array}$ & 20 & $\begin{array}{l}0,37 \\
0,48 \\
0,57\end{array}$ & $\begin{array}{l}0,35 \\
0,46 \\
0,56\end{array}$ & $\begin{array}{l}0,33 \\
0,43 \\
0,54\end{array}$ & $\begin{array}{l}0,30 \\
0,41 \\
0,53\end{array}$ & $\begin{array}{l}0,28 \\
0,39 \\
0,50\end{array}$ & $\begin{array}{l}0,25 \\
0,36 \\
0,47\end{array}$ & $\begin{array}{l}0,21 \\
0,32 \\
0,44\end{array}$ & $\begin{array}{l}0,17 \\
0,28 \\
0,40\end{array}$ & $\begin{array}{l}0,16 \\
0,23 \\
0,35\end{array}$ & $\begin{array}{l}0,07 \\
0,16 \\
0,27\end{array}$ & $\begin{array}{l}0,02 \\
0,08 \\
0,16\end{array}$ & $\begin{array}{l}0,001 \\
0,066 \\
0,03\end{array}$ & 20 \\
\hline $\begin{array}{r}0,1 \% \\
1 \% \\
5 \%\end{array}$ & 25 & $\begin{array}{l}0,38 \\
0,48 \\
0,57\end{array}$ & $\begin{array}{l}0,36 \\
0,46 \\
0,56\end{array}$ & $\begin{array}{l}0,34 \\
0,44 \\
0,55\end{array}$ & $\begin{array}{l}0,31 \\
0,42 \\
0,53\end{array}$ & $\begin{array}{l}0,28 \\
0,40 \\
0,51\end{array}$ & $\begin{array}{l}0,25 \\
0,36 \\
0,48\end{array}$ & $\begin{array}{l}0,21 \\
0,33 \\
0,45\end{array}$ & $\begin{array}{l}0,17 \\
0,28 \\
0,40\end{array}$ & $\begin{array}{l}0,12 \\
0,23 \\
0,35\end{array}$ & $\begin{array}{l}0,06 \\
0,16 \\
0,27\end{array}$ & $\begin{array}{l}0,02 \\
0,08 \\
0,16\end{array}$ & $\begin{array}{l}0,001 \\
0,006 \\
0,03\end{array}$ & 25 \\
\hline $\begin{array}{r}0,1 \% \\
1 \% \\
5 \%\end{array}$ & 30 & $\begin{array}{l}0,38 \\
0,49 \\
0,58\end{array}$ & $\begin{array}{l}0,36 \\
0,47 \\
0,56\end{array}$ & $\begin{array}{l}0,34 \\
0,44 \\
0,55\end{array}$ & $\begin{array}{l}0,31 \\
0,42 \\
0,53\end{array}$ & $\begin{array}{l}0,28 \\
0,40 \\
0,51\end{array}$ & $\begin{array}{l}0,25 \\
0,36 \\
0,48\end{array}$ & $\begin{array}{l}0,21 \\
0,33 \\
0,45\end{array}$ & $\begin{array}{l}0,17 \\
0,28 \\
0,40\end{array}$ & $\begin{array}{l}0,12 \\
0,23 \\
0,35\end{array}$ & $\begin{array}{l}0,07 \\
0,17 \\
0,27\end{array}$ & $\begin{array}{l}0,02 \\
0,08 \\
0,16\end{array}$ & $\begin{array}{l}0,001 \\
0,006 \\
0,03\end{array}$ & 30 \\
\hline $\begin{array}{r}0,1 \% \\
1 \% \\
5 \%\end{array}$ & 35 & $\begin{array}{l}0,39 \\
0,49 \\
0,58\end{array}$ & $\begin{array}{l}0,37 \\
0,47 \\
0,57\end{array}$ & $\begin{array}{l}0,34 \\
0,45 \\
0,55\end{array}$ & $\begin{array}{l}0,32 \\
0,43 \\
0,54\end{array}$ & $\begin{array}{l}0,28 \\
0,40 \\
0,51\end{array}$ & $\begin{array}{l}0,26 \\
0,37 \\
0,48\end{array}$ & $\begin{array}{l}0,21 \\
0,33 \\
0,45\end{array}$ & $\begin{array}{l}0,18 \\
0,28 \\
0,40\end{array}$ & $\begin{array}{l}0,13 \\
0,23 \\
0,35\end{array}$ & $\begin{array}{l}0,07 \\
0,16 \\
0,27\end{array}$ & $\begin{array}{l}0,02 \\
0,08 \\
0,16\end{array}$ & $\begin{array}{l}0,001 \\
0,006 \\
0,03\end{array}$ & 35 \\
\hline $\begin{array}{r}0,1 \% \\
1 \% \\
5 \%\end{array}$ & 40 & $\begin{array}{l}0,39 \\
0,49 \\
0,58\end{array}$ & $\begin{array}{l}0,37 \\
0,47 \\
0,57\end{array}$ & $\begin{array}{l}0,34 \\
0,45 \\
0,56\end{array}$ & $\begin{array}{l}0,32 \\
0,43 \\
0,54\end{array}$ & $\begin{array}{l}0,28 \\
0,40 \\
0,51\end{array}$ & $\begin{array}{l}0,26 \\
0,37 \\
0,48\end{array}$ & $\begin{array}{l}0,21 \\
0,33 \\
0,45\end{array}$ & $\begin{array}{l}0,18 \\
0,28 \\
0,40\end{array}$ & $\begin{array}{l}0,13 \\
0,23 \\
0,35\end{array}$ & $\begin{array}{l}0,07 \\
0,16 \\
0,27\end{array}$ & $\begin{array}{l}0,02 \\
0,08 \\
0,16\end{array}$ & $\begin{array}{l}0,001 \\
0,006 \\
0,03\end{array}$ & 40 \\
\hline $\begin{array}{r}0,1 \% \\
1 \% \\
5 \%\end{array}$ & 45 & $\begin{array}{l}0,39 \\
0,50 \\
0,59\end{array}$ & $\begin{array}{l}0,37 \\
0,47 \\
0,57\end{array}$ & $\begin{array}{l}0,34 \\
0,45 \\
0,56\end{array}$ & $\begin{array}{l}0,32 \\
0,43 \\
0,54\end{array}$ & $\begin{array}{l}0,28 \\
0,40 \\
0,52\end{array}$ & $\begin{array}{l}0,26 \\
0,37 \\
0,49\end{array}$ & $\begin{array}{l}0,21 \\
0,33 \\
0,45\end{array}$ & $\begin{array}{l}0,18 \\
0,28 \\
0,40\end{array}$ & $\begin{array}{l}0,13 \\
0,23 \\
0,35\end{array}$ & $\begin{array}{l}0,07 \\
0,16 \\
0,27\end{array}$ & $\begin{array}{l}0,02 \\
0,08 \\
0,16\end{array}$ & $\begin{array}{l}0,001 \\
0,006 \\
0,03\end{array}$ & 45 \\
\hline $\begin{array}{r}0,1 \% \\
1 \% \\
5 \%\end{array}$ & 50 & $\begin{array}{l}0,39 \\
0,50 \\
0,59\end{array}$ & $\begin{array}{l}0,37 \\
0,47 \\
0,57\end{array}$ & $\begin{array}{l}0,34 \\
0,45 \\
0,56\end{array}$ & $\begin{array}{l}0,32 \\
0,43 \\
0,54\end{array}$ & $\begin{array}{l}0,29 \\
0,40 \\
0,52\end{array}$ & $\begin{array}{l}0,26 \\
0,37 \\
0,49\end{array}$ & $\begin{array}{l}0,22 \\
0,33 \\
0,45\end{array}$ & $\begin{array}{l}0,18 \\
0,28 \\
0,40\end{array}$ & $\begin{array}{l}0,13 \\
0,23 \\
0,35\end{array}$ & $\begin{array}{l}0,07 \\
0,16 \\
0,27\end{array}$ & $\begin{array}{l}0,02 \\
0,03 \\
0,16\end{array}$ & $\begin{array}{l}0,001 \\
0,006 \\
0,03\end{array}$ & 50 \\
\hline $\begin{array}{r}0,1 \% \\
1 \% \\
5 \%\end{array}$ & 75 & $\begin{array}{l}0,40 \\
0,50 \\
0,59\end{array}$ & $\begin{array}{l}0,37 \\
0,49 \\
0,58\end{array}$ & $\begin{array}{l}0,35 \\
0,45 \\
0,56\end{array}$ & $\begin{array}{l}0,32 \\
0,43 \\
0,54\end{array}$ & $\begin{array}{l}0,29 \\
0,41 \\
0,52\end{array}$ & $\begin{array}{l}0,26 \\
0,37 \\
0,49\end{array}$ & $\begin{array}{l}0,22 \\
0,33 \\
0,46\end{array}$ & $\begin{array}{l}0,18 \\
0,28 \\
0,40\end{array}$ & $\begin{array}{l}0,13 \\
0,23 \\
0,35\end{array}$ & $\begin{array}{l}0,07 \\
0,16 \\
0,27\end{array}$ & $\begin{array}{l}0,02 \\
0,08 \\
0,16\end{array}$ & $\begin{array}{l}0,001 \\
0,006 \\
0,03\end{array}$ & 75 \\
\hline $\begin{array}{r}0.1 \% \\
1 \% \\
5 \%\end{array}$ & 100 & $\begin{array}{l}0,40 \\
0,5 . \\
0,59\end{array}$ & $\begin{array}{l}0,38 \\
0,48 \\
0,58\end{array}$ & $\begin{array}{l}0,35 \\
0,46 \\
0,56\end{array}$ & $\begin{array}{l}0,32 \\
0,43 \\
0,54\end{array}$ & $\begin{array}{l}0,29 \\
0,41 \\
0,51\end{array}$ & $\begin{array}{l}0,26 \\
0,37 \\
0,49\end{array}$ & $\begin{array}{l}0,22 \\
0,33 \\
0,46\end{array}$ & $\begin{array}{l}0,18 \\
0,28 \\
0,40\end{array}$ & $\begin{array}{l}0,13 \\
0,23 \\
0,35\end{array}$ & $\begin{array}{l}0,07 \\
0,16 \\
0,27\end{array}$ & $\begin{array}{l}0,02 \\
0,08 \\
0,16\end{array}$ & $\begin{array}{l}0,001 \\
0,006 \\
0,03\end{array}$ & 100 \\
\hline $\begin{array}{r}0,1 \% \\
1 \% \\
5 \%\end{array}$ & 500 & $\begin{array}{l}0,40 \\
0,51 \\
0,59\end{array}$ & $\begin{array}{l}0,38 \\
0,49 \\
0,58\end{array}$ & $\begin{array}{l}0,35 \\
0,46 \\
0,56\end{array}$ & $\begin{array}{l}0,32 \\
0,44 \\
0,54\end{array}$ & $\begin{array}{l}0,29 \\
0,41 \\
0,52\end{array}$ & $\begin{array}{l}0,26 \\
0,37 \\
0,49\end{array}$ & $\begin{array}{l}0,22 \\
0,33 \\
0,46\end{array}$ & $\begin{array}{l}0,18 \\
0,29 \\
0,41\end{array}$ & $\begin{array}{l}0,13 \\
0,23 \\
0,35\end{array}$ & $\begin{array}{l}0,07 \\
0,16 \\
0,27\end{array}$ & $\begin{array}{l}0,02 \\
0,08 \\
0,16\end{array}$ & $\begin{array}{l}0,001 \\
0,006 \\
0,03\end{array}$ & $5 \mathrm{CO}$ \\
\hline $\begin{array}{r}0.1 \% \\
1 \% \\
5 \%\end{array}$ & $\inf$ & $\begin{array}{l}0,40 \\
0,51 \\
0,60\end{array}$ & $\begin{array}{l}0,38 \\
0,49 \\
0,58\end{array}$ & $\begin{array}{l}0,35 \\
0,46 \\
0,56\end{array}$ & $\begin{array}{l}0,32 \\
0,44 \\
0,55\end{array}$ & $\begin{array}{l}0,29 \\
0,41 \\
0,52\end{array}$ & $\begin{array}{l}0,26 \\
0,37 \\
0,49\end{array}$ & $\begin{array}{l}0,22 \\
0,33 \\
0,46\end{array}$ & $\begin{array}{l}0,18 \\
0,29 \\
0,41\end{array}$ & $\begin{array}{l}0,13 \\
0,23 \\
0,35\end{array}$ & $\begin{array}{l}0,07 \\
0,16 \\
0,27\end{array}$ & $\begin{array}{l}0,02 \\
0,08 \\
0,16\end{array}$ & $\begin{array}{l}0,001 \\
0,006 \\
0,03\end{array}$ & $\inf$ \\
\hline$P$ & $\uparrow_{n f 2}$ & 12 & 11 & 10 & 9 & 8 & 7 & 6 & 5 & 4 & 3 & 2 & 1 & nif1 \\
\hline
\end{tabular}




\section{I I c}

DISTRIBUIÇÕES DE FISHER

teste)

\begin{tabular}{|c|c|c|c|c|c|c|c|c|c|c|c|c|c|c|}
\hline$\stackrel{\mathrm{nf1}}{\longrightarrow}$ & 1 & 2 & 3 & 4 & 5 & 6 & 7 & 8 & 9 & 10 & 11 & 12 & $\mathrm{nf} 2 \downarrow$ & $\mathbf{P}$ \\
\hline 20 & $\begin{array}{l}4,14 \\
3,15 \\
2,42\end{array}$ & $\begin{array}{l}3,33 \\
2,64 \\
2,13\end{array}$ & $\begin{array}{l}3.03 \\
2,42 \\
1,98\end{array}$ & $\begin{array}{l}2,84 \\
2,29 \\
1,88\end{array}$ & $\begin{array}{l}2,70 \\
2,19 \\
1,81\end{array}$ & $\begin{array}{l}2,60 \\
2,13 \\
1,77\end{array}$ & $\begin{array}{l}2,53 \\
2,07 \\
1,73\end{array}$ & $\begin{array}{l}2,47 \\
2,03 \\
1,71\end{array}$ & $\begin{array}{l}2,42 \\
1,99 \\
1,68\end{array}$ & $\begin{array}{l}2,38 \\
1,97 \\
1,67\end{array}$ & $\begin{array}{l}2,34 \\
1,94 \\
1,65\end{array}$ & $\begin{array}{l}2,31 \\
1,92 \\
1,64\end{array}$ & 20 & $\begin{array}{c}0,1 \% \\
1 \% \\
5 \%\end{array}$ \\
\hline 25 & $\begin{array}{l}4,01 \\
3,08 \\
2,39\end{array}$ & $\begin{array}{l}3,20 \\
2,57 \\
2,10\end{array}$ & $\begin{array}{l}2,91 \\
2,35 \\
1,94\end{array}$ & $\begin{array}{l}2,72 \\
2,22 \\
1,84\end{array}$ & $\begin{array}{l}2,59 \\
2 ; 12 \\
1,77\end{array}$ & $\begin{array}{l}2,49 \\
2,06 \\
1,72\end{array}$ & $\begin{array}{l}2,42 \\
2,00 \\
1,69\end{array}$ & $\begin{array}{l}2,36 \\
1,96 \\
1,66\end{array}$ & $\begin{array}{l}2,31 \\
1,92 \\
1,64\end{array}$ & $\begin{array}{l}2,27 \\
1,89 \\
1,63\end{array}$ & $\begin{array}{l}2,23 \\
1,86 \\
1,61\end{array}$ & $\begin{array}{l}2,19 \\
1,84 \\
1,59\end{array}$ & 25 & $\begin{array}{c}0,1 \% \\
1 \% \\
5 \%\end{array}$ \\
\hline 30 & $\begin{array}{l}3,90 \\
3,04 \\
2,36\end{array}$ & $\begin{array}{l}3,10 \\
2,53 \\
2,07\end{array}$ & $\begin{array}{l}2,81 \\
2,31 \\
1,92\end{array}$ & $\begin{array}{l}2,63 \\
2,18 \\
1,81\end{array}$ & $\begin{array}{l}2,50 \\
2,08 \\
1,73\end{array}$ & $\begin{array}{l}2,40 \\
2,01 \\
1,69\end{array}$ & $\begin{array}{l}2,33 \\
1,96 \\
1,65\end{array}$ & $\begin{array}{l}2,27 \\
1,91 \\
1,62\end{array}$ & $\begin{array}{l}2,22 \\
1,87 \\
1,60\end{array}$ & $\begin{array}{l}2,18 \\
1,85 \\
1,59\end{array}$ & $\begin{array}{l}2,14 \\
1,82 \\
1,57\end{array}$ & $\begin{array}{l}2,10 \\
1,79 \\
1,55\end{array}$ & 30 & $\begin{array}{c}0,1 \% \\
1 \% \\
5 \%\end{array}$ \\
\hline 35 & $\begin{array}{l}3,82 \\
3,00 \\
2,34\end{array}$ & $\begin{array}{l}3,03 \\
2,49 \\
2,05\end{array}$ & $\begin{array}{l}2,74 \\
2,27 \\
1,90\end{array}$ & $\begin{array}{l}2,56 \\
2,14 \\
1,79\end{array}$ & $\begin{array}{l}2,43 \\
2,04 \\
1,71\end{array}$ & $\begin{array}{l}2,33 \\
1,98 \\
1,66\end{array}$ & $\begin{array}{l}2,26 \\
1,92 \\
1,63\end{array}$ & $\begin{array}{l}2,20 \\
1,88 \\
1,60\end{array}$ & $\begin{array}{l}2,15 \\
1,84 \\
1,57\end{array}$ & $\begin{array}{l}2,11 \\
1,81 \\
1,56\end{array}$ & $\begin{array}{l}2,07 \\
1,78 \\
1,54\end{array}$ & $\begin{array}{l}2,03 \\
1,75 \\
1,53\end{array}$ & 35 & $\begin{array}{c}0,1 \% \\
1 \% \\
5 \%\end{array}$ \\
\hline 40 & $\begin{array}{l}3,78 \\
2,97 \\
2,33\end{array}$ & $\begin{array}{l}2,99 \\
2,46 \\
2,04\end{array}$ & $\begin{array}{l}2,70 \\
2,24 \\
1,89\end{array}$ & $\begin{array}{l}2,52 \\
2,11 \\
1,78\end{array}$ & $\begin{array}{l}2,39 \\
2,01 \\
1,70\end{array}$ & $\begin{array}{l}2,29 \\
1,95 \\
1,65\end{array}$ & $\begin{array}{l}2,22 \\
1,89 \\
1,61\end{array}$ & $\begin{array}{l}2,16 \\
1,85 \\
1,58\end{array}$ & $\begin{array}{l}2,11 \\
1,81 \\
1,56\end{array}$ & $\begin{array}{l}2,07 \\
1,78 \\
1,55\end{array}$ & $\begin{array}{l}2,03 \\
1,75 \\
1,53\end{array}$ & $\begin{array}{l}1,99 \\
1,72 \\
1,51\end{array}$ & 40 & $\begin{array}{c}0,1 \% \\
1 \% \\
5 \%\end{array}$ \\
\hline 45 & $\begin{array}{l}3,74 \\
2,95 \\
2,33\end{array}$ & $\begin{array}{l}2,95 \\
2,44 \\
2,04\end{array}$ & $\begin{array}{l}2,66 \\
2,22 \\
1,88\end{array}$ & $\begin{array}{l}2,48 \\
2,09 \\
1,78\end{array}$ & $\begin{array}{l}2,35 \\
1,99 \\
1,70\end{array}$ & $\begin{array}{l}2,25 \\
1,92 \\
1,64\end{array}$ & $\begin{array}{l}2,18 \\
1,87 \\
1,61\end{array}$ & $\begin{array}{l}2.12 \\
1,82 \\
1,58\end{array}$ & $\begin{array}{l}2,07 \\
1,78 \\
1,55\end{array}$ & $\begin{array}{l}2,03 \\
1,75 \\
1,54\end{array}$ & $\begin{array}{l}1,99 \\
1,72 \\
1,52\end{array}$ & $\begin{array}{l}1,95 \\
1,70 \\
1,50\end{array}$ & 45 & $\begin{array}{c}0,1 \% \\
1 \% \\
5 \%\end{array}$ \\
\hline 50 & $\begin{array}{l}3,70 \\
2.93 \\
2,32\end{array}$ & $\begin{array}{l}2,91 \\
2,42 \\
2,03\end{array}$ & $\begin{array}{l}2,62 \\
2,20 \\
1,88\end{array}$ & $\begin{array}{l}2,45 \\
2,07 \\
1,77\end{array}$ & $\begin{array}{l}2,32 \\
1,97 \\
1,69\end{array}$ & $\begin{array}{l}2,22 \\
1,90 \\
1,64\end{array}$ & $\begin{array}{l}2,15 \\
1,85 \\
1,60\end{array}$ & $\begin{array}{l}2,09 \\
1,80 \\
1,57\end{array}$ & $\begin{array}{l}2,04 \\
1,76 \\
1,55\end{array}$ & $\begin{array}{l}2,00 \\
1,73 \\
1,53\end{array}$ & $\begin{array}{l}1,96 \\
1,70 \\
1,51\end{array}$ & $\begin{array}{l}1,92 \\
1,68 \\
1,49\end{array}$ & 50 & $\begin{array}{c}0,1 \% \\
1 \% \\
5 \%\end{array}$ \\
\hline 75 & $\begin{array}{l}3,61 \\
2,88 \\
2,29\end{array}$ & $\begin{array}{l}2,82 \\
2,37 \\
2,00\end{array}$ & $\begin{array}{l}2.53 \\
2.15 \\
1,85\end{array}$ & $\begin{array}{l}2,37 \\
2,02 \\
1,74\end{array}$ & $\begin{array}{l}2,24 \\
1,02 \\
1,66\end{array}$ & $\begin{array}{l}2,14 \\
1,85 \\
1,61\end{array}$ & $\begin{array}{l}2.07 \\
1.79 \\
1,57\end{array}$ & $\begin{array}{l}2,01 \\
1,74 \\
1,54\end{array}$ & $\begin{array}{l}1,96 \\
1,70 \\
1,52\end{array}$ & $\begin{array}{l}1,92 \\
1,67 \\
1,50\end{array}$ & $\begin{array}{l}1,88 \\
1,64 \\
1,48\end{array}$ & $\begin{array}{l}1,84 \\
1,62 \\
1,46\end{array}$ & 75 & $\begin{array}{c}0,1 \% \\
1 \% \\
5 \%\end{array}$ \\
\hline 100 & $\begin{array}{l}3,58 \\
2,86 \\
2,27\end{array}$ & $\begin{array}{l}2,80 \\
2,35 \\
1,98\end{array}$ & $\begin{array}{l}2,52 \\
2.13 \\
1,83\end{array}$ & $\begin{array}{l}2,34 \\
2,00 \\
1,72\end{array}$ & $\begin{array}{l}2,21 \\
1,90 \\
1,64\end{array}$ & $\begin{array}{l}2,11 \\
1,83 \\
1,59\end{array}$ & $\begin{array}{l}2,04 \\
1,77 \\
1,55\end{array}$ & $\begin{array}{l}1,98 \\
1,72 \\
1,52\end{array}$ & $\begin{array}{l}1,93 \\
1,68 \\
1,50\end{array}$ & $\begin{array}{l}1,89 \\
1,65 \\
1,48\end{array}$ & $\begin{array}{l}1,85 \\
1,62 \\
1,46\end{array}$ & $\begin{array}{l}1,81 \\
1,60 \\
1,44\end{array}$ & 100 & $\begin{array}{c}0,1 \% \\
1 \% \\
5 \%\end{array}$ \\
\hline 500 & $\begin{array}{l}3,51 \\
2,83 \\
2,25\end{array}$ & $\begin{array}{l}2,73 \\
2,32 \\
1,96\end{array}$ & $\begin{array}{l}2,47 \\
2,11 \\
1,81\end{array}$ & $\begin{array}{l}2,27 \\
1,97 \\
1,70\end{array}$ & $\begin{array}{l}2.14 \\
1,87 \\
1,62\end{array}$ & $\begin{array}{l}2,04 \\
1,80 \\
1,60\end{array}$ & $\begin{array}{l}1,97 \\
1,74 \\
1,53\end{array}$ & $\begin{array}{l}1,91 \\
1,69 \\
1,49\end{array}$ & $\begin{array}{l}1,86 \\
1,65 \\
1,47\end{array}$ & $\begin{array}{l}1,82 \\
1,62 \\
1,45\end{array}$ & $\begin{array}{l}1,78 \\
1,59 \\
1,43\end{array}$ & $\begin{array}{l}1,74 \\
1,56 \\
1,41\end{array}$ & 500 & $\begin{array}{c}0,1 \% \\
1 \% \\
5 \%\end{array}$ \\
\hline inf & $\begin{array}{l}3,48 \\
2,81 \\
2,24\end{array}$ & $\begin{array}{l}2,70 \\
2.30 \\
1,95\end{array}$ & $\begin{array}{l}2,42 \\
2,08 \\
1,80\end{array}$ & $\begin{array}{l}2,24 \\
1,95 \\
1,69\end{array}$ & $\begin{array}{l}2,11 \\
1,85 \\
1,61\end{array}$ & $\begin{array}{l}2,01 \\
1,78 \\
1,56\end{array}$ & $\begin{array}{l}1,94 \\
1,72 \\
1,52\end{array}$ & $\begin{array}{l}1,88 \\
1,67 \\
1,48\end{array}$ & $\begin{array}{l}1,83 \\
1,63 \\
1,46\end{array}$ & $\begin{array}{l}1,78 \\
1,60 \\
1,44\end{array}$ & $\begin{array}{l}1,74 \\
1,57 \\
1,42\end{array}$ & $\begin{array}{l}1,70 \\
1,54 \\
1,40\end{array}$ & inf & $\begin{array}{c}0,1 \% \\
1 \% \\
5 \%\end{array}$ \\
\hline nf 1 & 1 & 2 & 3 & 4 & 5 & 6 & 7 & 8 & 9 & 10 & 11 & 12 & $\mathrm{nf} 2$ & $P$ \\
\hline
\end{tabular}


T Â B U A

\section{LIMITES BILATERAIS DAS}

(Teta-

\begin{tabular}{|c|c|c|c|c|c|c|c|c|c|c|c|c|c|c|c|}
\hline$P$ & $\downarrow^{\mathrm{nf} 2}$ & $\inf$ & 100 & 75 & 50 & 45 & 40 & 35 & 30 & 25 & 20 & 15 & 14 & 13 & $\stackrel{\mathrm{nf} 1}{\leftarrow}$ \\
\hline $\begin{array}{r}0,1 \% \\
1 \% \\
5 \%\end{array}$ & 20 & $\begin{array}{l}0,65 \\
0,70 \\
0,76\end{array}$ & $\begin{array}{l}0,60 \\
0,67 \\
0,74\end{array}$ & $\begin{array}{l}0,59 \\
0,66 \\
0,72\end{array}$ & $\begin{array}{l}0,56 \\
0,63 \\
0,70\end{array}$ & $\begin{array}{l}0,55 \\
0,63 \\
0,70\end{array}$ & $\begin{array}{l}0,54 \\
0,61 \\
0,69\end{array}$ & $\begin{array}{l}0,53 \\
0,60 \\
0,68\end{array}$ & $\begin{array}{l}0,51 \\
0,59 \\
0,68\end{array}$ & $\begin{array}{l}0,49 \\
0,57 \\
0,66\end{array}$ & $\begin{array}{l}0,46 \\
0,55 \\
0,64\end{array}$ & $\begin{array}{l}0,41 \\
0,50 \\
0,60\end{array}$ & $\begin{array}{l}0,40 \\
0,49 \\
0,59\end{array}$ & $\begin{array}{l}0,39 \\
0,49 \\
0,58\end{array}$ & 20 \\
\hline $\begin{array}{r}0,1 \% \\
1 \% \\
5 \%\end{array}$ & 25 & $\begin{array}{l}0,68 \\
0,72 \\
0,78\end{array}$ & $\begin{array}{l}0,63 \\
0,68 \\
0,75\end{array}$ & $\begin{array}{l}0,61 \\
0,68 \\
0,74\end{array}$ & $\begin{array}{l}0,58 \\
0,65 \\
0,72\end{array}$ & $\begin{array}{l}0,57 \\
0,64 \\
0,71\end{array}$ & $\begin{array}{l}0,56 \\
0,63 \\
0,71\end{array}$ & $\begin{array}{l}0,55 \\
0,62 \\
0,69\end{array}$ & $\begin{array}{l}0,53 \\
0,60 \\
0,68\end{array}$ & $\begin{array}{l}0,50 \\
0,58 \\
0,67\end{array}$ & $\begin{array}{l}0,47 \\
0,56 \\
0,65\end{array}$ & $\begin{array}{l}0,42 \\
0,51 \\
0,61\end{array}$ & $\begin{array}{l}0,41 \\
0,50 \\
0,60\end{array}$ & $\begin{array}{l}0,40 \\
0,49 \\
0,59\end{array}$ & 25 \\
\hline $\begin{array}{r}0,1 \% \\
1 \% \\
5 \%\end{array}$ & 30 & $\begin{array}{l}0,70 \\
0,74 \\
0,80\end{array}$ & $\begin{array}{l}0,64 \\
0,69 \\
0,77\end{array}$ & $\begin{array}{l}0,63 \\
0,68 \\
0,76\end{array}$ & $\begin{array}{l}0,59 \\
0,66 \\
0,73\end{array}$ & $\begin{array}{l}0,58 \\
0,65 \\
0,72\end{array}$ & $\begin{array}{l}0,57 \\
0,64 \\
0,72\end{array}$ & $\begin{array}{l}0,56 \\
0,62 \\
0,70\end{array}$ & $\begin{array}{l}0,53 \\
0,61 \\
0,69\end{array}$ & $\begin{array}{l}0,51 \\
0,59 \\
0,68\end{array}$ & $\begin{array}{l}0,48 \\
0,56 \\
0,65\end{array}$ & $\begin{array}{l}0,42 \\
0,51 \\
0,61\end{array}$ & $\begin{array}{l}0,41 \\
0,51 \\
0,60\end{array}$ & $\begin{array}{l}0,40 \\
0,50 \\
0,59\end{array}$ & 30 \\
\hline $\begin{array}{r}0,1 \% \\
1 \% \\
5 \%\end{array}$ & 35 & $\begin{array}{l}0,71 \\
0,75 \\
0,81\end{array}$ & $\begin{array}{l}0,65 \\
0,70 \\
0,78\end{array}$ & $\begin{array}{l}0,64 \\
0,69 \\
0,76\end{array}$ & $\begin{array}{l}0,60 \\
0,67 \\
0,74\end{array}$ & $\begin{array}{l}0,59 \\
0,66 \\
0,74\end{array}$ & $\begin{array}{l}0,58 \\
0,65 \\
0,72\end{array}$ & $\begin{array}{l}0,56 \\
0,63 \\
0,71\end{array}$ & $\begin{array}{l}0,54 \\
0,61 \\
0,70\end{array}$ & $\begin{array}{l}0,51 \\
0,59 \\
0,68\end{array}$ & $\begin{array}{l}0,48 \\
0,56 \\
0,6 \tilde{5}\end{array}$ & $\begin{array}{l}0,43 \\
0,51 \\
0,61\end{array}$ & $\begin{array}{l}0,42 \\
0,51 \\
0,60\end{array}$ & $\begin{array}{l}0,40 \\
0,50 \\
0,60\end{array}$ & 35 \\
\hline $\begin{array}{r}0,1 \% \\
1 \% \\
5 \%\end{array}$ & 40 & $\begin{array}{l}0,73 \\
0,77 \\
0,81\end{array}$ & $\begin{array}{l}0,66 \\
0,71 \\
0,78\end{array}$ & $\begin{array}{l}0,65 \\
0,70 \\
0,77\end{array}$ & $\begin{array}{l}0,61 \\
0,67 \\
0,75\end{array}$ & $\begin{array}{l}0,60 \\
0,66 \\
0,74\end{array}$ & $\begin{array}{l}0,58 \\
0,65 \\
0,73\end{array}$ & $\begin{array}{l}0,57 \\
0,63 \\
0,72\end{array}$ & $\begin{array}{l}0,55 \\
0,62 \\
0,70\end{array}$ & $\begin{array}{l}0,52 \\
0,60 \\
0,68\end{array}$ & $\begin{array}{l}0,49 \\
0,57 \\
0,66\end{array}$ & $\begin{array}{l}0,53 \\
0,52 \\
0,62\end{array}$ & $\begin{array}{l}0,42 \\
0,51 \\
0,61\end{array}$ & $\begin{array}{l}0,41 \\
0,50 \\
0,60\end{array}$ & 40 \\
\hline $\begin{array}{r}0,1 \% \\
1 \% \\
5 \%\end{array}$ & 45 & $\begin{array}{l}0,74 \\
0,78 \\
0,82\end{array}$ & $\begin{array}{l}0,67 \\
0,72 \\
0,79\end{array}$ & $\begin{array}{l}0,65 \\
0,71 \\
0,78\end{array}$ & $\begin{array}{l}0,61 \\
0,68 \\
0,75\end{array}$ & $\begin{array}{l}0,60 \\
0,67 \\
0,74\end{array}$ & $\begin{array}{l}0,59 \\
0,66 \\
0,74\end{array}$ & $\begin{array}{l}0,57 \\
0,64 \\
0,72\end{array}$ & $\begin{array}{l}0,55 \\
0,62 \\
0,71\end{array}$ & $\begin{array}{l}0,52 \\
0,60 \\
0,68\end{array}$ & $\begin{array}{l}0,49 \\
0,57 \\
0,66\end{array}$ & $\begin{array}{l}0,43 \\
0,52 \\
0,62\end{array}$ & $\begin{array}{l}0,42 \\
0,51 \\
0,61\end{array}$ & $\begin{array}{l}0,41 \\
0,51 \\
0,60\end{array}$ & 45 \\
\hline $\begin{array}{r}0,1 \% \\
1 \% \\
5 \%\end{array}$ & 50 & $\begin{array}{l}0,75 \\
0,79 \\
0,82\end{array}$ & $\begin{array}{l}0,68 \\
0,74 \\
0,79\end{array}$ & $\begin{array}{l}0,65 \\
0,72 \\
0,78\end{array}$ & $\begin{array}{l}0,62 \\
0,69 \\
0,75\end{array}$ & $\begin{array}{l}0,61 \\
0,68 \\
0,75\end{array}$ & $\begin{array}{l}0,59 \\
0,66 \\
0,74\end{array}$ & $\begin{array}{l}0,58 \\
0,65 \\
0,72\end{array}$ & $\begin{array}{l}0,56 \\
0,63 \\
0,71\end{array}$ & $\begin{array}{l}0,52 \\
0,61 \\
0,69\end{array}$ & $\begin{array}{l}0,49 \\
0,58 \\
0,66\end{array}$ & $\begin{array}{l}0,43 \\
0,52 \\
0,62\end{array}$ & $\begin{array}{l}0,43 \\
0,51 \\
0,61\end{array}$ & $\begin{array}{l}0,41 \\
0,51 \\
0,(10)\end{array}$ & 50 \\
\hline $\begin{array}{r}0,1 \% \\
1 \% \\
5 \%\end{array}$ & 75 & $\begin{array}{l}0,79 \\
0,83 \\
0,86\end{array}$ & $\begin{array}{l}0,70 \\
0,76 \\
0,81\end{array}$ & $\begin{array}{l}0,68 \\
0,74 \\
0,79\end{array}$ & $\begin{array}{l}0,64 \\
0,71 \\
0,76\end{array}$ & $\begin{array}{l}0,62 \\
0,69 \\
0,76\end{array}$ & $\begin{array}{l}0,61 \\
0,68 \\
0,75\end{array}$ & $\begin{array}{l}0,59 \\
0,67 \\
0,73\end{array}$ & $\begin{array}{l}0,56 \\
0,65 \\
0,72\end{array}$ & $\begin{array}{l}0,53 \\
0,62 \\
0,69\end{array}$ & $\begin{array}{l}0,50 \\
0,60 \\
0,67\end{array}$ & $\begin{array}{l}0,44 \\
0,53 \\
0,63\end{array}$ & $\begin{array}{l}0,43 \\
0,52 \\
0,61\end{array}$ & $\begin{array}{l}0,41 \\
0,51 \\
0,61\end{array}$ & 75 \\
\hline $\begin{array}{r}0,1 \% \\
1 \% \\
5 \%\end{array}$ & 100 & $\begin{array}{l}0,81 \\
0,85 \\
0,88\end{array}$ & $\begin{array}{l}0,71 \\
0,77 \\
0,81\end{array}$ & $\begin{array}{l}0,68 \\
0,76 \\
0,79\end{array}$ & $\begin{array}{l}0,65 \\
0,72 \\
0,77\end{array}$ & $\begin{array}{l}0,64 \\
0,70 \\
0,76\end{array}$ & $\begin{array}{l}0,62 \\
0,69 \\
0,75\end{array}$ & $\begin{array}{l}0,60 \\
0,68 \\
0,7 \pm\end{array}$ & $\begin{array}{l}0,57 \\
0,65 \\
0,72\end{array}$ & $\begin{array}{l}0,54 \\
0,63 \\
0,70\end{array}$ & $\begin{array}{l}0,50 \\
0,60 \\
0,67\end{array}$ & $\begin{array}{l}0,44 \\
0,53 \\
0,63\end{array}$ & $\begin{array}{l}0,43 \\
0,52 \\
0,62\end{array}$ & $\begin{array}{l}0,42 \\
0,51 \\
0,61\end{array}$ & 100 \\
\hline $\begin{array}{r}0,1 \% \\
1 \% \\
5 \%\end{array}$ & 500 & $\begin{array}{l}0,91 \\
0,93 \\
0,95\end{array}$ & $\begin{array}{l}0,76 \\
0,81 \\
0,86\end{array}$ & $\begin{array}{l}0,74 \\
0,79 \\
0,84\end{array}$ & $\begin{array}{l}0,68 \\
0,76 \\
0,81\end{array}$ & $\begin{array}{l}0,65 \\
0,71 \\
0,77\end{array}$ & $\begin{array}{l}0,63 \\
0,70 \\
0,77\end{array}$ & $\begin{array}{l}0,61 \\
0,69 \\
0,75\end{array}$ & $\begin{array}{l}0,58 \\
0,66 \\
0,73\end{array}$ & $\begin{array}{l}0,54 \\
0,63 \\
0,71\end{array}$ & $\begin{array}{l}0,51 \\
0,60 \\
0,67\end{array}$ & $\begin{array}{l}0,45 \\
0,54 \\
0,63\end{array}$ & $\begin{array}{l}0,44 \\
0,54 \\
0,62\end{array}$ & $\begin{array}{l}0,42 \\
0,52 \\
0,61\end{array}$ & 500 \\
\hline $\begin{array}{r}0,1 \% \\
1 \% \\
5 \%\end{array}$ & $\inf$ & $\begin{array}{l}1,00 \\
1,00 \\
1,00\end{array}$ & $\begin{array}{l}0,77 \\
0,82 \\
0,86\end{array}$ & $\begin{array}{l}0,74 \\
0,80 \\
0,84\end{array}$ & $\begin{array}{l}0,66 \\
0,76 \\
0,81\end{array}$ & $\begin{array}{l}0,65 \\
0,72 \\
0,78\end{array}$ & $\begin{array}{l}0,63 \\
0,71 \\
0,78\end{array}$ & $\begin{array}{l}0,61 \\
0,69 \\
0,75\end{array}$ & $\begin{array}{l}0,58 \\
0,67 \\
0,74\end{array}$ & $\begin{array}{l}0,54 \\
0,63 \\
0,71\end{array}$ & $\begin{array}{l}0,51 \\
0,60 \\
0,68\end{array}$ & $\begin{array}{l}0,45 \\
0,54 \\
0,63\end{array}$ & $\begin{array}{l}0,44 \\
0,54 \\
0,62\end{array}$ & $\begin{array}{l}0,42 \\
0,52 \\
0,61\end{array}$ & $\inf$ \\
\hline$P$ & $\uparrow_{\mathrm{nf} 2}$ & $\inf$ & 100 & 75 & 50 & 45 & 40 & 35 & 30 & 25 & 201 & 15 & 14 & 13 & $\leftarrow$ \\
\hline
\end{tabular}




\section{I d}

ISTRIBUIÇÕES DE FISHER

este)

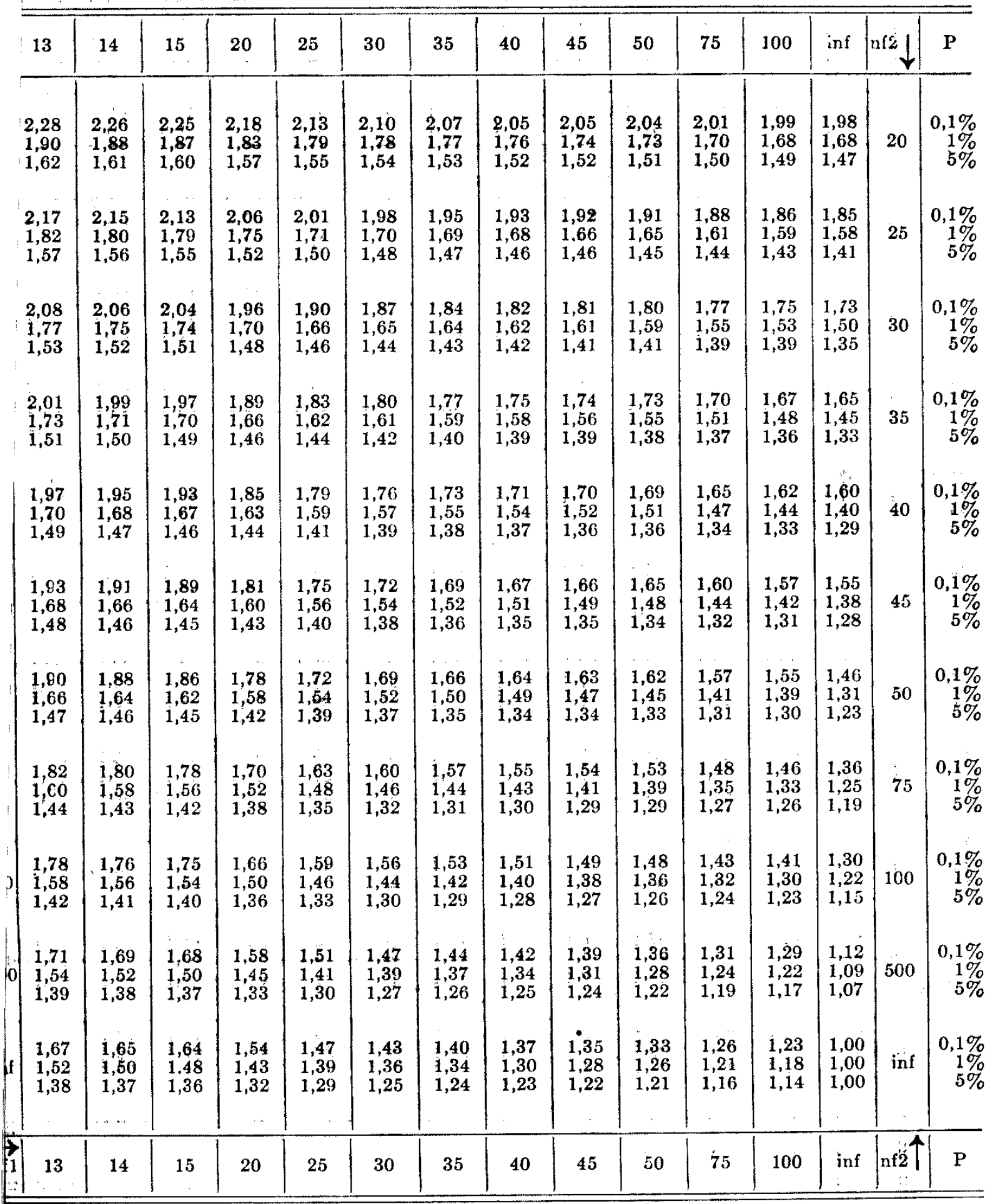




\begin{tabular}{|c|c|c|c|c|c|c|c|c|c|c|c|}
\hline A & $\because-10$ & 0 & 0 & 70 & $0 \rightarrow-10$ & ${ }_{0}^{-10}$ & 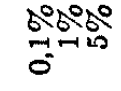 & $0=18$ & $=-70$ & $0+\infty$ & \\
\hline $\overrightarrow{\mathbb{\Xi}}$ & 용 & $\stackrel{2}{R}$ & \& & 品 & : & \& & 品 & 암 & 8 & $\ddot{\Xi}$ & \\
\hline. & 뱊에 & 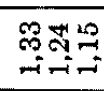 & 番禺: & 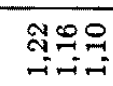 & $\stackrel{\infty}{2} \approx 88$ & tyo & ఖ8: & 700 & 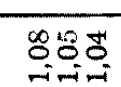 & 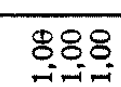 & \\
\hline 。 & 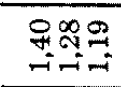 & 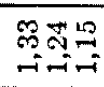 & 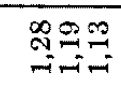 & $\begin{array}{l}\text { 전유 } \\
\text { - }\end{array}$ & 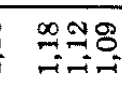 & $\begin{array}{l}:=\infty \\
\Rightarrow=-i\end{array}$ & 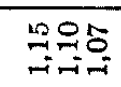 & 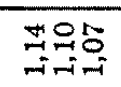 & $\underset{7}{7080}$ & S: & \\
\hline 윰 & 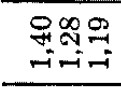 & 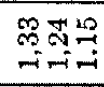 & 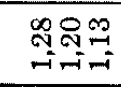 & 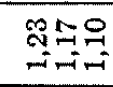 & $\stackrel{9}{298}$ & $\begin{array}{l}7 \approx 8 \\
-7=-1\end{array}$ & \begin{tabular}{l}
$0=\infty$ \\
\hdashline$=0$
\end{tabular} & 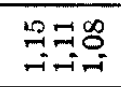 & P85 & $O_{-i=18}^{80}$ & \\
\hline 8 & Fiag & 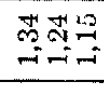 & 赵赵= & $\begin{array}{l}4 \\
-3=0\end{array}$ & 영요 & $\begin{array}{l}\infty \approx 8 \\
7\end{array}$ & $\begin{array}{l}\Rightarrow \approx 0 \\
\Rightarrow \approx-0\end{array}$ & $\begin{array}{l}0: \infty \\
\because=-1\end{array}$ & 웅요 & $\begin{array}{l}708 \\
7=-7\end{array}$ & \\
\hline ৪ & 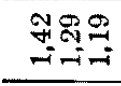 & 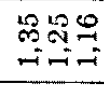 & 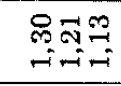 & $\begin{array}{l}2 \\
\text { An } \\
-1\end{array}$ & 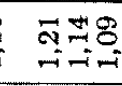 & 98 & $\stackrel{\infty}{*} \approx 0 \infty$ & 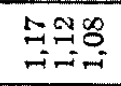 & 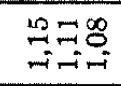 & 7888 & \\
\hline \&્ఠ & 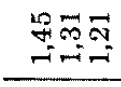 & 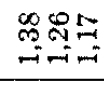 & 赵: & 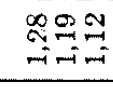 & 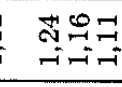 & \$2: & 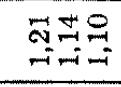 & 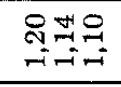 & \begin{tabular}{l}
$\infty$ \\
0 \\
\hdashline-7
\end{tabular} & $\begin{array}{l}2:=8 \\
-1\end{array}$ & \\
\hline 品 & 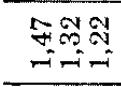 & 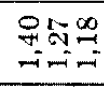 & 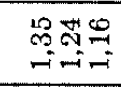 & $\begin{array}{l}8009 \\
8 \\
-17\end{array}$ & 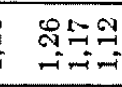 & 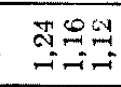 & 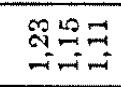 & สิเ2 & 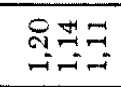 & $\begin{array}{l}1 \\
\Rightarrow=18 \\
-17\end{array}$ & \\
\hline 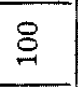 & 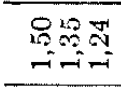 & $\begin{array}{l}\infty 080 \\
0 \\
-1 \rightarrow-7\end{array}$ & 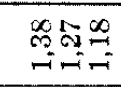 & 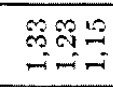 & 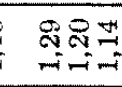 & 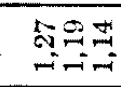 & 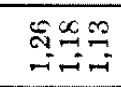 & 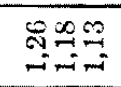 & 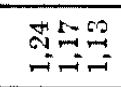 & 胥: & \\
\hline is & 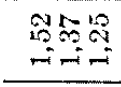 & 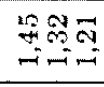 & 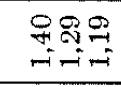 & 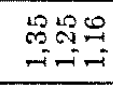 & $\underset{T \rightarrow=1}{m}$ & $\underset{-19}{8}$ & 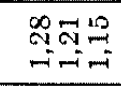 & 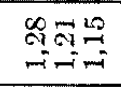 & 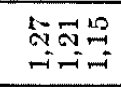 & 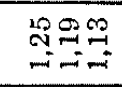 & \\
\hline 옴 & 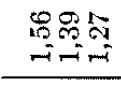 & 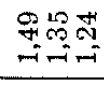 & 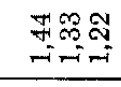 & 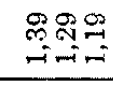 & 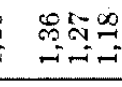 & 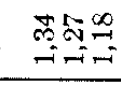 & $\operatorname{sig}_{-10}^{\infty}$ & $\operatorname{mis}_{i \rightarrow-\infty}^{\infty}$ & 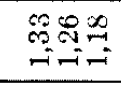 & 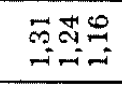 & \\
\hline $\bar{\Xi} \downarrow$ & 8 & 19 & 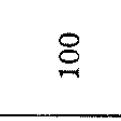 & 品 & : & : & 呆 & 움 & : & $\ddot{\sharp}$ & \\
\hline 용 & $\begin{array}{l}\text { THNR } \\
0.00 \\
0000\end{array}$ & 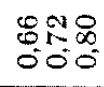 & $\begin{array}{r}0 \\
0 \\
0 \\
0 \\
0\end{array}$ & $\begin{array}{l}000 \\
000 \\
000 \\
000\end{array}$ & $\begin{array}{l}8,0 \% 0 \\
80.00 \\
000\end{array}$ & 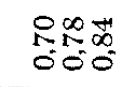 & 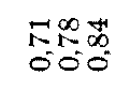 & 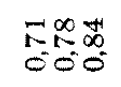 & $\begin{array}{l}F_{0}^{\infty}+0 \\
000 \\
000\end{array}$ & 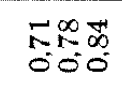 & \\
\hline R & $\begin{array}{l}0.00 \\
0,00 \\
000\end{array}$ & $\begin{array}{r}80 \% \\
80.0 \\
000 \\
000\end{array}$ & $\begin{array}{l}\text { RNo } \\
\text { RN } \\
000\end{array}$ & 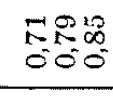 & $\begin{array}{l}N 8: 0 \\
0.00 \\
000\end{array}$ & $\begin{array}{l}100 \\
0.00 \\
0,00\end{array}$ & $\begin{array}{l}18-50 \\
0.00 \\
000 \\
0\end{array}$ & 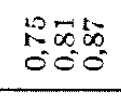 & $\begin{array}{l}10-50 \\
0.00 \\
0 \\
0 \\
0\end{array}$ & 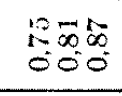 & \\
\hline 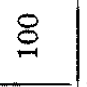 & $\begin{array}{l}8100 \\
0100 \\
000\end{array}$ & 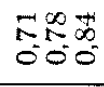 & 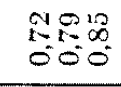 & $\begin{array}{l}\pi-\infty \\
000 \\
000\end{array}$ & $\begin{array}{l}10-0 \\
0.00 \\
000\end{array}$ & 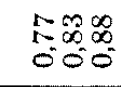 & $\begin{array}{l}\infty \infty \infty \\
\infty \\
0 \\
0 \\
0\end{array}$ & $\begin{array}{l}\infty \infty \infty \\
\infty \\
\infty \\
0 \\
0 \\
0\end{array}$ & $\begin{array}{l}\infty \\
x+\infty \\
0+\infty \\
-\infty, 00\end{array}$ & $\begin{array}{l}\infty+\infty \\
\infty \\
100 \\
0 \\
0\end{array}$ & \\
\hline 昌 & 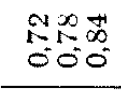 & $\begin{array}{l}5 \infty 20 \\
500 \\
0 \\
0\end{array}$ & $\begin{array}{l}18-5 \times 0 \\
800 \\
000 \\
000\end{array}$ & 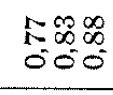 & $\begin{array}{l}\infty \\
0 \\
0 \\
0 \\
0 \\
0\end{array}$ & $\begin{array}{l}0100 \\
0.00 \\
0,000\end{array}$ & $\begin{array}{l}500 \\
000 \\
000 \\
000\end{array}$ & 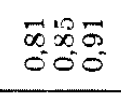 & $\begin{array}{l}000 \\
000 \\
000 \\
000\end{array}$ & $\begin{array}{l}\infty 000 \\
000 \\
000\end{array}$ & 음 \\
\hline \&్సి & 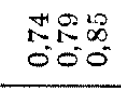 & $\begin{array}{l}0-10 \\
0.00 \\
0 \\
0\end{array}$ & 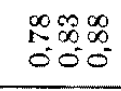 & $\begin{array}{l}9: 08 \\
0: 0 \\
0000\end{array}$ & $\begin{array}{r}-\infty \\
0 \\
0 \\
0 \\
0\end{array}$ & $\begin{array}{l}\infty \infty \infty \\
\infty \\
0 \\
0 \\
0\end{array}$ & $\begin{array}{l}\infty \infty \\
\infty \\
\infty \\
000 \\
000 \\
0\end{array}$ & 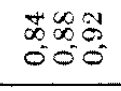 & 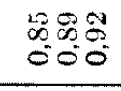 & 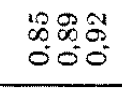 & : \\
\hline \&్ల & $\begin{array}{l}1900 \\
1000 \\
000 \\
00\end{array}$ & 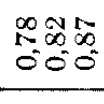 & 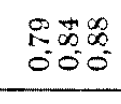 & $\begin{array}{l}0.08 \\
000 \\
000\end{array}$ & 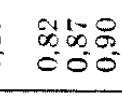 & $\begin{array}{l}+\infty \infty \\
500 \\
000 \\
0\end{array}$ & $\begin{array}{l}1000 \\
000 \\
000 \\
000\end{array}$ & $\begin{array}{l}1000 \\
0.00 \\
0000\end{array}$ & $\begin{array}{l}100.8 \\
000 \\
000\end{array}$ & $\begin{array}{l}\text { noj. } \\
\text { no. } \\
0 \\
0\end{array}$ & : \\
\hline \& & $\begin{array}{r}19010 \\
9000 \\
000 \\
000\end{array}$ & 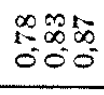 & 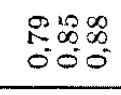 & $\begin{array}{l}50 \times 0 \\
0,00 \\
000\end{array}$ & $\begin{array}{l}\infty \\
\infty \\
\infty \\
\infty \\
0 \\
0 \\
0\end{array}$ & $\begin{array}{r}100 \\
0 \\
0 \\
0 \\
0\end{array}$ & $\begin{array}{l}1808 \\
0.80 \\
000\end{array}$ & $\begin{array}{l}\infty 8 \% \\
0.80 \\
000\end{array}$ & 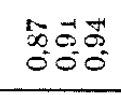 & $\begin{array}{l}801 \% \\
000 \\
000\end{array}$ & 8 \\
\hline 웅 & 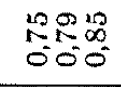 & 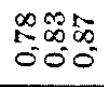 & $\begin{array}{r}0100 \\
000 \\
1000 \\
000\end{array}$ & 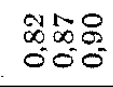 & $\begin{array}{l}\infty \\
\infty \\
\infty \\
0 \\
0.5 \\
0\end{array}$ & 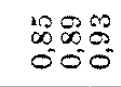 & $\begin{array}{l}1809 \\
0.80 \\
0000\end{array}$ & $\begin{array}{r}1=8 \% \\
00.80 \\
000\end{array}$ & $\begin{array}{l}\infty \\
0.00 \\
000 \\
0 \\
0\end{array}$ & $\begin{array}{l}8010 \\
8050 \\
0000\end{array}$ & ¿о \\
\hline$\stackrel{8}{0}$ & 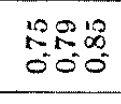 & 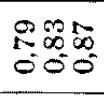 & 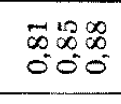 & 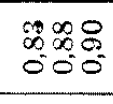 & $\begin{array}{l}100 \\
0,0 \\
0.0 \\
000 \\
000\end{array}$ & $\begin{array}{l}r 8 \infty \\
\infty \\
0.800 \\
000\end{array}$ & $\begin{array}{l}\infty 0.8 \\
0.50 \\
000\end{array}$ & $\begin{array}{l}\infty \\
\infty \\
0.8 \\
000 \\
0.00\end{array}$ & $\begin{array}{l}8000 \\
000 \\
0.00\end{array}$ & $\begin{array}{l}1218 \\
928 \\
000 \\
000\end{array}$ & 웅 \\
\hline$\overleftrightarrow{\Xi}$ & $\begin{array}{r}0,00 \\
1000 \\
000\end{array}$ & 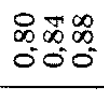 & $\begin{array}{l}\text { कt5o } \\
000 \\
000\end{array}$ & $\begin{array}{l}1080 \\
000 \\
000 \\
000\end{array}$ & $\begin{array}{r}20808 \\
0000 \\
000 \\
000\end{array}$ & $\begin{array}{l}\infty \\
\infty \\
0.00 \\
000 \\
0\end{array}$ & $\begin{array}{l}800 \\
8.00 \\
000 \\
000\end{array}$ & $\begin{array}{l}5 \% 28 \\
\text { s.5. } \\
000\end{array}$ & $\begin{array}{l}9.8 \% \\
500 \\
000 \\
\end{array}$ & 888 & $\dot{\vec{g}}$ \\
\hline$\stackrel{\Xi}{\rightarrow}$ & in & 19 & 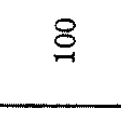 & 品 & : & : & 京 & 웅 & \& & $\dot{\Xi}$ & \\
\hline & 0 & & 0 & & & $=$ & 6 & $=7$ & 5 & 0 & \\
\hline
\end{tabular}




\begin{tabular}{|c|c|c|c|c|c|c|c|c|c|c|c|}
\hline$A_{1}$ & $\begin{array}{l}5050 \\
-10 \\
0\end{array}$ & 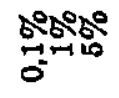 & $\begin{array}{l}5250 \\
7 \\
0\end{array}$ & $\frac{505050}{0}$ & $\frac{50200}{5}$ & ㅇำ & $\frac{50250}{0}$ & $\begin{array}{l}50250 \\
-6 \\
0\end{array}$ & 웡 & 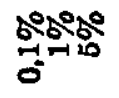 & A \\
\hline $\overrightarrow{\text { 올 }}$ & 요 & 12 & ర్ & 兽 & శ్తి & ఫ్లి & 8 & ర్ర్య & 양 & .્ّ & $\overleftarrow{4}$ \\
\hline : & 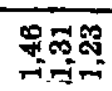 & 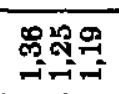 & อి & 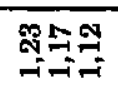 & 엻= & $12=8$ & 里웜 & 광영ㄷㅁ & 题禺 & 888 & 范 \\
\hline 8 & 赵象赵 & 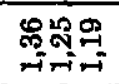 & "ైశ్ & 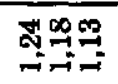 & 쵸 & 昰些 & $\begin{array}{l}= \pm=0 \\
\Rightarrow=1\end{array}$ & 电象 & $\begin{array}{l} \pm=8 \\
\pm=0\end{array}$ & 580 & ర్ర్ \\
\hline 8 & 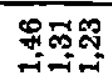 & 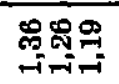 & 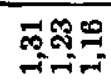 & 웍웍 & สูฐ二ี & 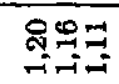 & $\begin{array}{l}\infty 100 \\
212 \\
\Rightarrow=1\end{array}$ & $\begin{array}{l}= \\
= \\
=\end{array}$ & 电 & 980 & 8 \\
\hline 윰 & 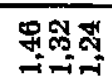 & ๓ొన్స్స్ & 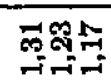 & 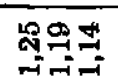 & สูง & 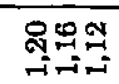 & 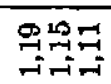 & 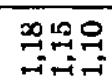 & 욕욕 & 영요요 & ᄋ్ \\
\hline ఫ్లి & 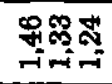 & 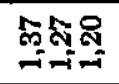 & 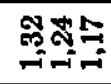 & 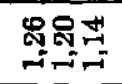 & 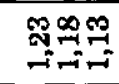 & ت气 & 怘里 & $\begin{array}{l}90 \\
\text { 욜 }\end{array}$ & 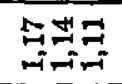 & 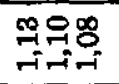 & 8 \\
\hline ఫ్ڤి & W & 웤점저 & 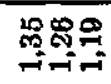 & 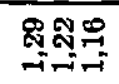 & ถูสిశ్ & Nㅕㅍ & 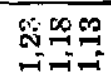 & $\underset{-12}{\mathbb{N}}$ & 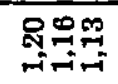 & $\begin{array}{l}9=0 \\
\text { = }\end{array}$ & 옹 \\
\hline ำ & 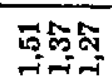 & 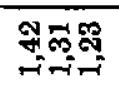 & 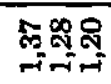 & 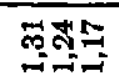 & 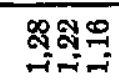 & สุลี & 성연 & 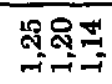 & 悉先 & 量然 & మి \\
\hline 8 & 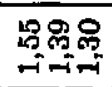 & \%禺哭 & =요 & מำ శึ워 & 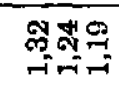 & 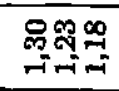 & 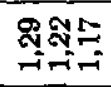 & 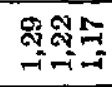 & 첣춰 & 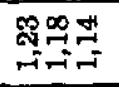 & $\underset{ㅇ}{8}$ \\
\hline 12 & 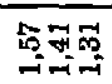 & 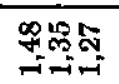 & 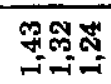 & 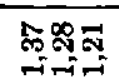 & 䒫总品 & 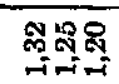 & 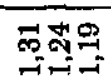 & 보요 & 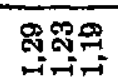 & 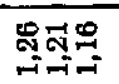 & $\stackrel{2 n}{n}$ \\
\hline 요 & 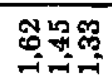 & 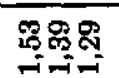 & 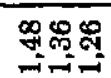 & 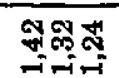 & 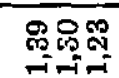 & 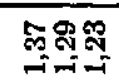 & 承蛋 & 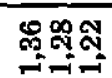 & 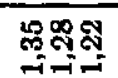 & m్ & 8 \\
\hline$=\uparrow$ & 8 & $\mathbb{2 0}$ & 8 & 옥 & \&્సి & $\stackrel{8}{\circ}$ & 8 & 웅 & ᄋ & 节 & 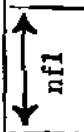 \\
\hline 용 & $\begin{array}{l}2819 \\
080 \\
000\end{array}$ & 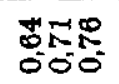 & $\begin{array}{l}\text { N. } \\
0.50 \\
000\end{array}$ & $\begin{array}{l}\text { 요요 } \\
000 \\
000\end{array}$ & 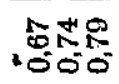 & $\begin{array}{l}\infty 120 \\
000 \\
000 \\
000\end{array}$ & $\begin{array}{l}\infty 0 \% \\
0 \%: 0 \\
000\end{array}$ & $\begin{array}{l}\infty 00 \\
0 \% 0 \\
000\end{array}$ & $\begin{array}{l}\text { Dof } \\
0 \% 0 \\
000 \\
000\end{array}$ & $\begin{array}{l}\infty e 0 \\
0<0 \\
0=0\end{array}$ & 8 \\
\hline$\stackrel{20}{2}$ & 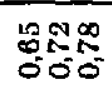 & $\begin{array}{l}\infty N D \\
0 N \\
005\end{array}$ & $\begin{array}{l}\text { DR\% } \\
0 \% \\
000\end{array}$ & $\begin{array}{l}R R=- \\
0=0 \\
000\end{array}$ & $\begin{array}{l}-1 \infty \\
\text { Non } \\
0 \\
0\end{array}$ & 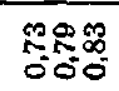 & $\begin{array}{l}+10 \% \\
0.50 \\
000\end{array}$ & 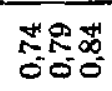 & 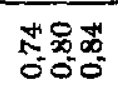 & 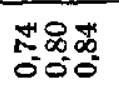 & 2 \\
\hline 8 & $\begin{array}{l}\text { DNR } \\
\text { Nㅗㅇ } \\
0000\end{array}$ & 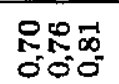 & $\begin{array}{l}\hat{k N \infty} \\
000\end{array}$ & 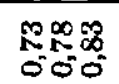 & 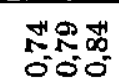 & $\begin{array}{l}0=10 \\
0.00 \\
000\end{array}$ & $\begin{array}{l}0=\infty \\
R \infty \infty \\
0=0\end{array}$ & $\begin{array}{l}0 \% \infty \\
000 \\
000\end{array}$ & $\begin{array}{l}0 \% 0 \\
0 \infty \infty \\
0 \\
0\end{array}$ & 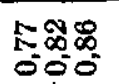 & ర్ \\
\hline$\stackrel{\circ}{\stackrel{\circ}{10}}$ & $\begin{array}{l}\text { 요요 } \\
000 \\
000\end{array}$ & 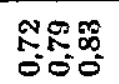 & 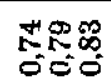 & $\begin{array}{l}000 \\
000 \\
0=0\end{array}$ & $\begin{array}{l}\infty \\
5 \infty \\
500 \\
0\end{array}$ & 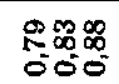 & 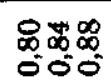 & $\begin{array}{l}\infty \\
\infty \\
\infty \\
0 \\
0 \\
0\end{array}$ & $\begin{array}{l}-10 \infty \\
\infty \infty \infty \\
000 \\
0 \\
0\end{array}$ & $\begin{array}{l}-10 \infty \\
\infty \\
000 \\
000\end{array}$ & 总 \\
\hline ళ్ & 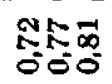 & 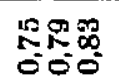 & 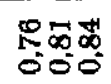 & $\begin{array}{l}\infty \mathscr{\infty} \\
100 \\
0 \\
0\end{array}$ & 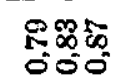 & $\begin{array}{l}-10 \\
0 \\
0 \\
000 \\
000\end{array}$ & 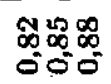 & $\begin{array}{l}100 \\
\infty \infty 0 \\
000 \\
0\end{array}$ & 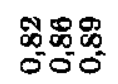 & $\begin{array}{l}5 \infty \\
5 \infty \\
000 \\
000\end{array}$ & ళ్రి \\
\hline \&్ల & 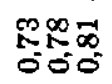 & $\begin{array}{l}080 \\
0 \times 0 \\
000\end{array}$ & $\begin{array}{l}\hat{T} \times \infty \\
0 \\
0\end{array}$ & 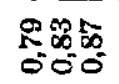 & 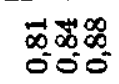 & $\begin{array}{l}1008 \\
000 \\
000 \\
000\end{array}$ & 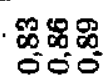 & 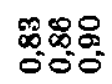 & 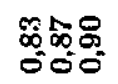 & $\begin{array}{l}500 \\
\infty \\
000 \\
000\end{array}$ & ८్లి \\
\hline 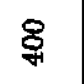 & \begin{tabular}{l}
$+\infty \infty$ \\
\multirow{2}{*}{$=0$} \\
00
\end{tabular} & 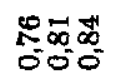 & $\begin{array}{l}\infty \\
\infty \\
=\infty \\
0 \\
0 \\
0\end{array}$ & 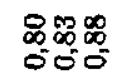 & $\begin{array}{l}-150 \\
\infty \\
0 \\
0 \\
0\end{array}$ & $\begin{array}{l}\infty \\
\infty \\
0 \\
0\end{array}$ & 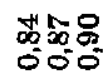 & $\begin{array}{l}\mathscr{\infty} \infty \\
0 \\
0 \\
0\end{array}$ & 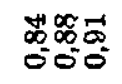 & 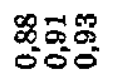 & 号 \\
\hline 8 & 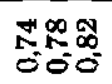 & 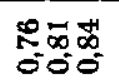 & $\begin{array}{l}\infty \\
\infty \\
0 \\
0 \\
0\end{array}$ & $\begin{array}{l}0 \\
\infty \\
\infty \\
0 \\
0 \\
0\end{array}$ & 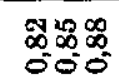 & $\begin{array}{l}H+\infty \\
0 \infty \\
000 \\
0\end{array}$ & $\begin{array}{l}2005-\infty \\
\infty \\
0 \\
0\end{array}$ & 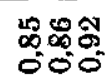 & $\begin{array}{l}\infty \\
\infty \\
0 \\
0 \\
0\end{array}$ & 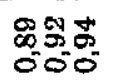 & 居 \\
\hline ఫ্ & 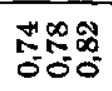 & 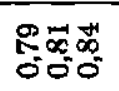 & 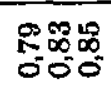 & $\begin{array}{l}-12 \infty \\
\infty \\
00 \\
0 \\
0\end{array}$ & $\begin{array}{l}\mathscr{m}_{\infty}^{\infty} \\
00 \\
00\end{array}$ & $\begin{array}{l}10 \infty \\
\infty \infty \\
0 \\
0\end{array}$ & $\begin{array}{l}\text { Do } \\
\infty \\
0 \\
0 \\
0 \\
0\end{array}$ & $\begin{array}{l}\text { ळ: } \\
\infty \\
000 \\
0\end{array}$ & 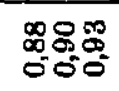 & 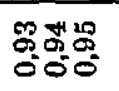 & ‡్ \\
\hline$\dot{\vec{E}}$ & $\begin{array}{l}10 \% 2 \\
150 \\
000\end{array}$ & 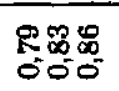 & 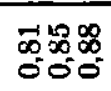 & 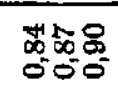 & $\begin{array}{l}\infty \infty 0 \\
0 \infty 0 \\
000\end{array}$ & 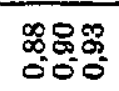 & 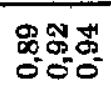 & $\begin{array}{l}\text { - } \\
\text { Sळ } \\
0\end{array}$ & 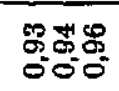 & 888 & 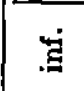 \\
\hline 祍 & 8 & $\stackrel{20}{2}$ & 8 & 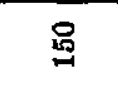 & \&్సి & ষ্ল & 유 & 8 & 8 & . & 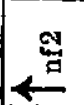 \\
\hline$A_{1}$ & $\begin{array}{l}59500 \\
= \\
=\end{array}$ & 용 & 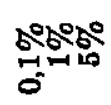 & $\begin{array}{l}\text { s050요 } \\
\frac{1}{0}\end{array}$ & 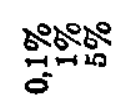 & $\begin{array}{l}5850 \\
0 \\
0\end{array}$ & ర్లో & 원요 & $\begin{array}{l}5050 \\
6 \\
0 \\
0\end{array}$ & 웡요 & A \\
\hline
\end{tabular}




\section{TÁBUA VI}

TÁBUA AUXILIAR P/ INTERPOLAÇÃO DOS LIMITES DO DESVIO RELATIVO

A

\begin{tabular}{|c|c|c|c|c|c|}
\hline \multicolumn{4}{|c|}{ VALORES DE (nx-na) PARA OS INTERVALOS : } & \multirow{2}{*}{ m } & \multirow{2}{*}{$\begin{array}{c}\text { Dif. } \\
\text { consec. }\end{array}$} \\
\hline $\mathrm{nb}-\mathrm{na}=5$ & $n b-n a=25(1)$ & $\mathrm{nb}-\mathrm{na}=50(2)$ & nb-na $=500(3)$ & & \\
\hline $\begin{array}{l}0 \\
1 \\
2 \\
3 \\
4 \\
5\end{array}$ & $\begin{array}{r}0 \\
5 \\
10 \\
15 \\
20 \\
25\end{array}$ & $\begin{array}{r}0 \\
10 \\
20 \\
30 \\
40 \\
50\end{array}$ & $\begin{array}{r}0 \\
100 \\
200 \\
300 \\
400 \\
500\end{array}$ & $\begin{array}{l}0 \\
0,37 \\
0,61 \\
0,78 \\
0,91 \\
1,00\end{array}$ & $\begin{array}{l}0,37 \\
0,24 \\
0,17 \\
0,13 \\
0,09\end{array}$ \\
\hline
\end{tabular}

B

\begin{tabular}{c|l|l}
\hline $\begin{array}{c}\text { Valores do nx-na } \\
\text { para o intervalo : } \\
\text { nb-na =400 (4) }\end{array}$ & $\mathrm{m}$ & $\begin{array}{c}\text { Dif. } \\
\text { consec. }\end{array}$ \\
\hline 0 & 0 & 0,42 \\
100 & 0,42 & 0,25 \\
200 & 0,67 & 0,20 \\
300 & 0,87 & 0,13 \\
400 & 1,00 & \\
\hline
\end{tabular}

C.

\begin{tabular}{c|c|l|c}
\hline \multicolumn{2}{c|}{$\begin{array}{c}\text { Valores de (nx-na) para } \\
\text { os intervalos : }\end{array}$} & m & $\begin{array}{c}\text { Dif. } \\
\text { consec. }\end{array}$ \\
\cline { 1 - 2 } nb-na=10 & nb-na = 100 (5) & & \\
\hline 0 & 0 & 0 & 0,21 \\
1 & 10 & 0,21 & 0,18 \\
2 & 20 & 0,37 & 0,13 \\
3 & 30 & 0,50 & 0,11 \\
4 & 40 & 0,61 & 0,09 \\
5 & 50 & 0,70 & 0,08 \\
6 & 60 & 0,78 & 0,07 \\
7 & 70 & 0,85 & 0,06 \\
8 & 80 & 0,91 & 0,05 \\
9 & 90 & 0,96 & 0,04 \\
10 & 100 & 1,00 & \\
\hline
\end{tabular}

1) Para os välores intermediários que faltam devemos usar os valores de $m$ dêste quadro e multiplicá-los com as respectivas diferenças consecutivas : para $17=15+2$ temos :
$\mathbf{m}(15)=0,78$
dif. consec. $(20)-(15)=0,13$
$\mathrm{m}(19)=0,78+0,13 \times 0,61=0,78+0,08=0,86$
$\mathrm{m}(2)=0,61$

2) Os valores de m para as unidedes são os valores de $m$ do quadro $\mathrm{C}$, multiplicados com as respectivas diferenças consecutivas do quadro $A$. Para $23=20+3$ temos :
$\mathrm{m}(20)=0,61$ dif. consec. 0,17 $\mathrm{m}(23)=0,61+0,17 \times 0,50=0,61+0,08=0,69$ $\mathrm{m}(3)=0,50$

3) Os valores de $\mathrm{m}$ para as dezenas são aquêles do quadro $\mathrm{C}$ e para as unidades, os valores do mesmo quadro $\mathrm{C}$ divididos por 10 , sempr multiplicados com as diferenças consecutivas. Para 224 $=200+20+4$ temos :

$$
\mathrm{m}(200) \underset{\mathrm{m}(224)}{=0,61}=0,61+0,17 \times(0,37+0,061) \stackrel{\mathrm{m}(20)=0,37}{=0,61+0,07327}=0, \mathrm{~m}(4)=0,061
$$

4) Os valores de $\mathrm{m}$ para as dezenas são aquêles do quadro $\mathrm{C}$ e para as unidades os valọres do mesmo quadro $\mathrm{C}$ divididos por 10 , ambos multiplicados com as diferenças consecutivas. Para $348=300+40+8$ temos :

$$
\mathrm{m}(300) \underset{\mathrm{m}(348)}{=0,87} \quad \text { dif. consec. }=0,87+0,13 \times(0,61+0,091) \stackrel{\mathrm{m}(40)}{=}=0,87+0,61 \quad \stackrel{\mathrm{m}(8)}{=}=0,091
$$

5) Os valơres de $\mathrm{m}$ para as unidades são os mesmos dêste quadro, multiplicados com as respectivas diferenças consecutivas. Para $68=60+8$ temoś:

$$
\begin{aligned}
& m(60)=0,78 \quad \text { dif. consec. }=0,07 \quad m(8)=0,91 \\
& \mathrm{~m}(68)=0,78+0,07 \times 0,91=0,78 \times 0,0637=0,84
\end{aligned}
$$


TÄBUA VII

FREQUENCIAS DA DISTRIBUIÇĀO DE GAUSS

\begin{tabular}{|c|c|c|c|c|c|}
\hline \multicolumn{2}{|c|}{ INTERVALO } & \multirow{2}{*}{ Frequência } & \multicolumn{2}{|c|}{ INTERVALO } & \multirow{2}{*}{ Frequência } \\
\hline Limites & Centro & & Limites & Centro & \\
\hline $0,0-0,1$ & 0,05 & 0,039844 & $-0,05-+0,05$ & 0,0 & 0,039894 \\
\hline $0,1-0,2$ & 0,15 & 0,039448 & $0,05-\quad 0,15$ & 0,1 & 0,039695 \\
\hline $0,2-0,3$ & 0,25 & 0,038666 & $0,15-0,25$ & 0,2 & $0,039 \quad 104$ \\
\hline $0,3-0,4$ & 0,35 & $0,037 \quad 524$ & $0,25 \sim$ & 0,3 & $0,038 \quad 140$ \\
\hline $0,4-0,5$ & 0,45 & 0,036053 & $0,35-$ & 0,4 & $0,03682 \mathrm{j}$ \\
\hline $0,5-0,6$ & 0,55 & $0,034 \quad 295$ & $0,45-$ & 0,5 & 0,035206 \\
\hline $0,6-0,7$ & 0,65 & 0,032299 & $0,55-$ & 0,6 & $0,033 \quad 323$ \\
\hline $0,7-0,8$ & 0,75 & $0,030 \quad 115$ & 0,65 & 0,7 & 0,031226 \\
\hline $0,8-0,9$ & 0,85 & $0,027 \quad 798$ & $0,75-$ & 0,8 & 0,028969 \\
\hline $0,9-1,0$ & 0,95 & 0,025407 & $0,85-\quad 0,95$ & 0,9 & 0,026609 \\
\hline $1,0-1,1$ & 1,05 & 0,022987 & $0,95-\quad 1,05$ & 1,0 & $0,024 \quad 199$ \\
\hline $1,1-1,2$ & 1,15 & 0,020594 & $1,05-$ & 1,1 & 0,021784 \\
\hline $1,2-1,3$ & 1,25 & 0,018266 & $1,15-$ & 1,2 & 0,019419 \\
\hline $1,3-1,4$ & 1,35 & $0,016 \quad 040$ & $1,25-$ & 1,3 & $0,017 \quad 137$ \\
\hline $1,4-1,5$ & 1,45 & 0,013942 & $1,35-$ & 1,4 & 0,014972 \\
\hline $1,5-1,6$ & 1,55 & 0,012001 & $1,45-$ & 1,5 & 0,012951 \\
\hline $1,6-1,7$ & 1,65 & 0,010227 & $1,55-$ & 1,6 & 0,011094 \\
\hline $1,7-1,8$ & 1,75 & 0,008628 & $1,65-$ & 1,7 & 0,009405 \\
\hline $1,8-1,9$ & 1,85 & 0,007206 & $1,75-$ & 1,8 & 0,007895 \\
\hline $1,9-2,0$ & 1,95 & 0.005959 & $1,85-\quad 1,95$ & 1,9 & 0,006562 \\
\hline $2,0-2,1$ & 2,05 & 0,004879 & $1,95-2,05$ & 2,0 & $0,005 \quad 399$ \\
\hline $2,1-2,2$ & 2,15 & 0,003955 & $2,05-$ & 2,1 & 0,004398 \\
\hline $2,2-2,3$ & 2,25 & $0,003 \quad 174$ & $2,15-$ & 2,2 & 0,003548 \\
\hline $2,3-2,4$ & 2,35 & $0,002 \quad 522$ & $2,25-$ & 2,3 & 0,002833 \\
\hline $2,4-2,5$ & 2,45 & 0,001984 & $2,35-$ & 2,4 & 0,002240 \\
\hline $2,5-2,6$ & 2,55 & $0,001 \quad 545$ & $2,45-$ & 2,5 & $0,001 \quad 753$ \\
\hline $2,6-2,7$ & 2,65 & $0,001 \quad 191$ & $2,55-$ & 2,6 & 0,001358 \\
\hline $2,7-2,8$ & 2,75 & 0,000909 & $2,65^{-}$ & 2,7 & $0,001 \quad 042$ \\
\hline $2,8-2,9$ & 2,85 & $0,000 \quad 687$ & $2,75-$ & 2,8 & 0,000791 \\
\hline $2,9-3,0$ & 2,95 & $0,000 \quad 514$ & $2,85-$ & 2,9 & 0,000595 \\
\hline $3,0-3,1$ & 3,05 & 0,000381 & $2,95-$ & 3,0 & $0,000 \quad 443$ \\
\hline $3,1-3,2$ & 3,15 & $0,000 \quad 279$ & $3,05-$ & 3,1 & $0,000 \quad 327$ \\
\hline $3,2-3,3$ & 3,25 & 0,000203 & 3,15 & 3,2 & $0,000 \quad 238$ \\
\hline $3,3-3,4$ & 3,35 & 0,000146 & $3,25-$ & 3,3 & $0,000 \quad 172$ \\
\hline $3,4-3,5$ & 3,45 & $0,000 \quad 104$ & $3,35-$ & 3,4 & $0,000 \quad 123$ \\
\hline $3,5-3,6$ & 3,55 & $0,000 \quad 073$ & $3,45-$ & 3,5 & $0,000 \quad 087$ \\
\hline $3,6-3,7$ & 3,65 & $0,000 \quad 051$ & $3,55-$ & 3,6 & 0,000061 \\
\hline $3,7-3,8$ & 3,75 & 0,000035 & $3,65-$ & 3,7 & $0,000 \quad 042$ \\
\hline $3,8-3,9$ & 3,85 & $0,000 \quad 024$ & $3,75-$ & 3,8 & $0,000 \quad 029$ \\
\hline $3,9-4,0$ & 3,95 & $0,000 \quad 016$ & $3,85-\quad 3,95$ & 3,9 & $0,000 \quad 020$ \\
\hline $4,0-4,1$ & 4,05 & $0,000 \quad 010$ & $3,95-\quad 4,05$ & 4,0 & $0,000 \quad 013$ \\
\hline $4,1-4,2$ & 4,15 & 0,000007 & $4,05-$ & 4,1 & $0,000 \quad 009$ \\
\hline $4,2-4,3$ & 4,25 & 0,000005 & $4,15-$ & 4,2 & $0,000 \quad 006$ \\
\hline $4,3-4,4$ & 4,35 & $0,000 \quad 003$ & $4,25-$ & 4,3 & $0,000 \quad 004$ \\
\hline $4,4-4,5$ & 4,45 & 0,000002 & $4,35-$ & 4,4 & $0,000 \quad 002$ \\
\hline $4,5-4,6$ & 4,55 & 0,000001 & 4,45 & 4,5 & $0,000 \quad 002$ \\
\hline $4,6-4,7$ & 4,65 & $0,000 \quad 001$ & $4,55-\quad 4,65$ & 4,6 & 0,000001 \\
\hline $4,7-4,8$ & 4,75 & 0,000001 & $4,65-\quad 4,75$ & 4,7 & 0,000001 \\
\hline \multirow{2}{*}{\multicolumn{2}{|c|}{$\underset{\text { Área da metade da curva }}{\text { (Soma) }}$}} & 0,500000 & \multirow{2}{*}{\multicolumn{2}{|c|}{$\begin{array}{l}\text { Ārea da metade da curva } \\
\text { (Soma menos metade do } \\
\text { primeiro valor). }\end{array}$}} & $\begin{array}{r}0,519947 \\
-0,019947 \\
-0,000\end{array}$ \\
\hline & & & & & $0,500 \quad 000$ \\
\hline
\end{tabular}




\section{TÁBUA VIII}

FREQUÊNCIA DA DISTRIBUIÇÃO DE GAUSS

\begin{tabular}{|c|c|c|c|}
\hline $\begin{array}{l}\text { INTERVALO } \\
1 / 4 \text { do êrro }\end{array}$ & FREQUÊNCIA & $\begin{array}{l}\text { INTERVALO } \\
1 / 2 \text { do êrro }\end{array}$ & FREQUENNCIA \\
\hline $0,0-0,25$ & 0,0988 & $0-0,5$ & 0,1916 \\
\hline $0,25-0,50$ & 0,0928 & $0,5-1,0$ & 0,1499 \\
\hline $0,50-0,75$ & 0,0819 & $1,0-1,5$ & 0,0918 \\
\hline $0,75-1,00$ & 0,0680 & $1,5-2,0$ & 0,0440 \\
\hline $1,00-1,25$ & 0,0530 & $2,0-2,5$ & 0,0165 \\
\hline $1,25-1,50$ & 0,0388 & $2,5-3,0$ & 0,0049 \\
\hline $1,50-1,75$ & 0,0267 & $3,0-3,5$ & 0,0011 \\
\hline $1,75-2,00$ & 0,0173 & $3,5-4,0$ & 0,0002 \\
\hline $2,00-2,25$ & 0,0105 & & \\
\hline $2,25-2,50$ & 0,0060 & $\begin{array}{c}\text { INTERVALO } \\
\text { uma vez o êrro }\end{array}$ & FREQUENCIA \\
\hline $2,50-2,75$ & 0,0033 & & \\
\hline $2,75-3,00$ & 0,0016 & $0-1,0$ & 0,3415 \\
\hline $3,00-3,25$ & 0,0008 & $1,0-2,0$ & 0,1358 \\
\hline $3,25-3,50$ & 0,0003 & $2,0-3,0$ & 0,0214 \\
\hline $3,50-3,75$ & 0,0001 & $3,0-4,0$ & 0,0013 \\
\hline $3,75-4,00$ & 0,0001 & & \\
\hline
\end{tabular}




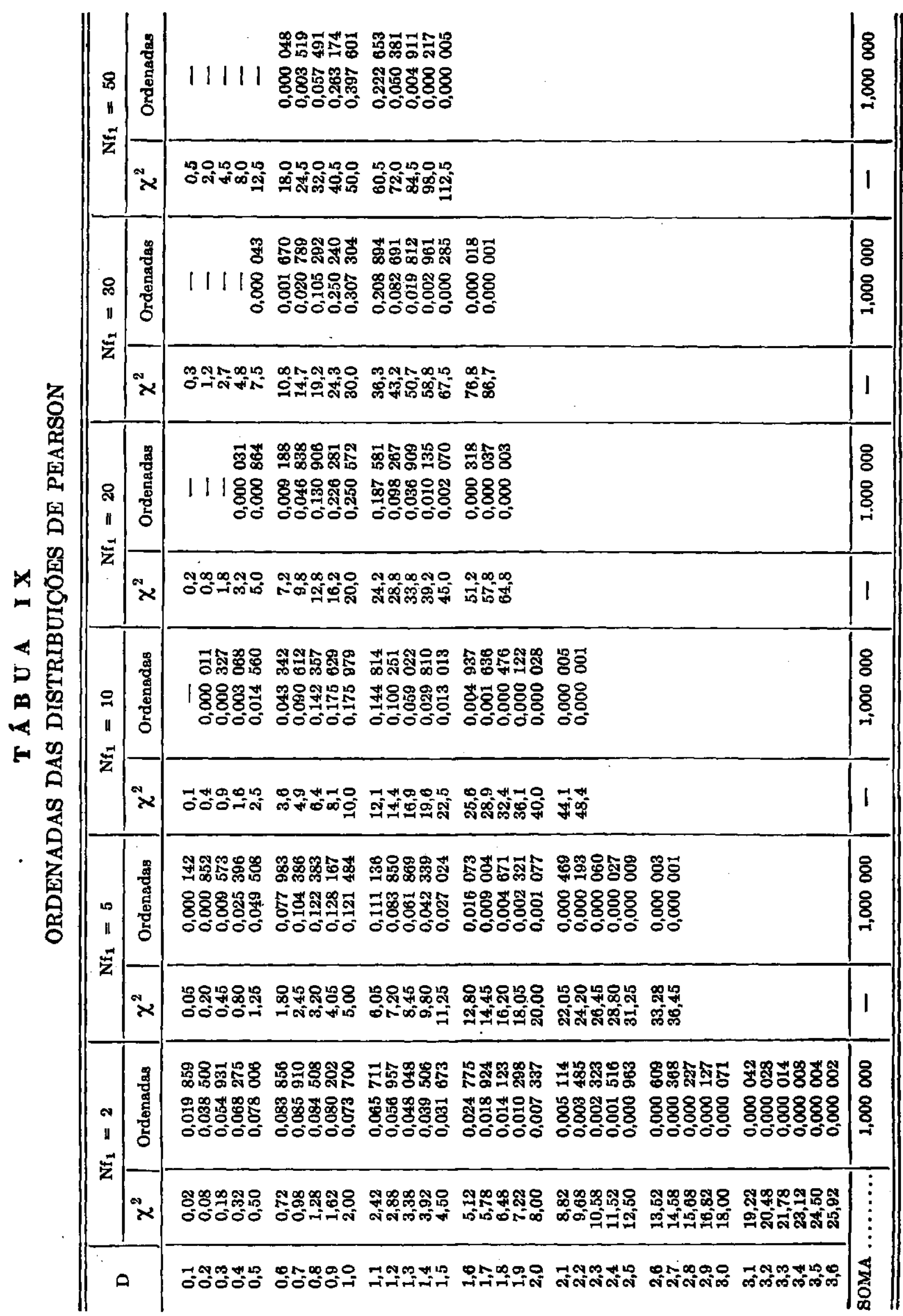




\section{TẢBUA X}

LIMITES DE $\chi^{2}$ E DO DESVIO RELATIVO (D)

NAS

DISTRIBUIÇÕ̂SS DE PEARSON

\begin{tabular}{|c|c|c|c|c|c|c|c|}
\hline \multirow{2}{*}{$n\left(x^{2}\right)$} & \multicolumn{2}{|c|}{$1 \%$} & \multicolumn{2}{|c|}{$1 \%$} & \multicolumn{2}{|c|}{$5 \%$} & \multirow{2}{*}{$\mathrm{n}\left(\chi^{2}\right)$} \\
\hline & $x^{2}$ & D & $x^{2}$ & D & $\chi^{2}$ & $\mathrm{D}$ & \\
\hline 1 & 10,83 & 3,29 & 6,66 & 2,58 & 3,84 & 1,96 & 1 \\
\hline 2 & 13,82 & 2,63 & 9,21 & 2,15 & 5,99 & 1,73 & 2 \\
\hline 3 & 16,27 & 2,33 & 11,35 & 1,95 & 7,82 & 1,61 & 3 \\
\hline 4 & 18,47 & 2,15 & 13,28 & 1,82 & 8,49 & 1,54 & 4 \\
\hline 5 & 20,52 & 2,02 & 15,09 & 1,74 & 11,07 & 1,49 & 5 \\
\hline 6 & 22,46 & 1,93 & 16,81 & 1,67 & 12,59 & 1,45 & 6 \\
\hline 7 & 24,32 & 1,86 & 18,48 & 1,62 & 14,07 & 1,42 & 7 \\
\hline 8 & 26,13 & 1,81 & 20,09 & 1,58 & 15,51 & 1,39 & 8 \\
\hline 9 & 27,88 & 1,77 & 21,67 & 1,55 & 16,92 & 1,37 & 9 \\
\hline 10 & 29,59 & 1,72 & 23,21 & 1,52 & 18,31 & 1,35 & 10 \\
\hline 11 & 31,26 & 1,69 & 24,73 & 1,50 & 19,68 & 1,34 & 11 \\
\hline 12 & 32,91 & 1,66 & 26,22 & 1,48 & 21,03 & 1,33 & 12 \\
\hline 13 & 34,53 & 1,63 & 27,69 & 1,46 & 22,36 & 1,31 & 13 \\
\hline 14 & 36,12 & 1,61 & 29,14 & 1,44 & 23,69 & 1,30 & 14 \\
\hline 15 & 37,70 & 1,59 & 30,58 & 1,43 & 25,00 & 1,29 & 15 \\
\hline 16 & 39,25 & 1,57 & 32,00 & 1,41 & 26,30 & 1,28 & 16 \\
\hline 17 & 40,79 & 1,55 & 33,41 & 1,40 & 27,59 & 1,27 & 17 \\
\hline 18 & 42,31 & 1,53 & 34,81 & 1,39 & 28,87 & 1,27 & 18 \\
\hline 19 & 43,82 & 1,52 & 36,19 & 1,38 & 30,14 & 1,26 & 19 \\
\hline 20 & 45,32 & 1,51 & 37,57 & 1,37 & 31,41 & 1,25 & 20 \\
\hline 21 & 46,80 & 1,49 & 38,93 & 1,36 & 32,67 & 1,25 & 21 \\
\hline 22 & 48,27 & 1,48 & 40,29 & 1,35 & 33,92 & 1,24 & 22 \\
\hline 23 & 49,73 & 1,47 & 41,64 & 1,35 & 35,17 & 1,24 & 23 \\
\hline 24 & 51,18 & 1,46 & 42,98 & 1,34 & 36,42 & 1,23 & 24 \\
\hline 25 & 52,62 & 1,45 & 44,31 & 1,33 & 37,65 & 1,23 & 25 \\
\hline 26 & 54,05 & 1,44 & 45,64 & 1,32 & 38,89 & 1,22 & 26 \\
\hline 27 & 55,48 & 1,43 & 46,96 & 1,32 & 40,11 & 1,22 & 27 \\
\hline 28 & 56,89 & 1,43 & 48,28 & 1,31 & 41,34 & 1,21 & 28 \\
\hline 29 & 58,30 & 1,42 & 49,59 & 1,31 & 42,56 & 1,21 & 29 \\
\hline 30 & 59,70 & 1,41 & 50,89 & 1,30 & 43,77 & 1,20 & 30 \\
\hline
\end{tabular}

Nota $:$ - Para os graus de liberdade maiores do que 30, divide-se o valor de $\chi^{2}$ achado pelo seu grau de liberdade, extraindo depois a raiz quadrada. Os limites a serem usados encontram-se nas tábuas II e IV para o desvio relativo c om $\mathrm{n} 1=\mathrm{n}\left(\chi^{2}\right)$ e $\mathrm{n}^{2}=$ infinito. 


\section{$\mathbf{T A} \mathbf{A} U \mathbf{A} \mathbf{X}$}

L I M T ES DE PRECIS A O

\begin{tabular}{|c|c|c|c|c|}
\hline \multirow{2}{*}{$\mathrm{N}$} & \multicolumn{2}{|c|}{ IIMITES CALCULADOS } & \multicolumn{2}{|c|}{ LIMITES CONVENCIONAIS } \\
\hline & Probabilidade & Improbabilidade & Probabilidäde & Improbabilidade \\
\hline 10 & $\begin{array}{l}\text { 1: } 25 \text { ou } 4 \% \\
\text { 1: } 50 \text { ou } 2 \% \\
\text { 1: } 100 \text { ou } 1 \%\end{array}$ & $\begin{array}{c}1: 50 \text { ou } 2 \% \\
1: 100 \text { ou } 1 \% \\
\text { 1: } 200 \text { ou } 0,5 \%\end{array}$ & $\begin{array}{c}1 \text { em } 20 \text { ou } \\
5 \%\end{array}$ & $\begin{array}{c}1 \text { em } 100 \text { ou } \\
1 \%\end{array}$ \\
\hline 30 & $1: 150$ ou $0,7 \%$ & $1: 300$ ou $0,3 \%$ & & \\
\hline 40 & 1: 200 ou $0,5 \%$ & 1: 400 ou $0,25 \%$ & $1 \mathrm{~cm} 100 \mathrm{ou}$ & $1 \mathrm{em} 1.000 \mathrm{ou}$ \\
\hline 50 & 1: 250 ou $0,4 \%$ & 1: 500 ou $0,2 \%$ & $1 \%$ & $0,1 \%$ \\
\hline 100 & $\begin{array}{l}1: 375 \text { ou } 0,3 \% \\
1: 500 \text { ou } 0,2 \%\end{array}$ & $\begin{array}{l}1: 750 \text { ou } 0,1 \% \\
1: 1000 \text { ou } 0,1 \%\end{array}$ & & \\
\hline $\mathrm{N}$ & $1: 5 \mathrm{~N}$ & $1: 10 \mathrm{~N}$ & - & - \\
\hline
\end{tabular}

N : Número de comparaçōes simultâneas. 